\begin{tabular}{|c|c|}
\hline 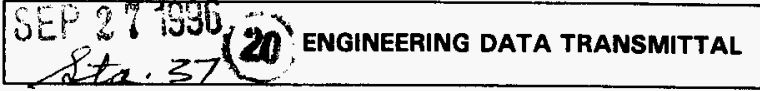 & 1. Eot $\quad 615 \frac{1}{723}$ \\
\hline
\end{tabular}

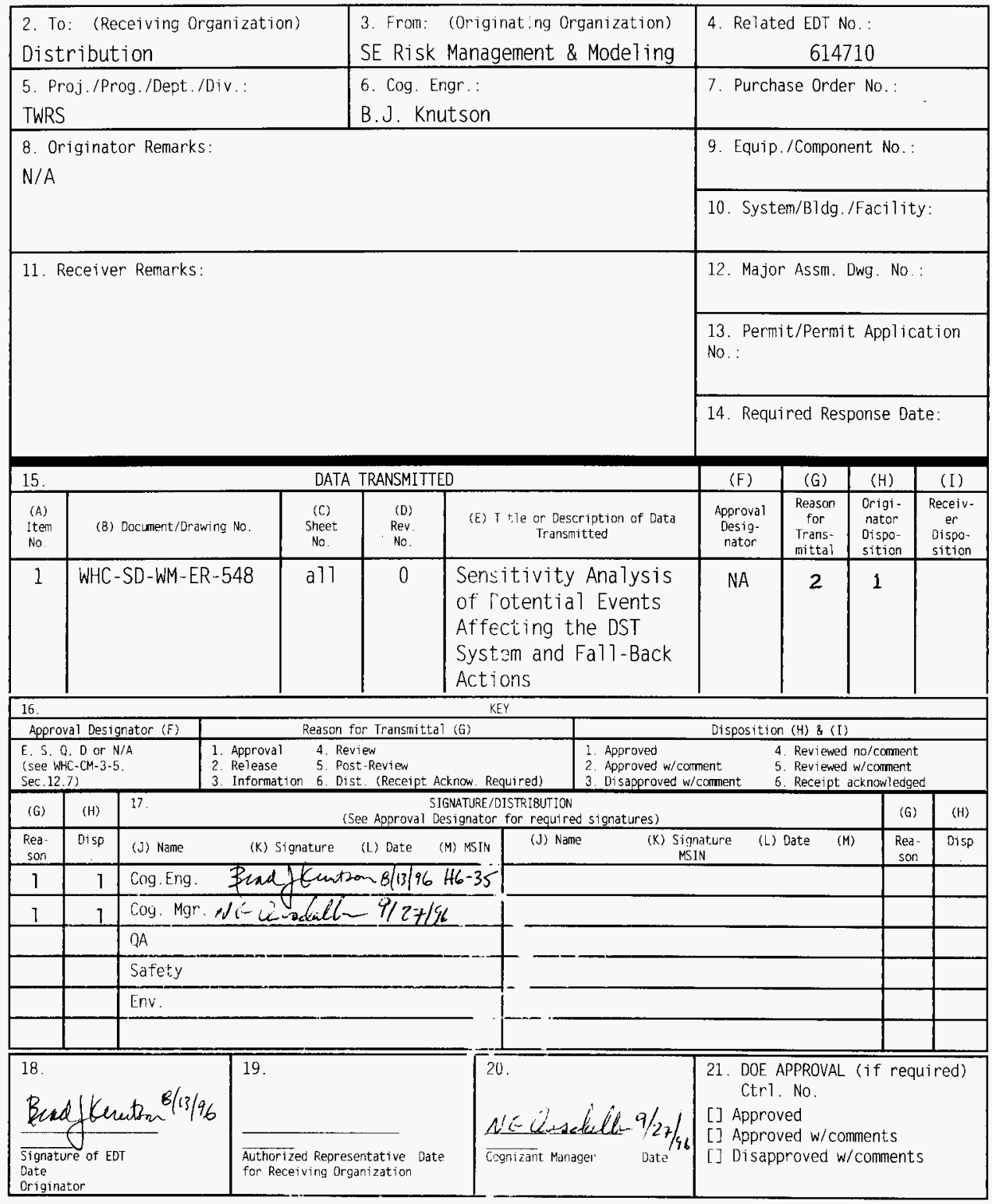




\title{
Sensitivity Analysis of Potential Events Affecting the Double-Shell Tank System and Fall-Back Actions
}

\author{
R. S. Wittman \\ G. Jansen \\ J. F. Best \\ C. E. Jensen \\ B. J. Knutson \\ B. D. Zimmerman \\ N. G. Awadalla
}

West inghouse Hanford Company, Richland, WA 99352

U.S. Department of Energy Contract DE-AC06-87RL10930

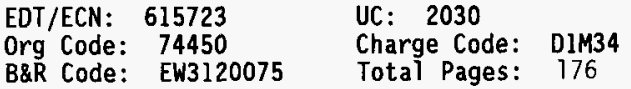

Key Words: Sensitivity, fall-back, SIMAN, DST, risk

Abstract: Sensitivity analyses were performed for fall-back positions (i.e., management actions) to accomodate potential off-normal and programatic change events overlaid on the waste volume projections and their uncertainties. This allowed determining and ranking tank system highrisk perameters and fall-back positions to accomodate associated impacts. This quantification of tank system impacts shows periods where tank capacity is sensitive to certain variables that must be carefully managed or evaluated. Identifying these sensitive variables and quantifying their impact will allow decision makers to prepare fall-back positions and focus available resources on the highest impact peramters where technical data are needed to reduce waste projection uncertainties.

TRADEMARK DISCLAIMER. Reference herein to any specific comercial product, process, or service by trade name, trademark, manufacturer, or otherwise, does not necessarily constitute or imply its endorsement, recomendation, or favoring by the United States Goverment or any agency thereof or its contractors or subcontractors.

Printed in the United States of America. To obtain copies of this document, contact: WHC/BCS Document Control Services, P.O. Box 1970, Mailstop H6-08, Richland WA 99352, Phone (509) 372-2420, Fax (509) 376-4989.
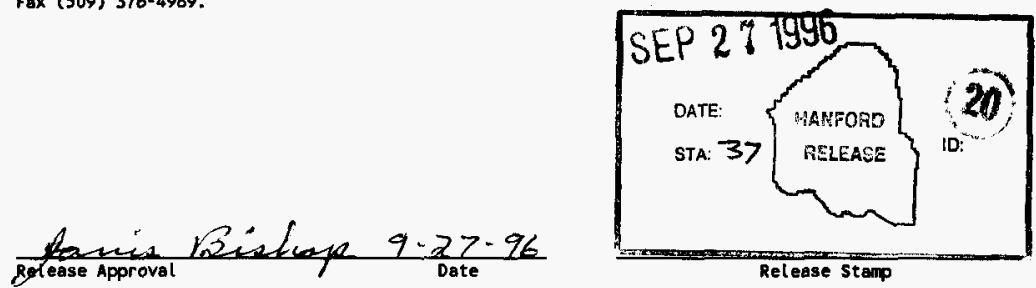


\section{Sensitivity Analysis of Potential Events Affecting the Double-Shell Tank System and Fall-Back Actions}

R.S. Wittman

G. Jansen

J.F. Best

C.E. Jensen

B.J. Knutson

B.D. Zimmerman

N.G. Awadalla

Date Published

September 1996

Prepared for the U.S. Department of Energy Office of Environmental Management

Office of Technology Development

\footnotetext{
(v) Westinghouse

Hanford Company R.O. Box 1970

Hanford Operations and Engineering Contactor for the

US. Department of Energy under Contract DE-AC06-87RL10930
}

Approved for Public Release 


\section{SENSITIVITY ANALYSIS OF POTENTIAL EVENTS AFFECTING \\ THE DOUBLE-SHELL TANK SYSTEM AND FALL-BACK ACTIONS}

\section{EXECUTIVE SUMMARY}

Sensitivity analyses were performed for fall-back positions (i.e., management actions) to accommodate potential off-normal and programmatic change events overlaid on the waste volume projections and their uncertainties. These sensitivity analyses allowed determining and ranking tank system high-risk parameters and fal7-back positions that will accommodate the respective impacts. This quantification of tank system impacts shows periods where tank capacity is sensitive to certain variables that must be careful7y managed and/or evaluated. Identifying these sensitive variables and quantifying their impact will allow decision makers to prepare fal7back positions and focus available resources on the highest impact parameters where technical data are needed to reduce waste projection uncertainties.

For noncomplexed waste, the period of capacity vulnerability occurs during the years of single-shell tank (SST) retrieval (after approximately 2009) due to the sensitivity to several variables. Ranked by importance these variables include the pretreatment rate and 200-East SST so7ids transfer volume.

For complexed waste, the period of capacity vulnerability occurs during the period after approximately 2005 due to the sensitivity to several variables. Ranked by importance these variables include the pretreatment rate. 200-East SST solids transfer volume. complexed waste reduction factor using evaporation, and 200-West saltwel1 liquid porosity. 
For aging waste using current planning assumptions there were essentially no periods of capacity vulnerability until the final few years of SST retrieval (after approximate7y 2016). These later capacity needs are attributed to the increasing uncertainty associated with off-normal events such as the on-line date of the highcapacity vitrification facility and the initial double-shell tank leak occurrence rate.

The selection of particular fall-back positions to alleviate vulnerable tank capacity periods requires further analyses with the following emphasis:

1) the technical bases for these sensitive variables must be established and accepted so the resultant uncertainties are validated and 2) the sensitive variables must be evaluated with various fall-back position groupings to determine alternative selections.

Based on these results, no actions were identified that require a change to the fiscal year (FY) 1996 Multi-Year Program Plan (WHC 1995). Further refinements and analyses are planned to enhance the model in analyzing upset scenarios and fall-back positions.

Programmatic and technical data needs are to validate variable ranges and associated programmatic risk for the general variable categories that affect available tank capacity space or affect timing and volumes of input waste sources. 
Finally, a sensitivity analysis approach to tank waste volume versus capacity was successfully demonstrated with a full complement of variables representing potential off-normal events and programmatic changes. These variables are operational in a flexible modeling platform accommodating variable range distributions that can be probabilistically sampled automatically. Thus, this modeling platform represents a strategic planning tool using a risk-based approach that quantifies tank waste system uncertainties and will aid in future decisionmaking. 


\section{CONTENTS}

ACRONYMS AND ABBREVIATIONS .......................... . . . . . . . . . . . . .

SUMMARY . . . . . . . . . . . . . . . . . . . . . . $x$

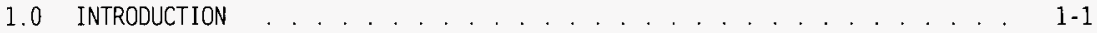

1.1 WHY IS A RISK-BASED APPROACH NEEDED FOR TANK FARM WASTE MANAGEMENT? 1-1

1.2 WHAT IS THE BACKGROUND OF THE ARES WORK? . . . . . . . . . . . . . . 1-1

1.3 WHAT IS THE SENSITIVITY ANALYSIS TECHNICAL STRATEGY? . . . . . . . . . 1-2

1.3.1 Defining A List Of Important Independent Variables With Ranges

1.3.2 Setting up Run Sets to Cover the variable Space

1.3.3 Making the Runs With the Model to Give Pass-Fail Answers 1-3

1.3.4 Ranking the Importance of the Independent Variables . . . 1-3

2.0 ANALYSIS PROCESS DESCRIPTION . . . . . . . . . . . . . . . . . . . . . . . 2-1

2.1 HOW WAS THE SIMULATION MODEL DESIGNED? . . . . . . . . . . . . . . . 2-1

2.2 HOW WERE THE OFF-NORMAL EVENTS MODELED? . . . . . . . . . . . . 2-1

2.3 HOW WERE THE FALL-BACK ACTIONS MODELED? . . . . . . . . . . . 2-3

2.4 HOW WAS THE STATISTICAL TREATMENT APPLIED? . . . . . . . . . . . 2-3

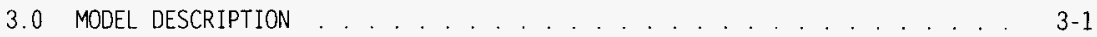

3.1 WHAT ARE THE MAJOR FEATURES OF THE SIMULATION MODEL? . . . . . . . . 3-1

3.2 WHAT ARE THE SIMULATION MODEL INTERFACES? . . . . . . . . . . . 3-2

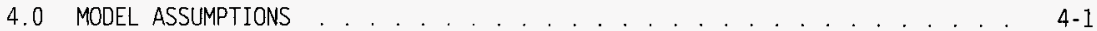

4.1 WHAT ARE THE TANK SYSTEM ASSUMPTIONS USED IN THE SIMAN MODEL? . . . 4-1

4.2 PHASE I MODEL CONVERSION . . . . . . . . . . . . . . . . . 4-1

4.2.1 Aging Waste Model Assumptions . . . . . . . . . . . . . . 4-1

4.2.2 Complexed Waste Model Assumptions . . . . . . . . . . . . 4-3

4.2.3 Noncomplexed Waste Model Assumptions . . . . . . . . . . 4-3

4.2.4 Other Model Assumptions . . . . . . . . . . . . . . . 4-3

4.3 PHASE II MODEL ANALYSIS . . . . . . . . . . . . . . . . . . . . 4-3

4.3.1 What Were the Tank System Off-Normal Events Considered? 4-5

4.3.2 What Were the Tank System Programmatic Changes Considered? 4-5

4.3.3 What Were the Tank System Fall-Back Positions Considered? 4-13

4.3.4 How Were the Variable Ranges and Probability Distributions Assigned? . . . . . . . . . . . . . . . 4-13

5.0 MODEL VALIDATION AND VERIFICATION . . . . . . . . . . . . . . 5-1

6.0 SENSITIVITY ANALYSIS RESULTS . . . . . . . . . . . . . . . . . . 6-1

6.1 WITHOUT FALL-BACK POSITIONS . . . . . . . . . . . . . . . . . . . 6-1

6.2 WITH FALL-BACK POSITIONS . . . . . . . . . . . . . . . . . . . 6-1

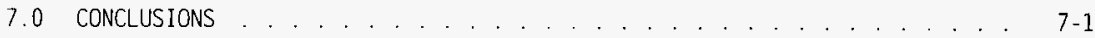




\section{CONTENTS (Continued)}

8.0 RECOMMENDATIONS . . . . . . . . . . . . . . . . . . . . 8 . .

9.0 NOTES ADDED IN REVIEW $\ldots \ldots \ldots \ldots$

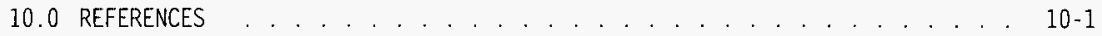

APPENDICES

APPENDIX A OFF-NORMAL EVENTS ................ . . . . .

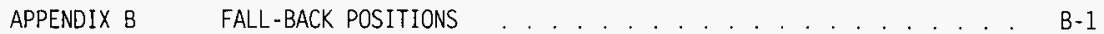

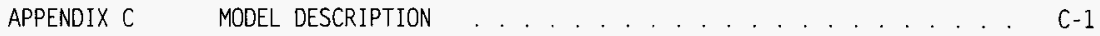

APPENDIX D TREATMENT OF RANDOM FAILURES . . . . . . . . . . . . . . . D D 1

APPENDIX E TEST RESULTS ...................... . . . . . . .

APPENDIX F GENERAL DESCRIPTION OF LATIN HYPERCUBE SAMPLER (LHS) $\ldots \ldots \ldots$ F-1

APPENDIX G GENERAL DESCRIPTION OF SIMAN ............... . . . . . .

APPENDIX H GENERAL DESCRIPTION OF RANKING SYSTEM . . ........ $\mathrm{H}-1$

\section{FIGURES}

2-1. Model Architecture ................ 2-2

2-2. Entropy-Based Population Splitting ........... 2- . .

5-1. Aging Waste Volume Projection .............. . . 5-2

5-2. Complexed Waste Volume Projection ... . . . . . . . . . . . 5-3

5-3. Noncomplexed Waste volume Projection ....... . . . . . . . 5-4

6-1. Variable Importance Tree Showing Variable Split Values for Noncomplexed Waste Without Fal1-Back Positions . . . . . . . . . . . . . . . . 6-4

6-2. Variance Importance Tree Showing Variable Split Values for Complexed Waste Without Fall-Back Positions ............... . . . 6-5

6-3. Variable Importance Tree Showing Variable Split Values for Aging Waste Without Fall-Back Positions . . . . . . . . . . . . . 6-6

6-4. Variable Importance Tree for Noncomplexed Waste Fall-Back Positions . . 6-8

6-5. Variable Importance Tree for Complexed Waste Fall-Back Positions . . . . . 6-9

6-6. Variable Importance Tree for Aging Waste Fall-Back Positions . . . . . . 6-10

6-7. Correlation Coefficients Versus Variable Ranking. . . . . . . . . 6-16

7-1. Success of Aging Tank Waste Containment with No Fali-Back Acation (NFB) , 7-2

7-2. Success of Aging Tank Waste Containment with Fa11-Back Action (FB) . . . 7-2

7-3. Success of Complex Tank Waste Containment with No Fall-Back Action (NFB) 7-3

7-4. Success of Complex Tank Waste Containment with Fall-Back Action (FB) . . 7-3

7-5. Success of Noncomplex Tank Waste Containment with No Fal1-Back Action (NFB) . . . . . . . . . . . . . . . 7-4

7-6. Success of Noncomplex Tank Waste Containment with Fall-Back Action (FB) , 7-4

9-1. Success of Noncomplex Tank Waste Containment with Fall-Back Action (FB) 9-3

9-2. Success of Noncomplex Waste Containment with No Fall-Back Action (NFB) . 9-3

9-3. Success of Complex Tank Waste Containment with Fall-Back Action (FB) . 9 9-4

9-4. Success of Complex Tank Waste Containment with No Fall-Back Action (NFB) 9-4

9-5. Success of Aging Tank Waste Containment with Fall-Back Action (FB) . . 9 9-5

9-6. Success of Aging Tank Waste Containment with No Fall-Back Action (NFB) . 9-5 


\section{CONTENTS (Continued)}

C-1. Summary Tank Waste Remediation System Conceptual Architectures . . . . . C-4

E-1. Volume of Complexed Waste Versus Capacity. . . . . . . . . . . . . . . . E-4

F-1. Intervals Used with a LHS of Size $n=5$ in Terms of the Density Function and Cumulative Distribution Function for a Normal Randon Variable . . . . F-7

F-2. Intervals Used with a LHS of Since $n=5$ in Terms of the Density Function and Cumulative Distribution Function for a Uniform Random Variable . . . F-8

F-3. A Two-Dimensional Representation of One Possible LHS of Size 5 Using

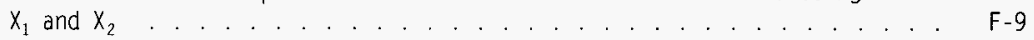

F-4. Interval Endpoints Used with a LHS of Size 5 (top) and Specific Values of $X$ Selected Through the Inverse of the Distribution Function (bottom) . F-11

TABLES

2-1. Correlation Ranked Variables for Complexed Waste Storage . . . . . . . . 2-5

2-2. Correlation Ranked Variables for Noncomplexed Waste Storage . . . . . . . 2-5

2-3. Correlation Ranked Variables for Aging Waste Storage . . . . . . . . . . 2-6

2-4. Entropy Ranked Variables for Complexed Waste Storage . . . . . . . . . . 2-7

2-5. Entropy Ranked Variables for Noncomplexed Waste Storage . . . . . . . . . 2-7

2-6. Entropy Ranked Variables for Aging Waste Storage . . . . . . . . . . . . 2-8

4-1. Phase I Assumptions as Postulated by ARES (GPSS Model) . . . . . . . . . 4-2

4-2. Phase I Off-Normal Conditions as Postulated by ARES (GPSS Mode1) . . . . 4-4

4-3. Off-Normal Conditions and Programmatic Changes . . . . . . . . . . . . 4-6

4-4. Phase II Off Normal Conditions at 10 Percent Correlation as Postulated By Risk Analysis Tool . . . . . . . . . . . . . . . . . . . . . . 4-8

6-1. Variables Ranked According to their Correlation with Maximum Exceedence volume $(R>10 \%)$

6-2. Variables Ranked According to their Correlation with Maximum Exceedence Volume $(R>5 \%)$

6-3. Fal1-Back Positions Ranked According to Their Effectiveness in Producing Successes . . . . . . . . . . . . . . . . . . . . . . . . . . . . . . . . 6-7

6-4. Variables Ranked According to their Correlation with Maximum Exceedence volume $(R>10 \%)$

6-5. Variables Ranked According to their Correlation with Maximum Exceedence volume $(R>5 \%)$. . . . . . . . . . . . . . . . . 6-13

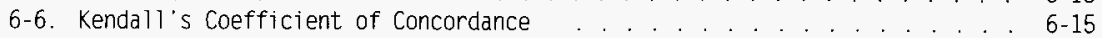

9-1. Adjusted Variable Distribution Ranges and Model Values . . . . . . . . . . 9-1

C-1. Variable Definitions Used In the SIMAN Model . . . . . . . . . . . . . . . . C-9

C-2. Input Data from OWVP. Rev.21. Table 10 (in kilogalions) . . . . . . . . . . . C-13

F-1. One Possible Selection of Values for a LHS of Size 5 from a Normal Distribution on the Interval $(0.10)$. . . . . . . . . . . . . F-12

F-2. Parameter Setup for Generating Two Random Samples of Size 20 Each . . . . F-14

$\mathrm{H}$-1. Top Level Flow Chart for Program Maxwe11 . . . . . . . . . . . . . . . . . . H-4 
WHC-SD-WM-ER-548 Rev. 0

\section{ACRONYMS AND ABBREVIATIONS}

$\begin{array}{ll}\text { ARES } & \text { Independent Contractor } \\ \text { CY } & \text { Calendar year } \\ \text { DOE } & \text { U.S. Department of Energy } \\ \text { DST } & \text { Double-Shell Tank } \\ \text { FY } & \text { Fiscal year } \\ \text { GPSS } & \text { General Purpose Simulation System } \\ \text { HLW } & \text { High-Level Waste } \\ \text { HVAC } & \text { Heating. Ventilation. and Air Conditioning } \\ \text { IMUST } & \text { Inactive Miscellaneous Underground Storage Tank } \\ \text { LAW } & \text { Low-Activity Waste } \\ \text { LHS } & \text { Latin Hypercube Sample } \\ \text { LLW } & \text { Low-Level Waste } \\ \text { MUST } & \text { Miscellaneous Underground Storage Tank } \\ \text { MWTF } & \text { Multi-Function Waste Tank Facility } \\ \text { NC } & \text { Noncomplexed } \\ \text { NCAW } & \text { Neutralized Current Acid Waste } \\ \text { NCRW } & \text { Neutralized Cladding Removal Waste } \\ \text { NDE } & \text { Nondestructive Examination } \\ \text { NDT } & \text { Nondestructive Testing } \\ \text { NRC } & \text { Nuclear Regulatory Commission } \\ \text { OWVP } & \text { Operational Waste Volume Projections } \\ \text { PUREX } & \text { Plutonium and Uranium Extraction Plant } \\ \text { SIMAN } & \text { SIMulation ANalysis Language Used for Event Simulation } \\ \text { SNL } & \text { Sandia National Laboratory } \\ \text { SST } & \text { Single-Shell Tank } \\ \text { TCO } & \text { Terminal Cleanout } \\ \text { TPA } & \text { Tri-Party Agreement or Hanford Federal Facility and Consent Order } \\ \text { TRU } & \text { Transuranic } \\ \text { TWRS } & \text { Tank Waste Remediation System } \\ \text { USNRC } & \text { United States Nuclear Regulatory Commission } \\ \text { WHC } & \text { Westinghouse Hanford Company } \\ \text { WVP } & \text { Waste Volume Projections } \\ & \end{array}$


WHC-SD-WM-ER-548 Rev. 0

\section{SUMMARY}

The ARES Corporation Multi-Function Waste Tank Facility (MWTF) support work (Thurkow et al. 1995) demonstrated the capability of using simulation analysis techniques as a risk-based management approach to double-shell tank (DST) volume versus storage capacity. However. the ARES work only considered a few representative off-normal events and fall-back actions to demonstrate the models. capabilities. Westinghouse Hanford Company (WHC) expanded on the ARES demonstration analyses to conduct further sensitivity analyses of fall-back positions (i.e., management actions) to accommodate potential off-normal and programmatic change events overlaid on the waste volume projections and their uncertainties.

Initially. the ARES models were converted to run using SIMAN. an advanced event simulation program. An expanded set of off-normal events and fall-back actions were probabilistically represented using approximately 150 variables. Sensitivity analyses were performed that allowed determining and ranking tank system high-risk parameters and fall-back positions that will accommodate the respective impacts. This quantification of tank system impacts shows periods where tank capacity is sensitive to certain variables that must be carefully managed and/or evaluated. Identifying these sensitive variables and quantifying their impact will allow decision makers to prepare fall-back positions and focus available resources on the highest impact parameters where technical data are needed to reduce waste projection uncertainties.

In anticipation that analysis of off-normal occurrences could identify unacceptable consequences, Mi lestone T21-96-228 (FY 1996) was established. This milestone requires issuing a change request that identifies the scope, schedule, and cost of implementing high risk fall-back positions. Fall-back positions are actions that may be taken to mitigate or eliminate off-normal occurrences or their unacceptabie consequences. Based on these analysis results, no actions were identified that require a change to the FY 1996 Multi-Year Program Plan (WHC 1995). Further refinements and analyses are planned to enhance the model in analyzing upset scenarios and fall-back positions. 
WHC-SD-WM-ER-548 Rev. 0

This page intentionally left blank. 


\subsection{INTRODUCTION}

\subsection{WHY IS A RISK-BASED APPROACH NEEDED FOR TANK FARM WASTE MANAGEMENT?}

Currently. Tank Waste Remediation System (TWRS) Tank Farm waste management is performed using a model based on a deterministic projection of waste volume versus waste tank storage capacity over the period of interest. These waste volume projections are needed by the TWRS Program to predict double-shell tank (DST) space usage. support near-term operations management of tank farm waste storage and consolidation. and support interim transition planning (waste storage to waste staging and processing activities)(Leach and Stah1, 1993). A risk-based waste volume projection (WVP) system is needed. Attributes of the systern will be to:

- Allow timely completion of sensitivity and parametric studies

- Quantify tank waste system impacts and uncertainties

- Include a probabilistic approach for tank system events

- Show periods of tank capacity vulnerability

- Develop fall-back positions for capacity needs

- Evaluate 'what-if' scenarios, such as:

- What if we can no longer use a certain DST?

- What if the waste retrieval schedule is delayed?

- What if a waste evaporator campaign is canceled?

- Permit making timely and durable decisions based on quantitative analysis

\subsection{WHAT IS THE BACKGROUND OF THE ARES WORK?}

The ARES Corporation MWTF support work (Thurkow 1995) demonstrated the capability of using simulation analysis techniques as a risk-based management approach to DST volume versus storage capacity. The risk-based simulation model probabilistically represents uncertainties in available data, assesses event probabilities, and serves as a tool for management to quantify the likelihood and consequences of various potential off-normal occurrences and programmatic changes.

The ARES work complemented existing annual waste projection studies. It also provided a proof-of-concept of a viable risk-based approach for DST waste volume versus storage capacity. The working simulation model replicated the standard Operational Waste Volume Projections (OWVP). Fall-back positions were developed for projections with a high risk of exceeding capacity. The base case analyzed showed that two additional tanks need designation for complexed waste. Adding these tanks from the noncomplexed waste designation was not deemed critical to accommodating noncomplexed waste requirements. The ARES work considered a few off-normal events (e.g., DST loss, cesium return stream from pretreatment is doubled, three year pretreatment delay. etc.) and fall-back positions to demonstrate the models. capabilities. However, the impact of these events stil1 lacked technical bases, and the fall-back positions were identified and applied manually.

WHC expanded on the ARES demonstration analyses to conduct further analysis of fall-back positions (i.e.. management actions) to accommodate potential off-normal events overlaid on the WVPS and their uncertainties. 
WHC-SD-WM-ER-548 Rev. 0

\subsection{WHAT IS THE SENSITIVITY ANALYSIS TECHNICAL STRATEGY?}

The technical strategy for the sensitivity analysis follows general methods for uncertainty analysis advocated by Thomas and Cote (1983) to the U.S. Department of Energy (DOE) and by Iman and Helton (1987) to the U.S. Nuclear Regulatory Commission (NRC). The application of Latin Hypercube Sampling (LHS) and expert system tools in this analysis were based on similar toołs for failure studies of waste containers in geologic repositories (Russell et al..1988. Jansen and Lester 1988. and Zimmerman et a1. 1990).

To conduct a sensitivity analysis a complete list of important variables. including off-normal events and fall-back positions must be sampled, runs must be made using the physical model, and variables must be ranked from the results of the runs. Later the distributions of higher ranking variables would be documented in more detail and their effects would be examined with a more refined model (Russell et al. 1988).

There are four parts to the strategy for ranking the variables: (1) defining a list of important independent variables with ranges; (2) setting up run sets to cover the variable space: (3) making the runs with the ARES tank system model to give pass-fail answers to whether the waste volume exceeds the tank capacity; and (4) ranking the independent variables by statistical analysis using expert systems or hierarchical importance trees (Jansen and Lester 1988 and Zimmerman et a1. 1990).

\subsubsection{Defining A List of Important Independent Variables With Ranges}

To get a perspective on the risk associated with tank volume projections, a group of interested experts met and decided on a list of potentially important independent variables and the variable parameter ranges that are likely to affect waste volumes or tank capacities. Variable ranges were selected as the widest that might reasonably be expected.

At most a few dozen variables were intended to be selected by opinions of the knowledgeable experts. However, the final total was approximately 150 variables. Twenty-seven of the variables came from those already present in the ARES risk-based tank system model (Thurkow et a1. 1995). Seventy-six variables came from the characteristics of the off-normal events, changes in strategies, and policy decisions that might occur for the 28 DST and 149 single-shell tank (SST) systems. while another 44 variables came from mitigating actions or fall-back positions.

\subsubsection{Setting up Run Sets to Cover the Variable Space}

The total number of runs to be made was decided in advance to be 200 . To sparsely cover the entire variable range space by the Latin Hypercube Sampler (LHS), the total number of runs should be approximately five times the number of variables (Russell et a1. 1988). Upon discerning that there would be approximately 
150 variables, the number of run sets was increased to 1,000. After the total number of runs and the distributions of the variables had been input into the LHS program (Iman 1984), sets of tank system model inputs for each run were generated by the LHS.

No value of any input variable was repeated in the run sets (except for date roundoffs to the nearest year and positions of switches), and thus it is not possible to plot results holding any variable constant. Plots of these one-at-atime variations can be created when testing the tank system model response to single variables at the design point (Jansen and Lester 1988).

\subsubsection{Making the Runs With the Model to Give Pass-Fail Answers}

To achieve a proper statistical analysis it was necessary to run al1 of the LHS generated run sets with the tank system model. The pass-fail results were recorded for each run set. Even though the tank system model had a relatively short run time. distributions of parameters contained within the model required approximately 500 runs to give statistically valid pass-fail answers for each run set.

\subsubsection{Ranking the Importance of the Independent Variables}

The run sets and results were put into an expert system program (Zimmerman et al., 1990). A specific version of the expert system code (Appendix H) was subsequently written to expand the processing capability from 30 variables to over 150 variables. The new code was validated by comparison of new expert system results for sample run sets to those using the original commercial software.

The expert system ranks the variables' importance by determining which variables have the most influence on the results. The ranking method used was one in which the results population is systematically split at various points to achieve the most order of results (i.e., reduces disorder or entropy). This entropy-based method achieves optimum order when the split populations present the least possible number of ways to achieve the respective result set (Section 2.4). This process is repeated for each variable to identify the most influential variables in determining the results and also to provide the critical variable values at the optimum split points.

The successive entropy reduction process yields a hierarchical tree with branches leading down from the pass-fail test. The most important variable was at the top level, and the second most important variables were at the second level. The variable importance represents the amount of influence a specific variable has in determining the pass-fail results. Sometimes subtle tertiary effects resulted in a variable being repeated at lower levels than the level at which it first appeared (Thomas and Cote 1983), but the net result was a general ranking of the independent variables in importance. 
Separate variable trees were developed for each of three waste types: complexed, noncomplexed, and aging wastes, each of which must be confined in separate tanks. The three trees produced different rankings, but a single composite list of important variables was made rather than a cross ranking between different waste types.

The first ranking was done for model calculations with the switches for fall-back positions turned off. A second set of model calculations was done with each of the fall-back position switches randomly varied between on and off. After ranking the variables a composite list of important variables was made for future work (Section 8.0).

Fal1-back positions were evaluated based on their effectiveness in promoting success. Because each fall-back switch was off for half of the 1,000 runs, these runs were discarded and the number of successes in the remaining 500 runs was estimated. The fall-back position with the highest fraction of successes in the 500 runs for which it was turned on was ranked most effective. The result was a priority list of effectiveness of fall-back positions tried singly. Importance trees were also developed for effectiveness of sequential fall-backs, but cost/benefit evaluations will also be needed to develop strategies for sequential fal]-back application.

In subsequent refined analyses only the top-ranked variables on the pruned tree will be used (Thomas and cote 1983). The uniform or loguniform distributions of the top-ranked variables on the tree will be replaced by more representative data-based distributions, such as Weibull or normal distributions of variables (Iman 1984). 


\subsection{ANALYSIS PROCESS DESCRIPTION}

\subsection{HOW WAS THE SIMULATION MODEL DESIGNED?}

The SIMAN (Appendix G) Risk-Based Assessment Model simulates DST capacity versus volume generated from major and minor waste generators. The waste volumes are comprised of three waste types: aging. complexed, and noncomplexed. Uncertainty associated with delays, failures of equipment. and programmatic changes are evaluated to assess DST capacity during peak waste volume movements. Currently. the model simulates 26 incoming waste streams and 4 reduction streams (Figure 2-1). To quantify uncertainty and evaluate DST capacity during peak waste volume movement periods, three variable categories are introduced. To assess importance ranking and sensitivity analysis of variables the three categories are: 1) failure:

2) internal; and 3) fall-back position variables (Figure 2-1).

\subsection{HOW WERE THE OFF-NORMAL EVENTS MODELED?}

Failure variables range from DST tank leaks to possible fires in the tank farms. Typically. failure variables decrease waste volume in the system. decrease available capacity. or offset waste schedules. These failures represent categorical acts of nature, equipment failures, programmatic changes, or general work stoppage. For instance. DST leakage is represented by two variables. These two variables are the DST leak occurrence initial rate (/yr) and the DST leak occurrence rate slope (/yr/20yr). A DST leak occurrence initial rate (for importance ranking purposes only) ranges from one DST leak in 100 years to one DST leak in 33 years. Because DSTs are aging with time, the rate of occurrence of a leak increases from 7 percent to 14 percent (Variable 2 [Appendix A]). These two variables are combined into one model parameter to represent the failure frequency of DST tanks due to a leak in the primary containment shel1. These two variable distributions are varied by the LHS. The LHS reduces the number of run sets required to analyze model sensitivity due to the DST leakage variables while ensuring a representative view for entire variable ranges. There are 76 failure variables represented in current modeling efforts (Appendix A).

Internal variable distributions have uniform or loguniform distributions affecting volumes from waste generators. These distributions can increase or decrease the volume input by generators. One example is the pretreatment rate distribution that varies in the range of 50 percent to 150 percent of its nominal rate of 30 gallons/minute (Variable 89 [Appendix A]). Distribution ranges for pretreatment rate and other internal variables are uniformly varied in the LHS. There are 27 internal variables in current modeling efforts. 


\section{Existing Operations}
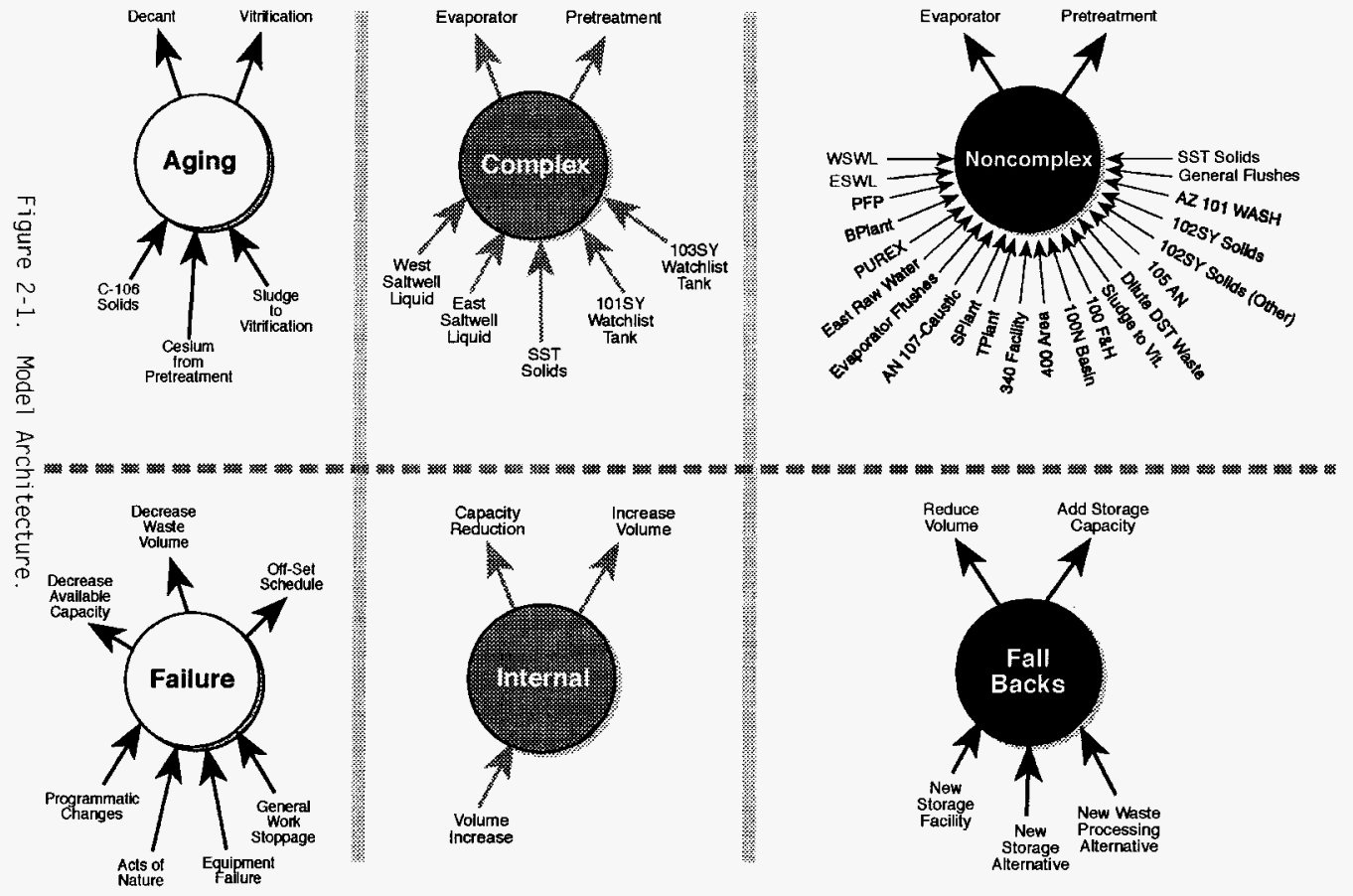
WHC-SD-WM-ER-548 Rev. 0

\subsection{HOW WERE THE FALL-BACK ACTIONS MODELED?}

Fal1-back position variables add storage capacity or reduce waste volume coming to the DST storage system. These variables range from using SSTs for temporary storage capacity to adding chemical agents that reduce incoming volume. Forty-four variables are represented in the current model.

All of these variables are assigned distributions, switched on and off by LHS. and stochastically varied in the SIMAN model for 500 replications. These statistically independent replications are ranked in an "Expert System" where the importance of failure, internal, and fall-back position variables are compared and ranked against each other. The "Expert System" not only determines the best path toward failures and successes for the SIMAN model but helps to exclude variables that do not significantly impact results.

Although some fall-back positions are purely hypothetical, the type of corrective action and/or result of a corrective action cannot be overlooked. Technical basis or lack of technical basis for fall-back positions are noted in Appendix B. Expert knowledge will be required to establish validated ranges for all variables.

\subsection{HOW WAS THE STATISTICAL TREATMENT APPLIED?}

The statistical treatment was performed by introducing random variables representing the uncertain and stochastic events described in Appendices $A$ through C. A brief explanation of the function (or purpose) of the random quantities can help put the treatment in context. While there is no distinction in the actual generation of random values, the purpose for introducing the random value has implications on the interpretation of the results.

For example, random variables can be introduced to perform sensitivity analysis, uncertainty analysis, or to represent the stochastic nature of a process with a known random behavior. Representative of stochastic processes, a prescribed random behavior for tank leak occurrence and failure of operational facilities is simulated with random variables. These variables were generated internal to the simulation with straight Monte Carlo, as explained in Appendix D. The use of random variables for sensitivity analysis is most important to the present analysis because the primary objective of this report is to determine and rank the important input variables.

Therefore, random quantities are primarily introduced to survey the variable values in the context of a sensitivity analysis. These values are generated external to the simulation. The coverage of variable ranges (consistent with the distributions) for a limited number of observations is effectively performed using the Limited LHS program from Sandia National Laboratory (SNL) (Appendix F). A sample size of 1,000 observations was used to survey ranges for the approximate 150 variables. 
As explained in Section 3.2. Model Interfaces, each of the 1.000 LHS observations yield a simulation averaged over random failures and leaks. Using the full set of observations allows calculation of a mean and standard deviation in waste volume and in available storage capacity in each year

Each variable set observation is analyzed with respect to the maximum exceedence volume $\left(V_{e x}\right)_{r}$ obtained, defined as the greatest value of waste volume minus storage capacity over time. Notice that this definition allows a comparison of projections with vulnerable tank capacity periods occurring at different times. Thus, time information is lost that would relate a high ranked variable to specific time periods. unless that particular variable is itself constrained to specific time periods. All variables were ranked based on their correlation with the exceedence volume. The question is whether or not the variations in the results are correlated with variations in the independent variables. Correlations were computed with ranked data that maps all variables $v_{j}$ to integers $R_{j}$ in $\left[1, N_{o b s}\right]$; therefore. al 1 the means become:

$$
\langle R\rangle \equiv \frac{\left(N_{o b s}+1\right)}{2}
$$

and the standard deviations become:

$$
\sigma \equiv \sqrt{\frac{\left(N_{o b s}^{2}-1\right)}{12}}
$$

where $\mathbb{N}_{O b S}$ is 1.000. Spearman's rank correlation (Korn and Korn 1961) is given by:

$$
r_{j}=\frac{\left\langle\left(R_{j}-\langle R\rangle\right)\left(R_{\text {evol }}-\langle R\rangle\right)\right\rangle}{\sigma^{2}}
$$

The significance of $r_{j}$ is understood by making the assumption that the exceedence volume is independent of an input variable $v_{j}$. For $\mathrm{N}_{O B S}=1.000$ the chance of finding $r_{j}>0.0815$ would be less than one in one-hundred $(\alpha \leq 0.01$, where $\propto$ represents the level of significance; for small $\propto$. there is greater confidence that the independent variable is related to the results). Therefore, larger values of $r_{j}$ make the original assumption of independence less plausible. In summation, the exceedence volume is more likely to depend on variables with large $r_{j}$. 
Tables 2-1 through 2-3 show the ranked variables having correlations (corr) of 5 percent and greater for the three waste types, respectively. A positive correlation implies exceedence volume increases with an increase in the selected variable value and a negative correlation implies a decrease in exceedence volume.

Table 2-1. Correlation Ranked Variables for Complexed Waste Storage.

\begin{tabular}{|c|c|c|c|}
\hline Rank & Var No. & Corr & Variable Description \\
\hline 1 & 89 & -0.6738 & Pretreatment rate ( $x$ of nominal) \\
\hline 2 & 90 & 0.2646 & East SST solids $(\%)$ \\
\hline 3 & 29 & -0.2085 & Complexed waste volume reduction factor \\
\hline 4 & 90 & 0.1619 & West saltwell licuid (porosity, : ) \\
\hline 5 & 40 & 0.1507 & Volume of MUST waste to dilute (gal) \\
\hline 6 & 81 & 0.1211 & Percent complexed SST solids $(z)$ \\
\hline 7 & 39 & -0.1006 & Date dilution of MUST required $(C Y)$ \\
\hline 8 & 71 & 0.0938 & Date of segregation rule violation (CY) \\
\hline 9 & 4 & 0.0834 & $\begin{array}{l}\text { Seismic requirements change } * \text { volume reduction } 48 " \\
\text { impact }\end{array}$ \\
\hline 10 & 72 & -0.0697 & Schedule delay due to new path forward (yr) \\
\hline 11 & 38 & 0.0620 & Dilution factor of MUSTS \\
\hline 12 & 44 & -0.0607 & K-Basin waste volume increase factor \\
\hline 13 & 50 & 0.0606 & Date of discovery of old waste (CY) \\
\hline 14 & 58 & 0.0578 & Date of contractor changeover (CY) \\
\hline 15 & 3 & -0.0554 & Date of seismic requirements change (CY) \\
\hline 16 & 35 & -0.0554 & Date regulatory change affects volume (CY) \\
\hline 17 & 22 & 0.0532 & Volumes occupied by liquid waste accumulation (tanks) \\
\hline 18 & 1 & 0.0511 & Initial OST leak occurrence rate $(1 / y r)$ \\
\hline
\end{tabular}

Table 2-2. Correlation Ranked Variables for Noncomplexed Waste Storage.

\begin{tabular}{|c|c|c|l|}
\hline Rank & Var. No. & Corr & \multicolumn{1}{|c|}{ Variable Description } \\
\hline 1 & 89 & -0.8716 & Pretreatment rate (\% of nominal) \\
\hline 2 & 92 & 0.3160 & East SST solids (\%) \\
\hline 3 & 40 & 0.1240 & Volume of MUST waste to dilute (ga ) \\
\hline 4 & 71 & -0.0843 & Date of segregation rule violation (CY) \\
\hline 5 & 98 & 0.0770 & East flush water (kgal) \\
\hline 6 & 72 & -0.0701 & Schedule delay due to new path forward (yr) \\
\hline 8 & 29 & 0.0612 & Complexed waste volume reduction factor \\
\hline 10 & 36 & 0.0598 & Di lution factor to become safe \\
\hline 11 & 38 & 0.0591 & Di lution factor of MusTs \\
\hline 13 & 95 & 0.0493 & B-Plant waste Volume (kgal) \\
\hline
\end{tabular}


Table 2-3. Correlation Ranked Variables for Aging Waste Storage.

\begin{tabular}{|c|c|c|l|}
\hline Rank & $\begin{array}{c}\text { Var. } \\
\text { No. }\end{array}$ & \multicolumn{1}{|c|}{ Corr } & \multicolumn{1}{|c|}{ Variable Description } \\
\hline 1 & 87 & 0.7357 & Volume of cesium to pretreatment (kga1) \\
\hline 2 & 23 & 0.5012 & $\begin{array}{l}\text { Date for the high-capacity vitrification facility to be } \\
\text { online (CY) }\end{array}$ \\
\hline 3 & 1 & 0.2366 & Initial DST leak occurrence rate (1/yr) \\
\hline 4 & 22 & 0.2037 & Volumes occupied by liquid waste accumulation (tanks) \\
\hline 5 & 4 & 0.1654 & Seismic recuirements change \% volume reduction 48" impact \\
\hline 6 & 2 & 0.1325 & DST leak occurrence rate slope (1/yr $\star 2)$ \\
\hline 7 & 72 & 0.0943 & Schedule delay due to new path forward (yr) \\
\hline
\end{tabular}

To confirm the described correlation-based variable rankings and to extract a critical value for each variable for which its greatest influence occurs, an information entropy-based method was used (Section 1.3.4 and Appendix H). Tables 2-4 through 2-6 show the ranked variables for the top 10 entropy reducing variables for the three waste types.

Table 2-4. Entropy Ranked Variables for Complexed Waste Storage.

\begin{tabular}{|c|c|c|c|l|}
\hline Rank & Var. No. & $\begin{array}{c}\text { Variable Split } \\
\text { Value }\end{array}$ & Entropy & \multicolumn{1}{|c|}{ Variable Description } \\
\hline 1 & 89 & $9.0717 \mathrm{E}+01$ & $8.53 \mathrm{E}-01$ & $\begin{array}{l}\text { Frequency of significant } \\
\text { ashfall. }\end{array}$ \\
\hline 2 & 71 & $1.9999 \mathrm{E}+03$ & $9.99 \mathrm{E}-01$ & $\begin{array}{l}\text { Date of segregation rule } \\
\text { violation. }\end{array}$ \\
\hline 3 & 29 & $3.9524 \mathrm{E}-01$ & $1.00 \mathrm{E}+00$ & $\begin{array}{l}\text { Complexed waste volume } \\
\text { reduction factor. }\end{array}$ \\
\hline 4 & 90 & $5.4630 \mathrm{E}+01$ & $1.00 \mathrm{E}+00$ & $\begin{array}{l}\text { West saltwell 1iquid } \\
\text { (porosity. kgal). }\end{array}$ \\
\hline 5 & 92 & $1.0533 \mathrm{E}+02$ & $1.00 \mathrm{E}+00$ & $\begin{array}{l}\text { East single-shell tank solids } \\
\text { (kgal). }\end{array}$ \\
\hline 6 & 40 & $6.4088 \mathrm{E}+05$ & $1.00 \mathrm{E}+00$ & $\begin{array}{l}\text { Volume of Must waste to } \\
\text { dilute (gal). }\end{array}$ \\
\hline 7 & 62 & $2.0002 \mathrm{E}+03$ & $1.01 \mathrm{E}+00$ & $\begin{array}{l}\text { Date of replacement of } \\
\text { government customer. }\end{array}$ \\
\hline 8 & 52 & $1.9901 \mathrm{E}+00$ & $1.01 \mathrm{E}+00$ & $\begin{array}{l}\text { Increased rate of saltwell } \\
\text { pumping factor. }\end{array}$ \\
\hline 10 & 39 & $2.0065 \mathrm{E}+03$ & $1.01 \mathrm{E}+00$ & $\begin{array}{l}\text { Date dilution of MusTs } \\
\text { required (CY). }\end{array}$ \\
\hline
\end{tabular}


Table 2-5. Entropy Ranked Variables for Noncomplexed Waste Storage.

\begin{tabular}{|c|c|c|c|l|}
\hline Rank & Var. No. & Var. Split Value & Entropy & \multicolumn{1}{|c|}{ Variable Description } \\
\hline 1 & 89 & $1.0805 \mathrm{E}+02$ & $3.45 \mathrm{E}-01$ & Pretreatment rate (kgal). \\
\hline 2 & 92 & $9.0238 \mathrm{E}+01$ & $4.21 \mathrm{E}-01$ & East single-shell tank solids (kgal). \\
\hline 3 & 55 & $2.0118 \mathrm{E}+03$ & $4.23 \mathrm{E}-01$ & $\begin{array}{l}\text { Date of delay of start of disposal } \\
\text { (CY). }\end{array}$ \\
\hline 4 & 71 & $2.0089 \mathrm{E}+03$ & $4.30 \mathrm{E}-01$ & $\begin{array}{l}\text { Date of segregation rule violation } \\
\text { (CY). }\end{array}$ \\
\hline 5 & 69 & $1.2330 \mathrm{E}-03$ & $4.31 \mathrm{E}-01$ & $\begin{array}{l}\text { Frequency of significant ashfall } \\
\text { (yr). }\end{array}$ \\
\hline 6 & 72 & $1.2602 \mathrm{E}+00$ & $4.33 \mathrm{E}-01$ & $\begin{array}{l}\text { Schedule delay due to new path } \\
\text { forward (yr). }\end{array}$ \\
\hline 7 & 78 & $1.9252 \mathrm{E}+03$ & $4.34 \mathrm{E}-01$ & Distribution for N-Basin waste (gal). \\
\hline 8 & 29 & $4.7703 \mathrm{E}-01$ & $4.35 \mathrm{E}-01$ & $\begin{array}{l}\text { Complexed waste volume reduction } \\
\text { factor. }\end{array}$ \\
\hline 9 & 98 & $1.3024 \mathrm{E}+02$ & $4.35 \mathrm{E}-01$ & East flush water (kgal). \\
\hline 10 & 40 & $6.2360 \mathrm{E}+05$ & $4.35 \mathrm{E}-01$ & Volume of MuST waste to dilute (gal). \\
\hline
\end{tabular}

Table 2-6. Entropy Ranked Variables for Aging Waste Storage.

\begin{tabular}{|c|c|c|c|c|}
\hline Rank & Var. No. & $\begin{array}{c}\text { Variable Split } \\
\text { Value }\end{array}$ & Entropy & Variable Description \\
\hline 1 & 87 & $8.9677 E+01$ & $4.65 E-01$ & $\begin{array}{l}\text { volume of cesium to } \\
\text { pretreatment }(\mathrm{kgal}) .\end{array}$ \\
\hline 2 & 23 & $2.0130 E+03$ & $6.33 E-01$ & $\begin{array}{l}\text { Date of outline of high } \\
\text { capacity vitrification } \\
\text { facility (CY). }\end{array}$ \\
\hline 3 & 22 & $2.4784 \mathrm{E}+00$ & $6.80 E-01$ & $\begin{array}{l}\text { Voluries occupied by liquid } \\
\text { waste accumulation (tanks). }\end{array}$ \\
\hline 4 & 4 & $4.0316 E+00$ & $6.81 E-01$ & $\begin{array}{l}\text { Seismic requirements change } \% \\
\text { volume reduction } 48^{\prime \prime} \text { impact. }\end{array}$ \\
\hline 5 & 27 & $2.0059 E+03$ & $6.87 E-01$ & $\begin{array}{l}\text { NCRW consolidation completion } \\
\text { without delay }(C Y) \text {. }\end{array}$ \\
\hline 6 & 48 & $1.9681 E+00$ & $6.87 E-01$ & $\begin{array}{l}\text { PUREX waste volume increase } \\
\text { factor. }\end{array}$ \\
\hline 7 & 95 & $2.7493 E+01$ & $6.87 E-01$ & B-Plant Waste Volume (kgal). \\
\hline 8 & 81 & $1.9960 \mathrm{E}-0]$ & $6.87 \mathrm{E}-01$ & Percent complexed SST solids. \\
\hline 9 & 59 & $1.9879 E+00$ & $6.87 E-01$ & $\begin{array}{l}\text { Schedule delay due to } \\
\text { contractor change }(\mathrm{yr}) \text {. }\end{array}$ \\
\hline 10 & 7 & $1.2194 \mathrm{E}-01$ & $6.87 E-01$ & $\begin{array}{l}\text { Failure rate of Evaporator } \\
\text { for Cy1998-2000 (1/yr). }\end{array}$ \\
\hline
\end{tabular}


The entropy-based method offers an intuitive procedure to separate populations of results into sets with the greatest distinction. It works as follows: First, three discrete results were defined using the exceedence volume $V$ ex and its standard deviation $\sigma_{\text {ex }}$ : (1) Failure at 90 percent confidence (F90), $V_{\text {ex }} \geq 1.644 \sigma_{\mathrm{ex}}$. (2) No Strong Conclusion (NC), $1.644 \sigma_{\mathrm{ex}} \leq V_{\mathrm{ex}} \geq-1.644 \sigma_{\mathrm{ex}}$, and (3) Success at 90 percent confidence $(S 90)$. $V_{\text {ex }} \leq-1.644 \sigma_{\text {ex }}$.

Second. the discrete results are ordered (or sorted) with respect to a selected variable. As shown in Figure 2-2, the result sets are split at distinguishable values of the independent variable where the multiplicity of ways that the two sets of results could have occurred is minimized (i.e.. reduces disorder or entropy). Eventually. a split point and multiplicity reduction is computed for each independent variable. The variables may then be ranked according to their multiplicity reduction. The large population limit of the logarithm of this multiplicity is the entropy. Therefore, the method has an intuitive statistical physics analog of an intelligent Maxwell's demon, selectively opening and closing the door on a critical value of gas molecule speed to separate a gas into two volumes that minimize the entropy of the system. The method itself suggests the possibility of continuing the process of entropy splitting on the resulting populations. This process has been used to most efficiently separate the original results set down to sets of pure results. The variable importance hierarchical tree structure resulting from the successive population splittings has been studied with respect to rule generating expert systems (Zimmerman et al. 1990).

Figure 2-2. Entropy-Based Population Splitting.

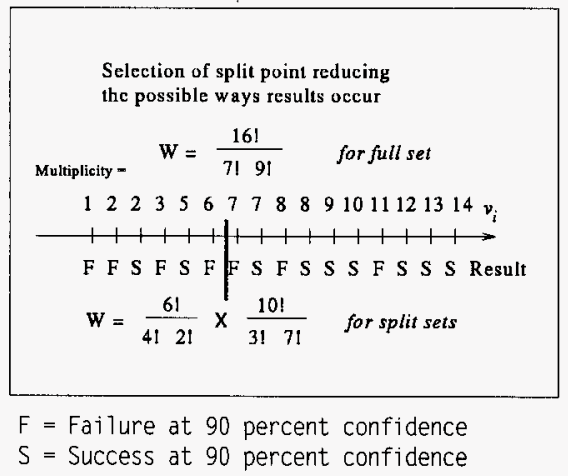

The expert system trees are shown (Section 6.0. Results) for each waste type to display the combined importance of the uncertain and off-normal event variables without the fall-back variables. 


\subsection{MODEL DESCRIPTION}

The three ARES General-Purpose Simulation System (GPSS) waste type models (aging, complexed, and noncomplexed) (Thurkow et a1. 1995) were successfully converted to SIMulation ANalysis (SIMAN) and further modified to allow sensitivity analyses of off-normal tank system events and fall-back actions to be conducted. The GPSS is a process oriented simulation language while SIMAN is an advanced process-oriented and/or event oriented simulation language.

The off-normal events were previously identified in an MWTF workshop, held in June 1995 (Awadalla 1995). Subsequent work identified the general causes of these events along with their respective dominant impacts on the tank waste system (e.g. . tank capacity. volume. or system schedule). These impacts were associated with their respective SIMAN model variables: value ranges were assigned to the variables: and sensitivity analyses were performed. Fall-back positions to accommodate potential off-normal events were also linked to model variables and included in the sensitivity analyses

The importance of off-normal events and fall-back positions was determined by examining tank volume versus capacity results from a simulation model that statistically surveys variable ranges representing the off-normal events and fallback positions. These analyses allowed determining and ranking tank system highrisk parameters and fall-back positions that will accommodate the respective impacts. This quantification of tank system impacts shows periods where tank capacity is sensitive to certain variables that must be carefully managed and/or evaluated. Identifying these sensitive variables and quantifying their impact will allow decision-makers to prepare fall-back positions and focus available resources on the highest impact parameters where technical data is needed to reduce waste projection uncertainties.

\subsection{WHAT ARE THE MAJOR FEATURES OF THE SIMULATION MODEL?}

The simulation model was designed to reproduce the global features of the OVWP (Strode and Koreski 1995). The schedule and volumes for waste generating sources to the DSTs are built into the simulation. The DST waste reduction effects of the evaporator operation, pretreatment, and vitrification are also simulated. The time step for simulated events is in one-quarter year intervals. although the resolution for the waste source schedule and operational facilities is a full year. Therefore. the random outage of operational facilities can occur on one-quarter year steps. Because individual DSTs are not explicitly represented. waste compatibility and segregation issues are treated by separately simulating the generation. processing. and storage of the three waste types: aging. complexed. and noncomplexed. The model was designed to allow variability in operational parameters for assessing the WVP uncertainty and to determine the consequences of possible upset conditions involving off-normal events. Additionally, the DST storage capacity assigned to a given waste type is treated as a variable to simulate variants on DST use assumptions and restrictions. The allowed variable types affecting the simulation are: (1) scale factors on known waste generating sources: (2) volume of additional unknown waste 
generating sources: (3) volume addition (or reduction) to present DST capacity; (4) failure frequency and outage time for operational facilities (such as an evaporator): and (5) occurrence date and duration shift in scheduted events.

\subsection{WHAT ARE THE SIMULATION MODEL INTERFACES?}

Model input information and output results are contained in text format files. The input file for a simulation run is a single set of values for the approximately 150 variables considered. This set of values (called an observation) is generated by the Limited L.HS program from SNL (Appendix F). Given the desired distributions and relationships for the 150 variables. LHS optimizes the coverage of variable space (consistent with the distributions) for a limited number of observations. A sample size of 1,000 observations was generated to survey variable ranges for the 150 variables. Therefore, 1,000 runs of the mode 1 were made to determine the waste volume/tank capacity dependence on the 150 variables. Additionally, each of the 1.000 observations required the simulation of 500 WVP histories to simulate failures of operational facilities and occurrence of tank leaks (see Appendix D). A utility program processes the model output after each observation to statistically summarize the 500 simulated histories with a mean and standard deviation on waste volume and tank capacity for each year for the three waste types. The files containing this summary information for 1.000 LHS observations serve as the interface to further statistical processing. 


\subsection{MODEL ASSUMPTIONS}

\subsection{WHAT ARE THE TANK SYSTEM ASSUMPTIONS USED IN THE SIMAN MODEL?}

The following discussion relates the tank system model assumptions. There are 28 DSTs available to store, receive, and transfer waste at the beginning of this simulation. For simulation purposes the tanks are aggregated into three control volumes representing three waste types: aging, complexed, and noncomplexed tanks. Historically, four of the DSTs were equipped to handle high-heat generation as aging waste tanks. These four tanks are 101-AZ, 102-AZ, 102-AY, and 101-AY. Currently. 102-AZ and 101-AZ are storing aging waste (Hanlon 1995). Tank 102-AY is designated as an aging waste spare tank and is used to store noncomplexed waste (Hanion 1995) Tank 101-AY is currently storing complexed waste (Thurkow et al. 1995). Five DSTs are designated to store complexed waste: 102-AN, 107-AN, 101-SY, 103-SY, and 101-AY (Hanion 1995). The 19 remaining DSTs store noncomplexed waste (Hanlon 1995).

Several underlying DST staging assumptions are incorporated for simulation purposes. These WVP assumptions are discussed in two sections, Phase I and Phase II. Phase I model assumptions were determined by ARES Corporation. Two additional assumptions are presented to further clarify model changes and modifications during conversion of the ARES models to SIMAN. Only base case simulation results and assumptions from ARES Corporation are included and verified. Off-normal analysis results by ARES Corporation are presented but not corroborated by the SIMAN model. Phase II model assumptions include Phase I assumptions but also survey impacts on the SIMAN Model due to MWTF off-normal conditions. Phase II assumptions for important variables are presented along with fall-back positions, as determined by uncertainty-based analysis tools (LHS. SIMAN Model. and Maxwel1 D).

\subsection{PHASE I MODEL CONVERSION}

Table 4-1 shows the Phase I assumptions as postulated by ARES. These assumptions are discussed for each tank waste type in the following sections. Possible off-normal conditions and fall-back positions postulated by ARES are shown in Table 4-2. The off-normal conditions represent three general areas of concern: (1) major hardware loss or programmatic change: (2) delay of key activities; and (3) major change to waste volume.

Section 9.0 discusses some assumption changes evaluated to address review comments associated with current planning assumptions that differ from the OWVP (Strode and Koreski 1995) used for this report.

\subsubsection{Aging Waste Model Assumptions}

Four aging waste tanks, at $980 \mathrm{kgal}$ capacity each, are available (Thurkow et al. 1995) for storage. This assumption is valid if future consolidation efforts are successful (Orme 1995 and Powel1 1995) (Table 4-1).

Collection of Tank C-106 and Tank 101-AZ solids into Tank 102-AZ (Neutralized Current Acid waste [NCAW] consolidation) successfully frees up another waste tank (Tank 101-AZ). Thus, Tank 102-AZ is fu11, and Tank 101-AZ and Tank 102-AY are free to receive waste. However, achieving a four tank aging waste capacity assumes that 
Table 4-1. Phase I Assumptions as Postulated by ARES (GPSS Model).

\begin{tabular}{|c|c|c|}
\hline Waste Type & Assumptions & Results \\
\hline Aging & $\begin{array}{l}\text { - } 1872 \text { kgal beginning waste } \\
\text { inventory. } \\
\text { - Tank-C-106 } 400 \mathrm{kgals} \text { waste added } \\
\text { in } 1997 \text {. } \\
\text { - Decant Tank AZ-102 in } 1997 \text { (In- } \\
\text { tank Washing Activity) } 647 \mathrm{kgal} \\
\text { removed from aging waste } \\
\text { inventory. } \\
\text { Additional high-heat waste added } \\
\text { in } 2005 \text {. (Source: Fretreatment } \\
\text { Cesium Stream) - this assumption } \\
\text { was later removed (see Section } \\
9.0) \text {. } \\
\text { - } \\
\text { volume reduction begins in } 2010 \\
\text { with the start of high-level } \\
\text { vitrification - this assumption } \\
\text { was later changed to reduction } \\
\text { beginning in } 2002 \text { based on the } \\
\text { current privatization initiative } \\
\text { (see Section } 9.0 \text { ). }\end{array}$ & $\begin{array}{l}\text { Uses portion of aging waste spare } \\
\text { Tank 2006- } 2010\end{array}$ \\
\hline Complexed & $\begin{array}{l}\text { - } 4.926 \text { kgal beginning waste } \\
\text { inventory. } \\
\text { - Saltwell pumping of complexed } \\
\text { waste in } 1995-2000 \text {. } \\
\text { - SST retrieval Adds volume } 2004 \text { - } \\
2015 \text { with minor peak in } 2009 \text {. } \\
\text { - Retrieval of Tank SY-101 and } \\
\text { Tank } 5 Y-103 \text { wastes represent no } \\
\text { volume increase. } \\
\text { Volume reduction occurs due to a } \\
\text { smal1 fraction of complexed } \\
\text { waste leaving through } \\
\text { evaporation and pretreatment } \\
\text { streams. (Pretreatment uses OST } \\
\text { accumulated waste). }\end{array}$ & $\begin{array}{l}\text { Complexed waste to exceed capacity } \\
\text { by } 1996 \text { unless two additional } \\
\text { noncomplexed waste tanks are } \\
\text { allocated. } \\
\text { Two tanks leaving noncomplexed } \\
\text { system does not have adverse affect } \\
\text { on system. } \\
\text { Removal of two noncomplexed tanks } \\
\text { for complexed use is reflected in } \\
\text { the capacity for noncomplexed } \\
\text { capacity curves for cases other than } \\
\text { base case. }\end{array}$ \\
\hline Noncomplexed & $\begin{array}{l}\text { - } 12424 \text { kgal Beginning waste } \\
\text { inventory. } \\
\text { - Saltwel1 Punping for } \\
\text { noncomplexed waste in } 1995-2000 \text {. } \\
\text { - SST and DST retrieval in } 2004- \\
2015 . \\
\text { - Large volume in projection for } \\
\text { SST retrieval and DST retrieval. } \\
\text { OST volume reductions occur due } \\
\text { to evaporation. pretreatment. } \\
\text { and vitrification processes. }\end{array}$ & $\begin{array}{l}\text { Noncomplexed waste will be available } \\
\text { for processing in the tanks by } 2015 \text {. } \\
\text { Three tanks can be reallocated from } \\
\text { the complexed and aging system to } \\
\text { account for the increasing } \\
\text { noncomplexed waste in } 2015 \text {. } \\
\text { Does not exceed capacity. }\end{array}$ \\
\hline
\end{tabular}


Tank 101-AY complexed wastes are processed. If Tank 101-AY waste transfer is delayed another DST is needed to store aging waste, requiring appropriate modifications (e.g., addition of cooling coils, ventilation system, etc.).

\subsubsection{Complexed Waste Mode1 Assumptions}

Five complexed waste tanks are available at the beginning of the simulation (Thurkow et a1. 1995). Also. two noncomplexed tanks are designated as complexed tanks for the period 1995-2015, per fall-back positions developed by ARES Corporation. while Tank 101-AY returns to the aging waste reservoir (Thurkow et a1. 1995).

\subsubsection{Noncomplexed Waste Model Assumptions}

Nineteen noncomplexed waste tanks are available at the beginning of the simulation (Thurkow et a1. 1995). Two noncomplexed tanks are designated to receive complexed waste per fall-back positions specified by ARES Corporation. After the year 2015. it is assumed that three complexed waste tanks will return to the noncomplexed tank capacity for waste retrieval and blending purposes.

\subsubsection{Other Model Assumptions}

Watchlist tanks are available to receive and transport waste (Thurkow et al. 1995).

\subsection{PHASE II MODEL ANALYSIS}

Phase Il model analysis simulated approximately 30 off-normal conditions that were identified as the most significant tank system events (Jensen 1995). These off-normal conditions reflect proposed risks to the DST system. Approximately 150 model variables were developed to represent these off-normal conditions. These 150 model variables represent three types of variables: failures, internal to system model, and fall-back positions. Failures. internal, and fall-back position variables are allowed to vary together. Seventy-six failure events. 27 internal and 44 fall-back position variables are superimposed (see Appendix A) in Phase II for analysis purposes.

Further significant assumptions are:

(1) Maximum delay to tank waste transfer activities due to a single event will be seven years (e.g. NCAW or NCRW consolidation fails to happen).

(2) Maximum delay for temporary tank or tank farm loss of service due to a single event will be three years (e.g., significant seismic event).

(3) New tank construction requires 10 years before tank becomes available to receive waste. 
(4) Evaporator processes tank waste in the following order: noncomplexed and then complexed.

(5) A minimum of 2 and a maximum of 20 new tanks can be constructed simultaneousiy.

(6) Waste generator volumes are extrapolated to year 2018 to allow for waste retrieval impacts to be analyzed. Also, fall-back positions and their system impacts can be effectively monitored.

Table 4-2. Phase I Off-Normal Conditions as Postulated by ARES (GPSS Model).

\begin{tabular}{|c|c|c|}
\hline Waste Type & Assumptions & Fa11-Back Pos. $\{$ Results\} \\
\hline Aging & $\begin{array}{l}\text { - 1. Loss of one UST } \\
\text { - 2. Two cesium (CS) or high-heat waste } \\
\text { streams from pretreatment. This } \\
\text { assumption was later removed (see } \\
\text { Section } 9.0 \text { ). } \\
\text { - 3. Safety requires dilution of one tank } \\
\text { by two times in } 1998 \text {. }\end{array}$ & $\begin{array}{l}\text { 1. Noncomplexed tank goes to aging } \\
\text { tank (mixer pump. cooling coils, } \\
\text { design and procurement [one to } \\
\text { three years]). } \\
\text { 2. Dilute (s stream by two, send } \\
\text { waste to noncomplexed tank (does } \\
\text { not affect aging or noncomplexed } \\
\text { capacity either). } \\
\text { 3. Convert noncomplexed tank to } \\
\text { aging tank by } 1998 \text {. Partial use } \\
\text { of spare tank in } 2008 \text { and } \\
\text { exceeding capacity in } 2007-2010 \text {. } \\
\text { (Mixer pump, cooling coils. } \\
\text { design and procurement one to } \\
\text { three years.) }\end{array}$ \\
\hline Complexed & $\begin{array}{l}\text { - 1. Loss of one DST. } \\
\text { - 2. Noncomplexed tank receives complexed } \\
\text { waste in } 1998 \text {. (200 kgal) } \\
\text { - 3. Pretreatment is delayed by } \\
\text { three years. Volume is exceeded after } \\
\text { year } 2007 .\end{array}$ & $\begin{array}{l}\text { 1. Allocate one additional } \\
\text { noncomplexed tank. } \\
\text { 2. None required. } \\
\text { 3. Retrieval of } \mathrm{Cs} \text { is delayed by } \\
\text { three years. }\end{array}$ \\
\hline Noncomplexed & $\begin{array}{l}\text { - 1. Loss of one DST. } \\
\text { - 2. Retrieval requires additional dilution } \\
\text { water doubling SST retrieval. } \\
\text { - 3. Terminal cleanout (TCO) of B-Facility, } \\
\text { PUREX. and } 100 \mathrm{~N} \text { facilities are } \\
\text { increased by a factor of } 10 \text {. }\end{array}$ & $\begin{array}{l}\text { 1. None required. } \\
\text { 2. Reduce SST solids. Retrieval to } \\
\text { match current volumes, continue } \\
\text { retrieving beyond } 2015 \text {. } \\
\text { 3. Postpone TCO of PUREX and } 100 \mathrm{~N} \\
\text { and } 242-\mathrm{A} \text { Evaporator use through } \\
2006 \text {. }\end{array}$ \\
\hline
\end{tabular}

1. Major hardware loss inflicted or programmatic change.

2. Delay of key activities.

3. Major change to waste volume.

Table 4.3 shows the off-normal conditions and programmatic changes identified for analysis. Table $C-1$ of Appendix $C$ discusses the approximately 150 variables derived to simulate the off-normal conditions along with fall-back positions. 
Tables 4-4 and 4-5 show the ranked or most important correlated variables above 10 percent and 5 percent correlation values (see discussion in Section 2.4) for postulated failures with and without potential fall-back positions included. The greater the correlation value between a variable and the results the greater the variable effect or importance on success or failure of waste tank capacity in containing the waste volume. As the correlation value decreases more variables are included that have a diminishing effect (or importance) on the success or failure of the system. Variable assumptions are discussed in detai1 in Appendices A and B.

\subsubsection{What Were the Tank System Off-Normal Events Considered?}

Off-normal events considered include DST leak, pipe breaks in contaminated areas of process facilities, unusual waste characteristics in SSTs, increased waste volume generation from the waste generators, discovery of buried hazardous waste near tank farms. industrial accident(s), seismic event, volcanic ash fall. significant flaws including corrosion or cracking found in DST(s), and fire in a tank farm facility. These events are discussed in detail in Appendix A.

\subsubsection{What Were the Tank System Programmatic Changes Considered?}

Changing seismic requirements, extended outage of the 242-A Evaporator. change to the waste volume reduction factor, and regulatory changes affecting waste volume are programmatic changes considered. A requirement to dilute certain tanks. accommodate Miscelianeous Underground Storage Tank (MUST) waste volume reduction dilution, accelerate saltwell pumping, and slipping of retrieval/disposal schedule were other programmatic changes considered. Contractor change. DOE replaced by a different agency, systems engineering issues. new tanks added to the watch list, and emerging scenarios from outside sources completed programmatic risk or changes considered by current simulation efforts.

These programmatic changes are not considered "off-normal" events as would be found during operations. but events that affect the generation and capacity by decisions at various levels. Typically, these would involve schedule delays for studies or potential turnovers. 
Table 4-3. Off-Normal Conditions and Programmatic Changes. (Sheet 1)

\begin{tabular}{|c|c|c|c|c|}
\hline off Hormal Conditions. & \multicolumn{4}{|c|}{ CAP VOL SGHED } \\
\hline DST Leak & $x$ & & & $\begin{array}{l}\text { Leaking DST waste type and vol.. evaporator queue } \\
\text { (1). leak height. (2), capacity adjustment. }\end{array}$ \\
\hline $\begin{array}{l}\text { Changing Seismic reqnt. (Tank Waste Height. } \\
\text { Sloshing) }\end{array}$ & $x$ & & & Overall tank waste height reduction factor (3) \\
\hline Privatization taking Storage Capacity & $x$ & & & Delay waste transfers, waste addition vol. (4) \\
\hline Don't Consolidate Similar Waste Types & $x$ & & & $\begin{array}{l}\text { *No mixing - included in retrieval transfer } \\
\text { schedule (5) }\end{array}$ \\
\hline S5T Leakage (until $1998+/-$ ) & & & $x$ & $\begin{array}{l}\text { SST leaking waste type and vol.. evaporator queue } \\
\text { (1) }\end{array}$ \\
\hline Extended outage of evaporator (years) & & & $x$ & Evaporator outage period (6) \\
\hline Waste Operations in 1998 (spare, staging...) & & & $x$ & $\begin{array}{l}\text { Evaporator availability, spare capacity reduced } \\
(7)\end{array}$ \\
\hline Cross-site (CS) transfer system & & & $x$ & $\begin{array}{l}\text { 01d CS system availability ( } 8 \text { ), new CS systen } \\
\text { availability, flush water addition vol. }\end{array}$ \\
\hline Waste Volume Reduction Factors & & $x$ & & Evaporator waste vol. scale factors. \\
\hline Pipe Breaks in contaminated areas (e.g. PLREX) & & $x$ & & Waste addition vol. \\
\hline Regulatory changes & & $x$ & & Waste addition vol, (9) \\
\hline Requirement to dilute safety tank(s) (101-5y) & & $x$ & & Waste addition vol. \\
\hline Accommodate "MUST" waste volume dilution (10:1) & & $x$ & & Waste addition vol. \\
\hline Characterization discovers unusual waste in SSTS & & $x$ & & $\begin{array}{l}\text { Tank or tank farm transfer delayed. waste addition } \\
\text { vol. (10) }\end{array}$ \\
\hline Increase waste generators output & & $x$ & & $\begin{array}{l}\text { * Included in generator waste vol. uncertainty } \\
\text { estimates }\end{array}$ \\
\hline $\begin{array}{l}\text { 0iscovery of "old" hazardous waste near tank } \\
\text { farms }\end{array}$ & & & $x$ & $\begin{array}{l}\text { Tank or tank farm transfer delayed, waste addition } \\
\text { vol. (11) }\end{array}$ \\
\hline Accelerate saltwell pumping & & & $x$ & Accelerate vol. addition schedule \\
\hline Failure of local transfers (pinch points) & & & $x$ & Delay waste transfers \\
\hline $\begin{array}{l}\text { Retrieval/Disposal scheduling (scenarios are } \\
\text { soft) }\end{array}$ & & & $x$ & Delay waste transfers, vitrification delay (12) \\
\hline TPA milestones not met or delayed & & & $x$ & Delay waste transfers. vitrification delay (13) \\
\hline Contractor change & & & $x$ & $\begin{array}{l}\text { Delay waste transfers, vitrification delay (time } \\
\text { period up to } 1 \mathrm{yr} .)\end{array}$ \\
\hline $\begin{array}{l}\text { Industrial Safety Issues Stopping Tank Farm } \\
\text { Activities }\end{array}$ & & & $x$ & $\begin{array}{l}\text { Delay waste transfers. vitrification delay (time } \\
\text { period up to } 1 \text { yr.) }\end{array}$ \\
\hline DOE Replaced by other agency & & & $x$ & $\begin{array}{l}\text { Delay waste transfers. vitrification delay (time } \\
\text { period up to } 1 \text { yr.) }\end{array}$ \\
\hline $\begin{array}{l}\text { Systems Engineering Impact (structure defined } \\
\text { inconsistent with path forward) }\end{array}$ & & & $x$ & * Other events cover these programatic impacts \\
\hline
\end{tabular}


Table 4-3. Off-Normal Conditions and Programmatic Changes. (Sheet 2)

\begin{tabular}{|c|c|c|c|}
\hline \multicolumn{2}{|l|}{ off Normal Condittons } & \multicolumn{2}{|c|}{ CAP YOL SCHED } \\
\hline New tanks to be added to the & & $x$ & $\begin{array}{l}\text { Temporary loss of tank capacity. Toss time period. } \\
\text { delay waste transfers }\end{array}$ \\
\hline $\begin{array}{l}\text { Emerging scenarios from outside sources } \\
\text { (national labs, review groups) }\end{array}$ & & $x$ & $\begin{array}{l}\text { Temporary loss of tank capacity. loss time per } \\
\text { delay waste transfers (14) }\end{array}$ \\
\hline "Significant" seismic event & & $x$ & $\begin{array}{l}\text { Temporary loss of tank capacity. loss time period, } \\
\text { delay waste transfers }\end{array}$ \\
\hline "Significant" ash fal? & & $x$ & $\begin{array}{l}\text { Temporary loss of tank capacity. loss time period. } \\
\text { delay waste transfers (15) }\end{array}$ \\
\hline $\begin{array}{l}\text { Violating segregation rules may change path } \\
\text { forward (reduced capacity. increased disposa } \\
\text { costs) }\end{array}$ & $X$ & & $\begin{array}{l}\text { Temporary loss of tank capacity. loss time period. } \\
\text { delay waste transfers, waste add. vol. (16) }\end{array}$ \\
\hline Potential primary NDE indications in DSTs & $X$ & & $\begin{array}{l}\text { Temporary loss of tank capacity. loss time period, } \\
\text { delay waste transfers }(17)\end{array}$ \\
\hline Fire in tank farm facilities & $x$ & & $\begin{array}{l}\text { Ternporary loss of tank capacity. loss time period. } \\
\text { delay waste transfers }\end{array}$ \\
\hline \multicolumn{4}{|c|}{ 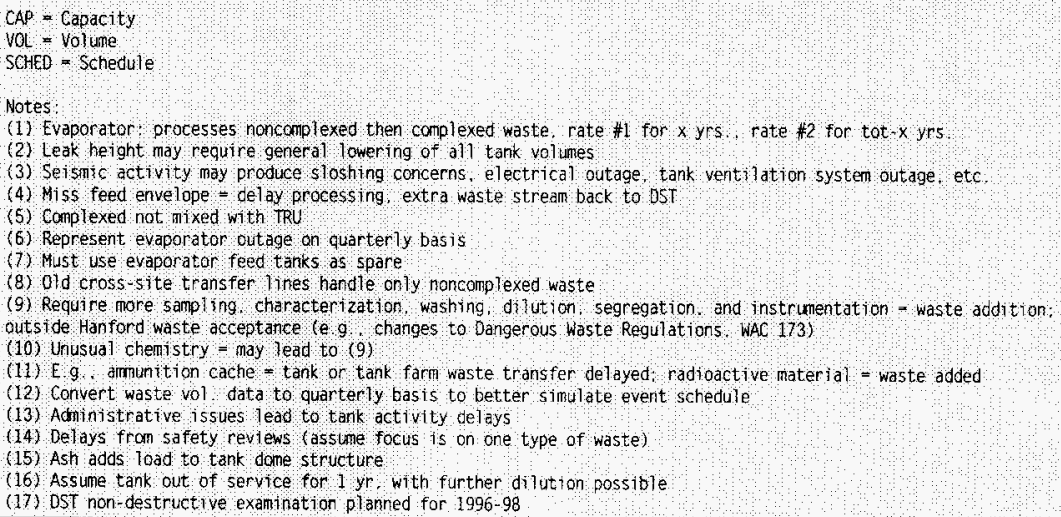 } \\
\hline
\end{tabular}


Table 4-4. Phase II off Normal Conditions at 10 Percent Correlation as Postulated By Risk Analysis Tool. (Sheet 1)

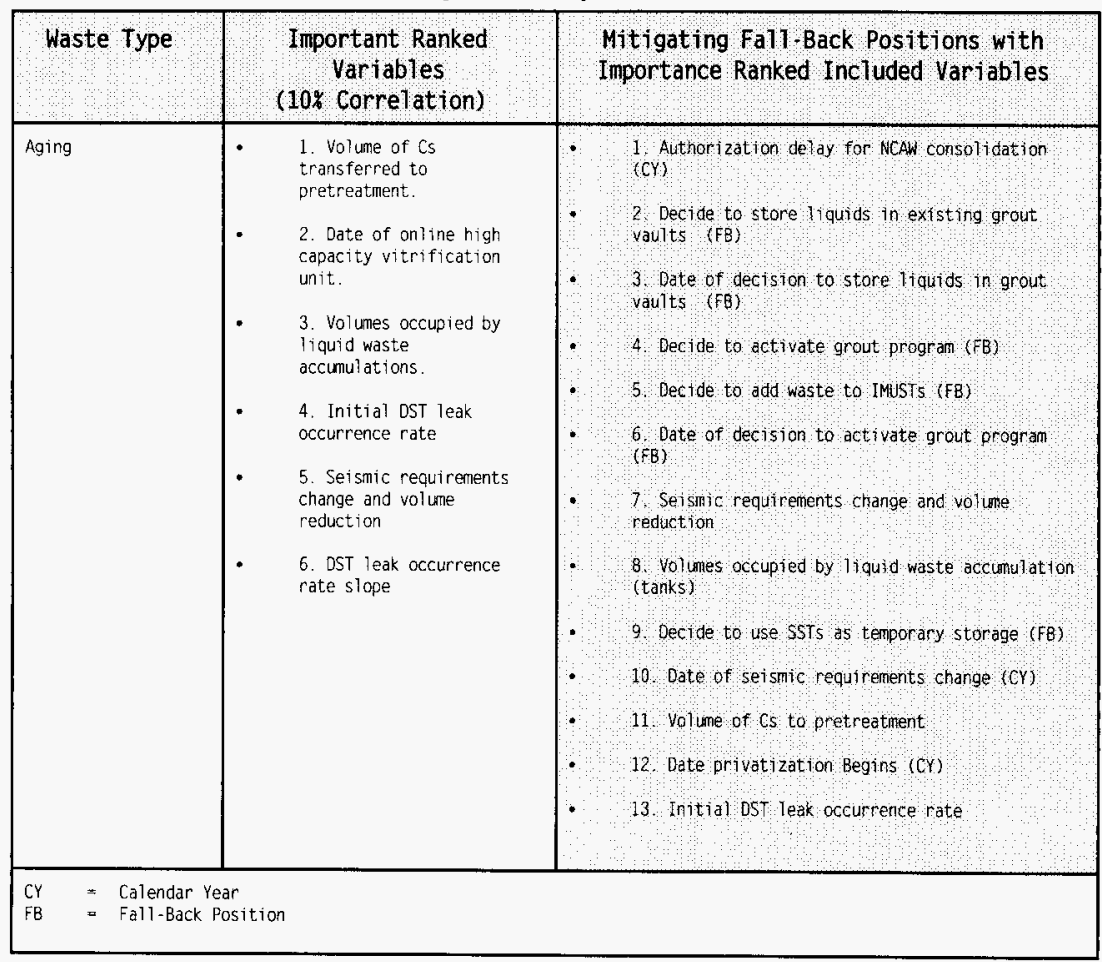


Table 4-4. Phase II off Normal Conditions at 10 Percent Correlation as Postulated By Risk Analysis To01. (Sheet 2)

\begin{tabular}{|c|c|c|}
\hline Waste Type & $\begin{array}{l}\text { Important Ranked } \\
\text { Variables } \\
\text { (10\% Correlation) }\end{array}$ & $\begin{array}{l}\text { Mitigating Fal1 Back Positions with } \\
\text { Importance Ranked Included Variables }\end{array}$ \\
\hline Complexed & $\begin{array}{l}\text { 1. Pretreatment rate } \\
\text { - } \\
\text { 2. East SST solids } \\
\text { 3. Comiplexed waste volume } \\
\text { reduction factor } \\
\text { 4. West saltwell liquid } \\
\text { (porosity. kgal) } \\
\text { 5. Volume of MUST waste to } \\
\text { dilute } \\
\text { 6. Percent complexed SST } \\
\text { solids. } \\
\text { 7. Date of dilutions of } \\
\text { MUST tanks required. }\end{array}$ & 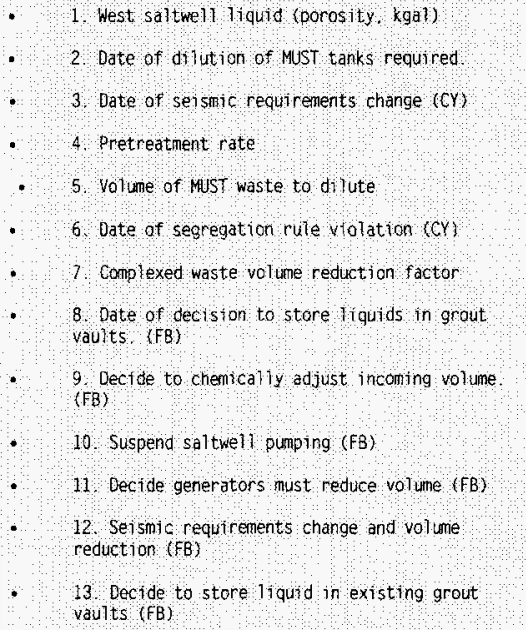 \\
\hline Noncomplexed & $\begin{array}{l}\text { 1. Pretreatment rate } \\
\text { (kgal) } \\
\text { 2. East SST solids } \\
\text { 3. Volume of MUST waste to } \\
\text { dilute. }\end{array}$ & 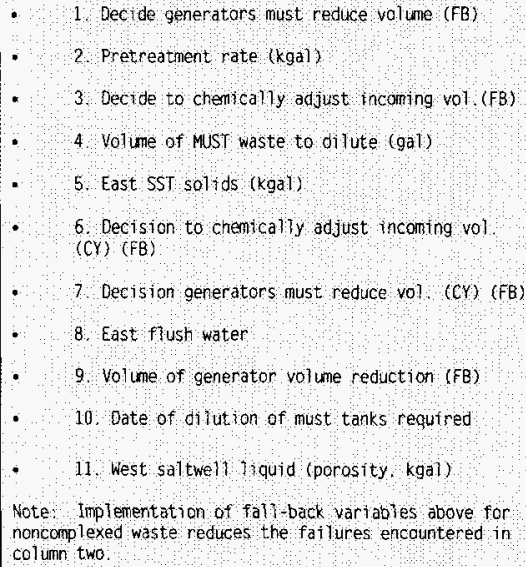 \\
\hline
\end{tabular}


Table 4-5. Phase II off Normal Conditions at 5 Percent Correlation as Postulated by Risk Analysis Too?. (Sheet 1)

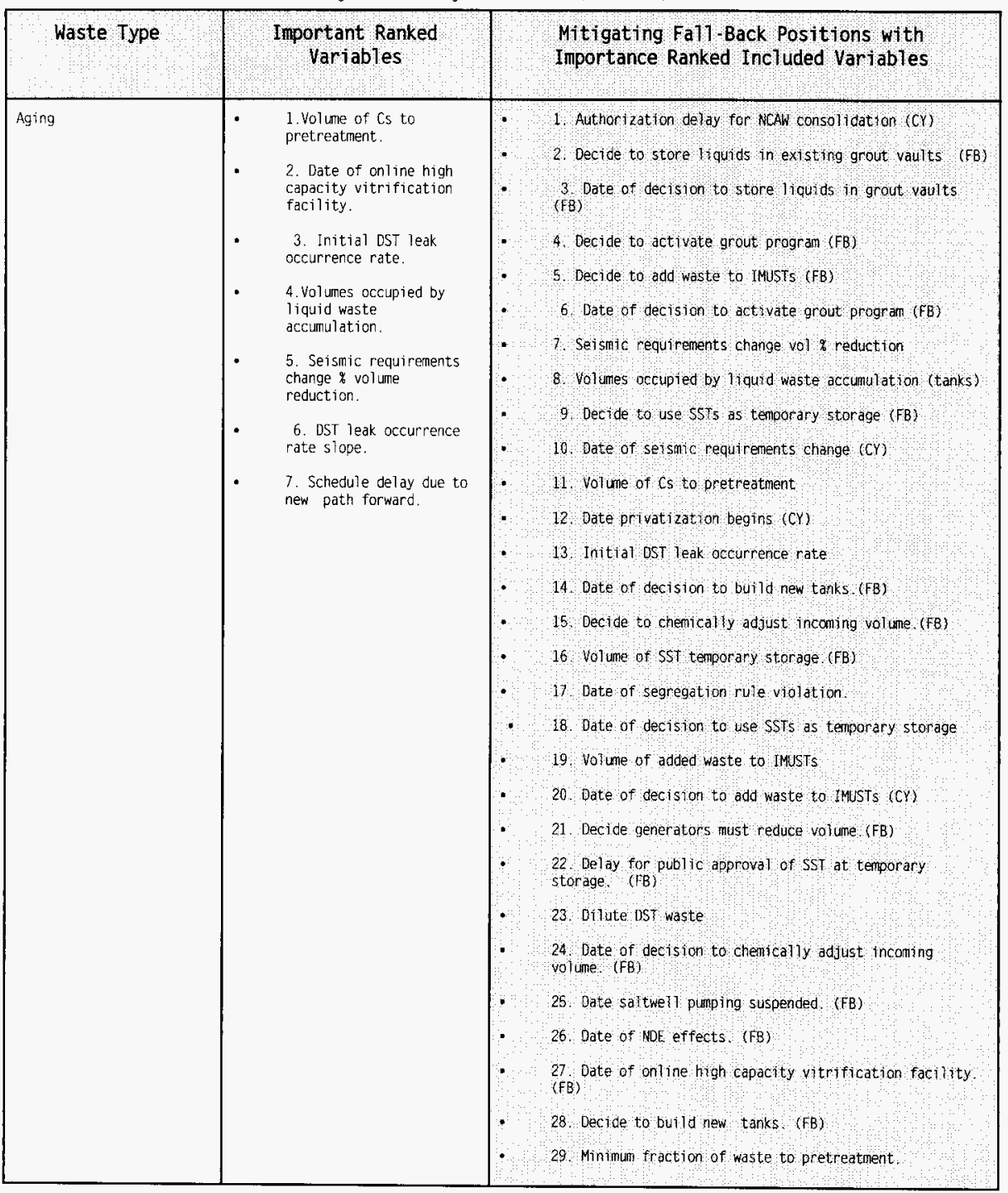


Table 4-5. Phase II Off Normal Conditions at 5 Percent Correlation as Postulated by Risk Analysis Tool. (Sheet 2)

\begin{tabular}{|c|c|c|}
\hline Complexed & 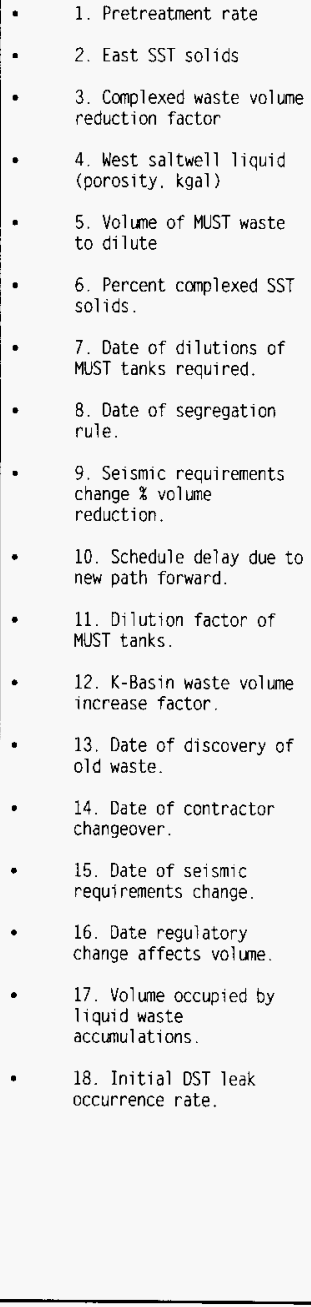 & 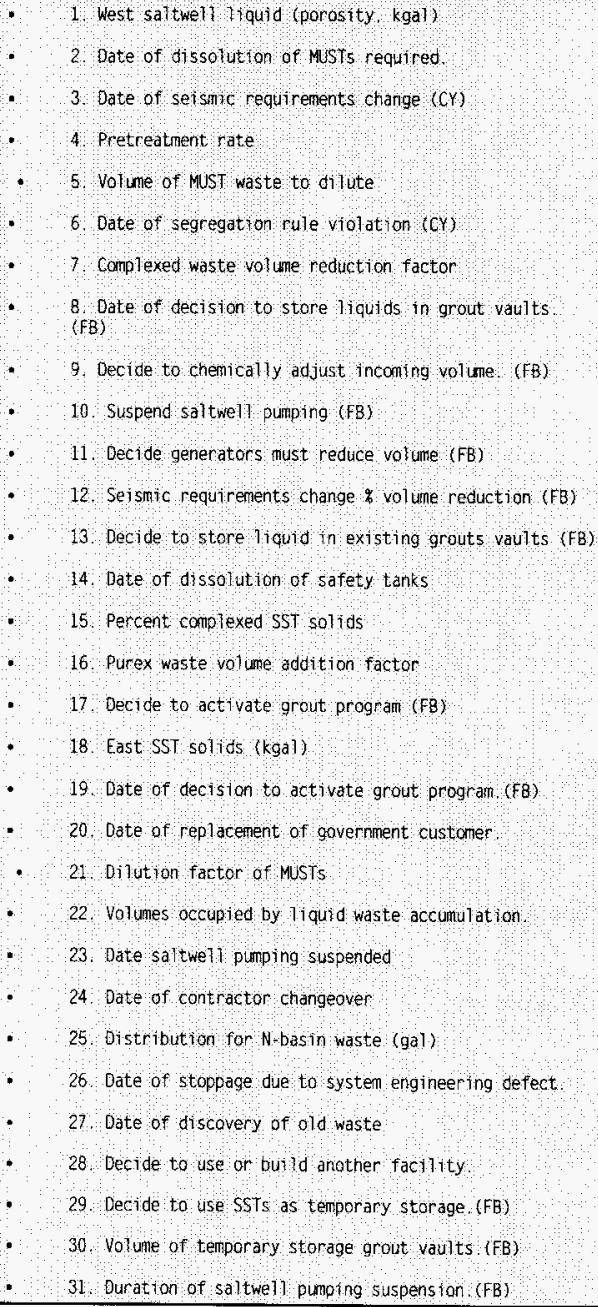 \\
\hline
\end{tabular}


Table 4-5. Phase II Off Normal Conditions at 5 Percent Correlation as Postulated by Risk Analysis Tool. (Sheet 3 )

\begin{tabular}{|c|c|c|}
\hline Waste Type & $\begin{array}{l}\text { Impartant Ranked } \\
\text { Variables }\end{array}$ & $\begin{array}{l}\text { Mitigating Fall-Back Positions with } \\
\text { Importance Ranked Included Variables }\end{array}$ \\
\hline Noncomplexed & $\begin{array}{l}\text { 1. Pretreatment rate } \\
\text { (kgal) } \\
\text { 2. East SST solids } \\
\text { 3. Volume of MUST waste } \\
\text { to dilute. } \\
\text { 4. Date of segregation } \\
\text { rule } \\
\text { 5. East flush water } \\
\text { (kgal) } \\
\text { 6. Schedule delay due to } \\
\text { new path forward (yr) } \\
\text { 7. Dilute oST waste } \\
\text { 8. Complexed waste volume } \\
\text { reduction factor } \\
\text { 9. Dilution factor to } \\
\text { become safe. } \\
\text { 10. Dilution factor of } \\
\text { MuSTs }\end{array}$ & 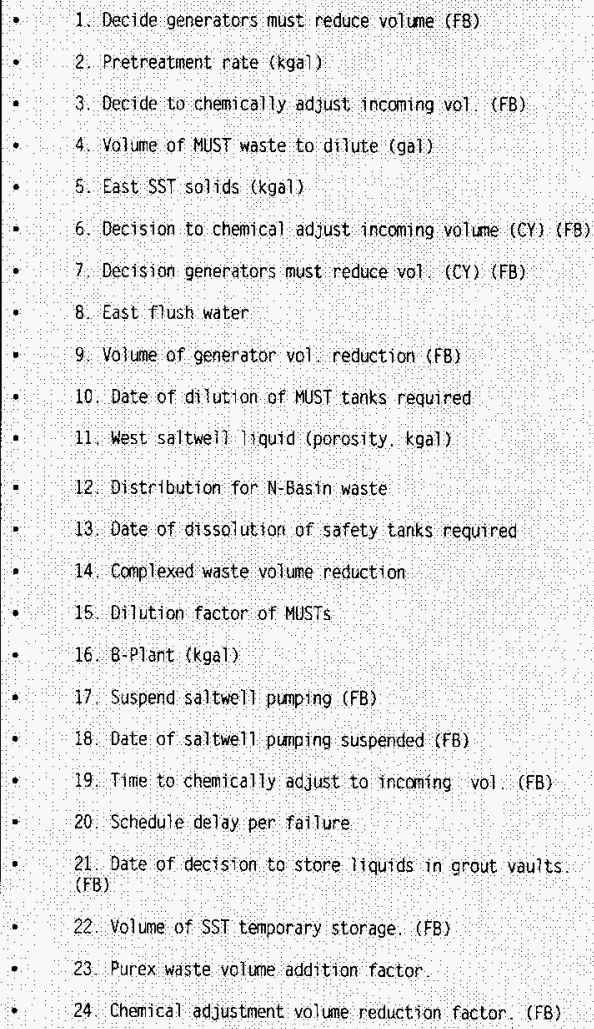 \\
\hline
\end{tabular}




\subsubsection{What Were the Tank System Fa11-Back Positions Considered?}

The fall-back positions considered in the analysis include delaying operations during vuinerable capacity periods, requiring the generators to process excess waste over the predicted quantities, suspending saltwell pumping. using SSTs as temporary waste storage. activating the grout program. using grout vaults for temporary waste storage, requiring waste generators to reduce volume of waste generated, building new tanks, adding waste to inactive miscellaneous underground storage tanks (IMUSTs) for temporary storage, and using chemical adjustment methods to reduce incoming volume. These fall-back positions were selected to help meet the tank waste capacity requirements to accommodate potential tank systems off-normal or programmatic changes. These fall-back positions still require technical evaluation before being implemented. The build new tanks option was selected as a fall-back position because the goal of the MWTF Phase-out program is to avoid or delay the need for new tanks.

\subsubsection{How Were the Variable Ranges and Probability Distributions Assigned?}

To get a perspective on the risk associated with tank volume projections, a group of interested experts first met and decided on a list of potentially important independent variables and their parameter ranges that are likely to affect waste volumes or tank capacities. Variable ranges were selected as the widest that might reasonably be expected.

The distribution of each parameter over the ranges was also needed. Uniform or loguniform distributions over the entire variable range were assumed. This procedure does not use the actual probability distributions or the design point in setting the ranges or distributions of variables. If data were available for the actual distributions, the data were used while setting the ranges. The nature and range of the variable determined whether uniform or loguniform distributions were used. While this procedure may overemphasize the effect of the range extremes, it is often used so that efforts will not be focused prematurely on the precision of distributions before the variables are ranked (Russel 1 et al.. 1988).

Future work will include evaluation of individual variable impacts along with the impacts of the assumed distributions of highest rank variables. Eventually. the uniform or loguniform distributions of the top-ranked variables on the tree will be replaced by more representative data-based distributions such as Weibul1 or normal distributions of variables (Iman 1984). 
WHC-SD-WM-ER-548 Rev. 0

This page intentionally left blank. 


\subsection{MODEL VALIDATION AND VERIFICATION}

Before to performing the sensitivity analysis, the ARES GPSS model was converted to SIMAN. McGraW-Hill Series in Industrial Engineering and Management Science provided analysis of language constructs in an article titled "Simulation Modeling and Analysis" by Averill M. Law and W. David Kelton. This analysis, along with internal expertise in the SIMAN language, provided the initial step for the Phase I Modeling of DST Risk Management items in SIMAN. This conversion phase included: (1) learning model constructs, (2) conversion of language, and (3) generation of output at the 90 percent confidence level. ARES Corporation provided model output for 30 runs, as well as technical consultation during this conversion process. Furthermore, ARES provided methodology for statistical analysis in determination of 90 percent confidence intervals for aging, complexed, and noncomplexed waste types.

The initial purpose of Phase I modeling work was to reproduce base case results from GPSS in SIMAN. This conversion resulted in two significant model process changes. First. when simulated evaporator failures occurred, volume scheduled to be removed by the evaporator was rescheduled for the next year. Second, in order for the sensitivity analysis to become stable, 500 replications were performed compared to the 30 replications by the GPSS model. Figures 5-1, 5-2, and 5-3 compare SIMAN model results to GPSS model results for the base case.

The discrepancy in these curves (Figures 5-2 and 5-3) reflect the need for more replications to determine the 90 percent confidence interval and waste accumulation due to evaporator failure. Statistical generation of these confidence intervals served as a validation of results. Peer review served to verify that model assumptions were consistently represented in Phase I and that additions and changes added value to results.

Phase II modeling work focused on incorporating approximately 30 "possible" risk events, which are summarized in Figure 2-1. These 30 risk events were categorically split into approximately 150 variables. A subset of these variables (i.e.. the first 18 variables) was used to demonstrate the ability to simulate and analyze results for sensitivity purposes and importance ranking and to validate and verify tool methodology. This tool consists of the LHS. SIMAN Risk-Based Model. post processors, and Expert Systems, respectively. Throughout development of the tool various checks were performed using the variable subset to verify results of the entire tool. These checks are reflected below:

1. Mean and standard deviation for each observation was determined.

2. Graphical representation of minimum and maximum values were produced. including uncertainty calculation associated with stochastic events using the SIMAN model.

3. LHS ranges were checked and changed as necessary based on interpretation of results 


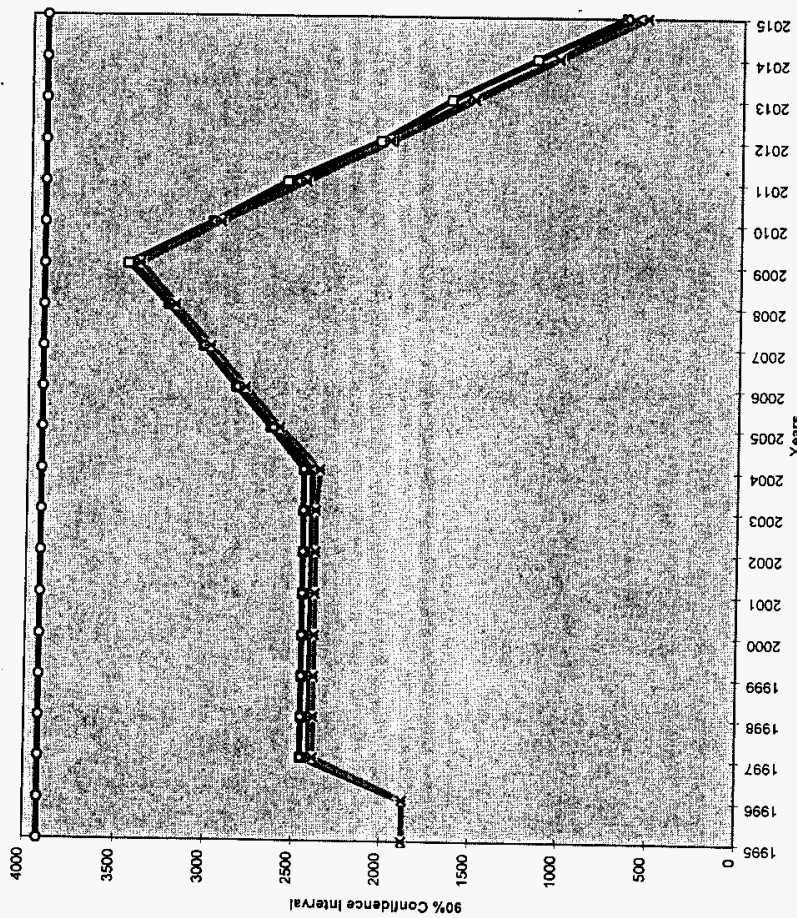

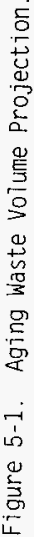


WHC-SD-WM-ER-548 Rev. 0
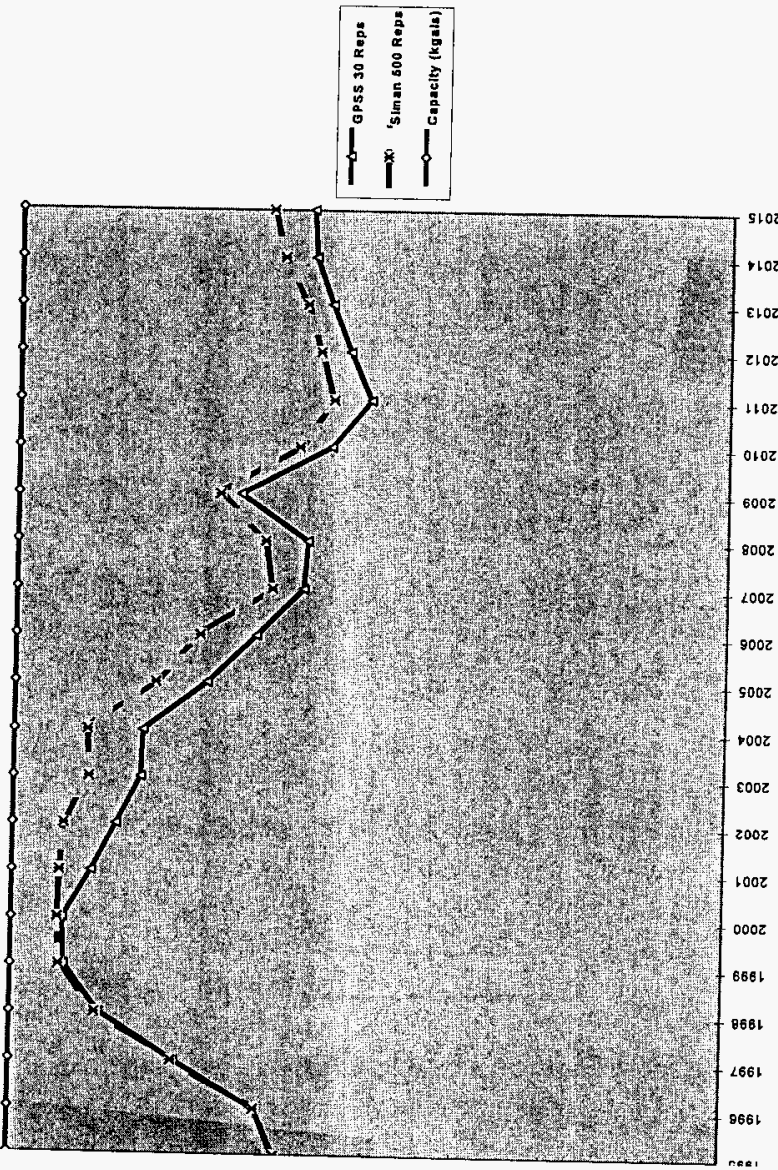


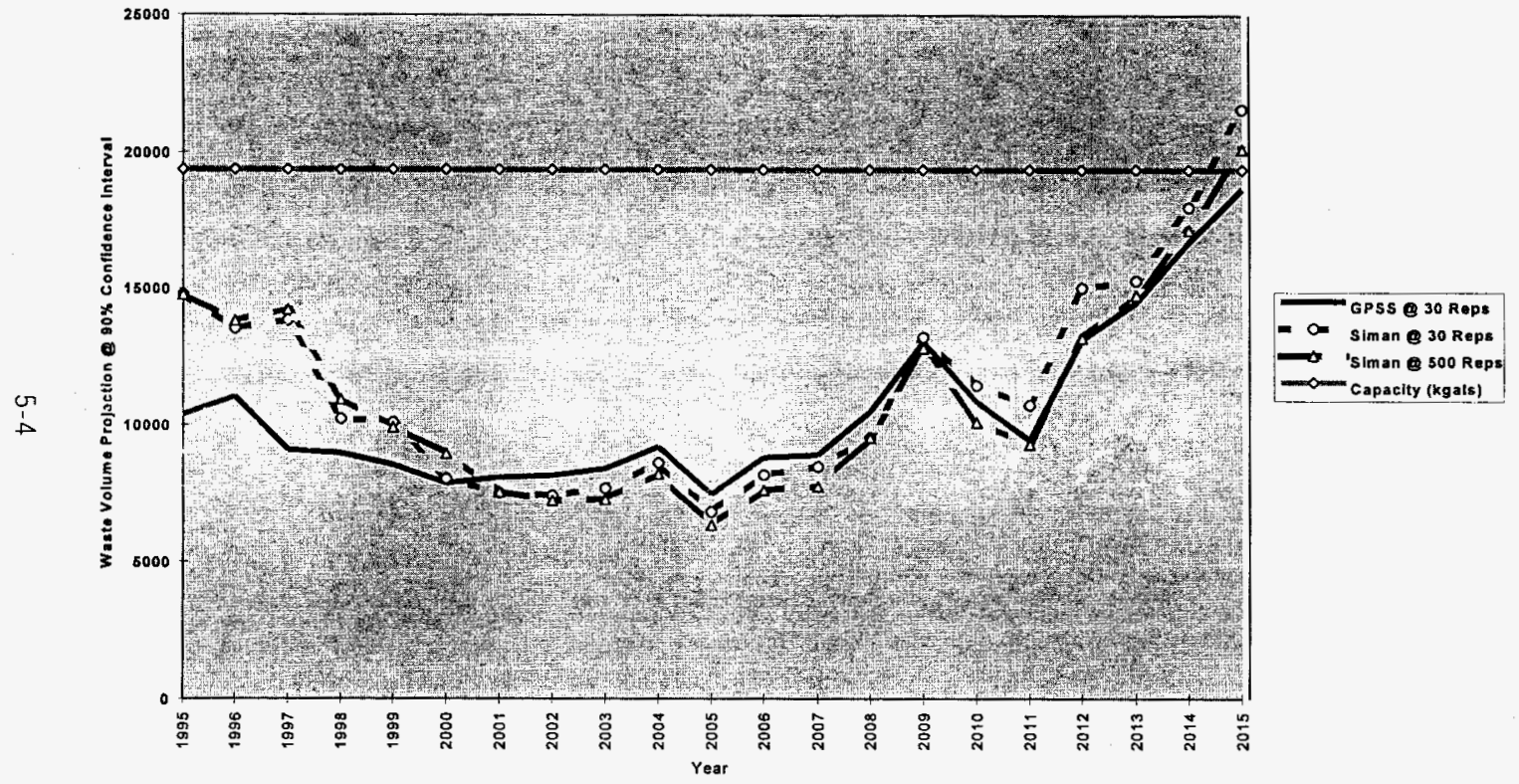

Figure 5-3. Noncomplexed Waste Volume Projection. 
4. Expert System output results were compared to graphs generated from maximum and minimum values. The Expert System uses raw ranges of LHS variables and the value of waste volume minus capacity to rank important variables.

5. A second "Expert System" (Maxwe11's D) was developed that corroborated 1st Fusion "Expert System" results. The second expert system al Iowed for an increased number of observations and parameters to be compared. 
WHC-SD-WM-ER-548 Rev. 0

This page intentionally left blank. 


\subsection{SENSITIVITY ANALYSIS RESULTS}

\subsection{WITHOUT FALL-BACK POSITIONS}

To determine the importance of internal model parameters and off-normal events a sensitivity analysis was conducted first without fall-back positions. Tables 6-1 and $6-2$, show the importance ranking of variables relative to success or failure of tank capacity to meet volume needs without fall-back positions for correlations at 10 percent and 5 percent. Figures $6-1,6-2$, and $6-3$ show the variable importance data hierarchically for each waste type with results of success and failure criteria, along with critical variable values at split points. The correlation with maximum exceedence volume means that the higher the correlation value the greater the variable effect on success or failure of waste tank capacity in containing the waste volume. As the correlation value decreases more variables are included that have a diminishing effect (or importance) on the success or failure of the system.

Tabie 6-1 shows 13 significant variables ranked above a 10 percent correlation cutoff (see Appendix A for variable descriptions). Of these thirteen, five are internal model variables and eight are off-normal events (refer to Figure 2-1). Each waste type has a different number of significant event contributions for exceeding tank capacity. For instance, noncomplexed waste exceedence volume is sensitive to the pretreatment rate, east SST solids volume, and the MUST dilution volume. A decrease in the pretreatment rate and an increase in east SST solids volume are significant enough to contribute to an inadequate capacity condition. Additional dilution of the MUST waste also contributes to inadequate capacity conditions at 10 percent correlation for noncomplexed waste

For complexed waste above 10 percent correlation the pretreatment rate, east SST solids volume, and complexed waste reduction factor are the top three significant variables. A decrease in the complexed waste volume reduction factor significantly affects the waste. The reduction factor ranges from 25 to 55 percent reduction of complexed waste. Overa11, seven important variables are ranked.

For aging waste the volume of cesium to pretreatment (see Section 9.0 discussion). the on-line date of the high-capacity vitrification facility, and the initial DST leak occurrence rate ranked as the top significant three variables. Six variables are ranked.

Summarizing, the table results show that the importance of off-normal variables depends on the specific needs and restrictions placed on each waste type. Reducing the cutoff to 5 percent correlation (see Table 6-2) increases the number of significant variables to 24 for the waste types, of which 7 are interna 1 and 17 offnormal. Results for fall-back variables are subsequently discussed to show possible pathways to success for periods of tank capacity vulnerability.

\subsection{WITH FALL-BACK POSITIONS}

The fall-back position variables were added and the sensitivity analysis was repeated. Table $6-3$ and Figures $6-4,6-5$, and $6-6$ show the ranking of the fal1-back positions in promoting success. The four fall-back positions that reduce the waste volume all rank above the four fall-back positions that increase the storage capacity. This results from the assumed large percentage decreases in generator 
volumes, while the tank capacity increases were relatively small. Further analysis of the significance of the fall-back positions is needed with accompanying cost estimates, estimates of variable distributions, and models of fall-back position combinations.

Table 6-1. Variables Ranked According to their Correlation with Maximum Exceedence Volume ( $R>10 \%$ ).

(fall-back variables not activated)

\begin{tabular}{|c|c|c|c|c|c|c|}
\hline Rank & Var & $\begin{array}{c}\text { Rank } \\
\text { NCmplx }\end{array}$ & $\begin{array}{c}\text { Rank } \\
\text { Cmplx }\end{array}$ & $\begin{array}{l}\text { Rank } \\
\text { Aging }\end{array}$ & Var Type & Variable Description \\
\hline 1 & 89 & 1 & 1 & - & I & Pretreatment rate (kgal) \\
\hline 2 & 92 & 2 & 2 & $-\ldots$ & I & East SST solids (kgal) \\
\hline 3 & 40 & 3 & 5 & $-\ldots$ & 0 & Volume of MUST waste to dilute (gai) \\
\hline 4 & 29 & $\ldots$ & 3 & $\ldots$ & 0 & Complexed waste volume reduction factor \\
\hline 5 & 90 & $\ldots$ & 4 & $\ldots$ & I & West saltwell liquid (porosity. kgal) \\
\hline 6 & 4 & $-\cdots$ & $\ldots$ & 5 & 0 & $\begin{array}{l}\text { Seismic requirements change * volume } \\
\text { reduction } 48 " \text { inpact }\end{array}$ \\
\hline 7 & 39 & $\cdots$ & 7 & $\ldots$ & 0 & Date dilution of MUST tanks required (CY) \\
\hline 8 & 1 & $\ldots$ & $\cdots$ & 3 & 0 & Initial DST leak occurrence rate (1/yr) \\
\hline 9 & 87 & $\ldots$ & $\cdots$ & 1 & I & Volume of cesium to pretreatment (kgar) \\
\hline 10 & 22 & -- & -- & 4 & 0 & $\begin{array}{l}\text { Volumes occupied by liquid waste } \\
\text { accumulation (tanks) }\end{array}$ \\
\hline 11 & 2 & -- & $\cdots$ & 6 & 0 & DST leak occurrence rate slope $(1 / y r * * 2)$ \\
\hline 12 & 23 & $\cdots$ & -- & 2 & 0 & $\begin{array}{l}\text { On-line date of high-capacity vitrification } \\
\text { facility (CY) }\end{array}$ \\
\hline 13 & 81 & --- & 6 & --- & I & Percent complexed SST solids \\
\hline
\end{tabular}

Notes:

$I$ = Internal Variable

$0=$ Off-Normal Variable

$F=$ Fall-Back Variable

Ncomplx = Noncomplex Waste

Cmplx = Complex Waste

$\operatorname{Var}=$ Variable

$\mathrm{CY}=\mathrm{Calendar}$ Year 
Table 6-2. Variables Ranked According to their Correlation with Maximum Exceedence Volume $(R>5 \%)$.

(fall-back variables not activated)

\begin{tabular}{|c|c|c|c|c|c|c|}
\hline Rank & Var & $\begin{array}{c}\text { Rank } \\
\text { NCmplx }\end{array}$ & $\begin{array}{c}\text { Rank } \\
\text { Cmplx }\end{array}$ & $\begin{array}{c}\text { Rank } \\
\text { Aging }\end{array}$ & $\begin{array}{l}\text { Var } \\
\text { Type }\end{array}$ & Variable Description \\
\hline 1 & 89 & 1 & 1 & $\cdots$ & $\mathrm{I}$ & Pretreatment rate (kgal) \\
\hline 2 & 92 & 2 & 2 & $\cdots$ & I & East SST solids (kgal) \\
\hline 3 & 40 & 3 & 5 & -- & 0 & Volume of MUST waste to dilute (gal) \\
\hline 4 & 71 & 4 & 8 & $\ldots$ & 0 & Date of segregation rule violation (CY) \\
\hline 5 & 98 & 5 & $\ldots$ & $-\ldots$ & I & East flush water (kgal) \\
\hline 6 & 72 & 6 & 10 & 7 & 0 & Schedule delay due to new path forward $(y r)$ \\
\hline 7 & 101 & 7 & $-\cdot$ & $--\cdot$ & I & Dilute DST waste (Kgal) \\
\hline 8 & 29 & 8 & 3 & $--\cdot$ & 0 & Complexed waste volume reduction factor \\
\hline 9 & 36 & 9 & - & $\ldots$ & 0 & Dilution factor to become safe \\
\hline 10 & 38 & 10 & 11 & $\ldots$ & 0 & Dilution factor of MUSI tanks \\
\hline 11 & 90 & $\cdots$ & 4 & $-\cdots$ & I & West saltwell liquid (porosity. kgal) \\
\hline 12 & 4 & -- & 9 & 5 & 0 & $\begin{array}{l}\text { Seismic requirements change * volume reduction } \\
48^{\prime \prime} \text { impact }\end{array}$ \\
\hline 13 & 50 & $\ldots$ & 13 & $\ldots$ & 0 & Date of discovery of old waste (CY) \\
\hline 14 & 44 & $\ldots$ & 12 & $\ldots$ & 0 & K-Basin waste volume increase factor \\
\hline 15 & 39 & +- & 7 & $\cdots$ & 0 & Date dilution of MUST required (CY) \\
\hline 16 & 58 & $\ldots$ & 14 & $\ldots$ & 0 & Date of contractor changeover (CY) \\
\hline 17 & 1 & $\ldots$ & 18 & 3 & 0 & Iritial DST leak occurrence rate (1/yr) \\
\hline 18 & 87 & $-\ldots$ & $\ldots$ & 1 & I & Volume of cesium to pretreatment (kgal) \\
\hline 19 & 35 & $-\cdots$ & 16 & -- & 0 & Date regulatory change affects volume (CY) \\
\hline 20 & 22 & -- & 17 & 4 & 0 & volumes occupied by liquid waste accumulation \\
\hline 21 & 3 & $\ldots$ & 15 & $\cdots$ & 0 & Date of seismic reguirements change (CY) \\
\hline 22 & 2 & $-\cdot$ & $\cdots$ & 6 & 0 & DST leak occurrence rate slope $\left(1 / y r^{* * 2)}\right.$ \\
\hline 23 & 23 & -- & $\cdots$ & 2 & 0 & $\begin{array}{l}\text { On-line date of high-capacity vitrification } \\
\text { facility (CY) }\end{array}$ \\
\hline 24 & 81 & $\ldots$ & 6 & $\ldots$ & I & Percent complexed SST solids \\
\hline
\end{tabular}

Notes:

$I$ = Internal Variable

$0=$ Off-Norma $]$ Variable

$F=F a l l-B a c k$ Variable

Ncmp 1x = Noncomplexed Waste

Cmplx = Complexed waste

Var = Variable

$C Y=$ Calendar Year 
Figure 6-1. Variable Importance Tree Showing Variable Split Values for Noncomplexed Waste Without Fal1-Back Positions.

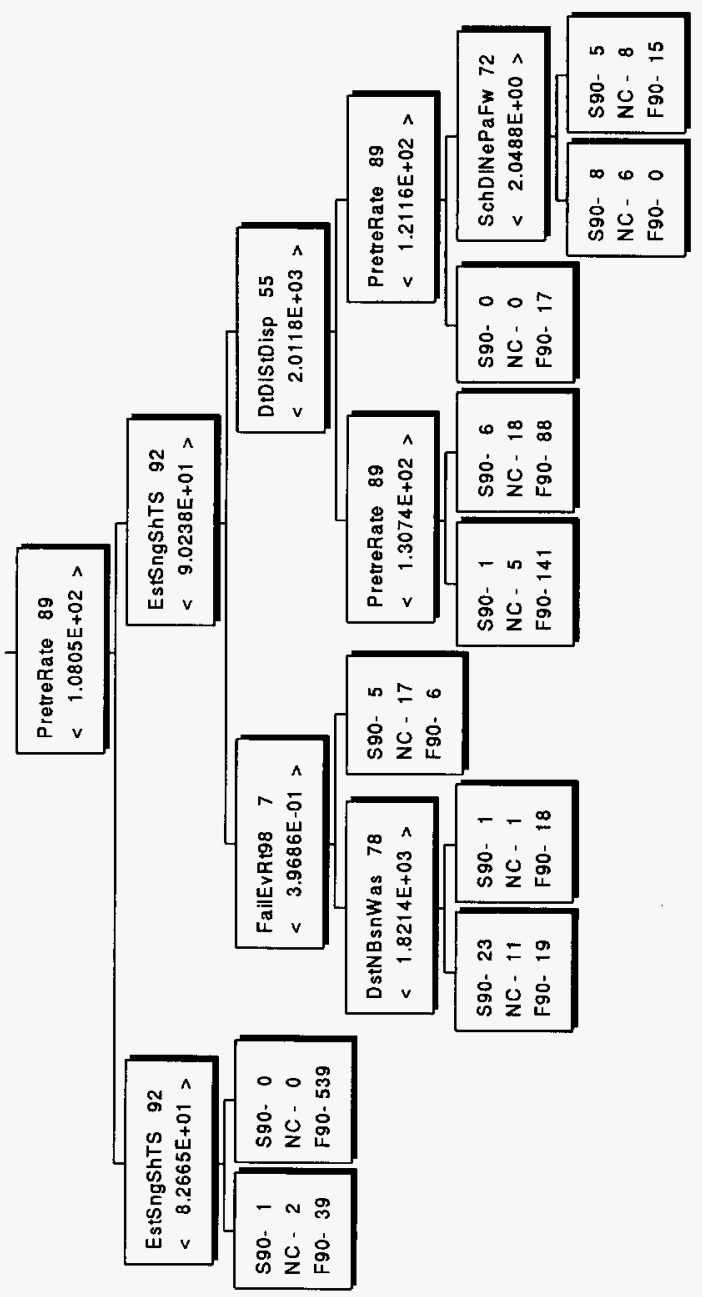


Figure 6-2. Variance Importance Tree Showing Variable Split Values for Complexed Waste Without Fall-Back Positions.

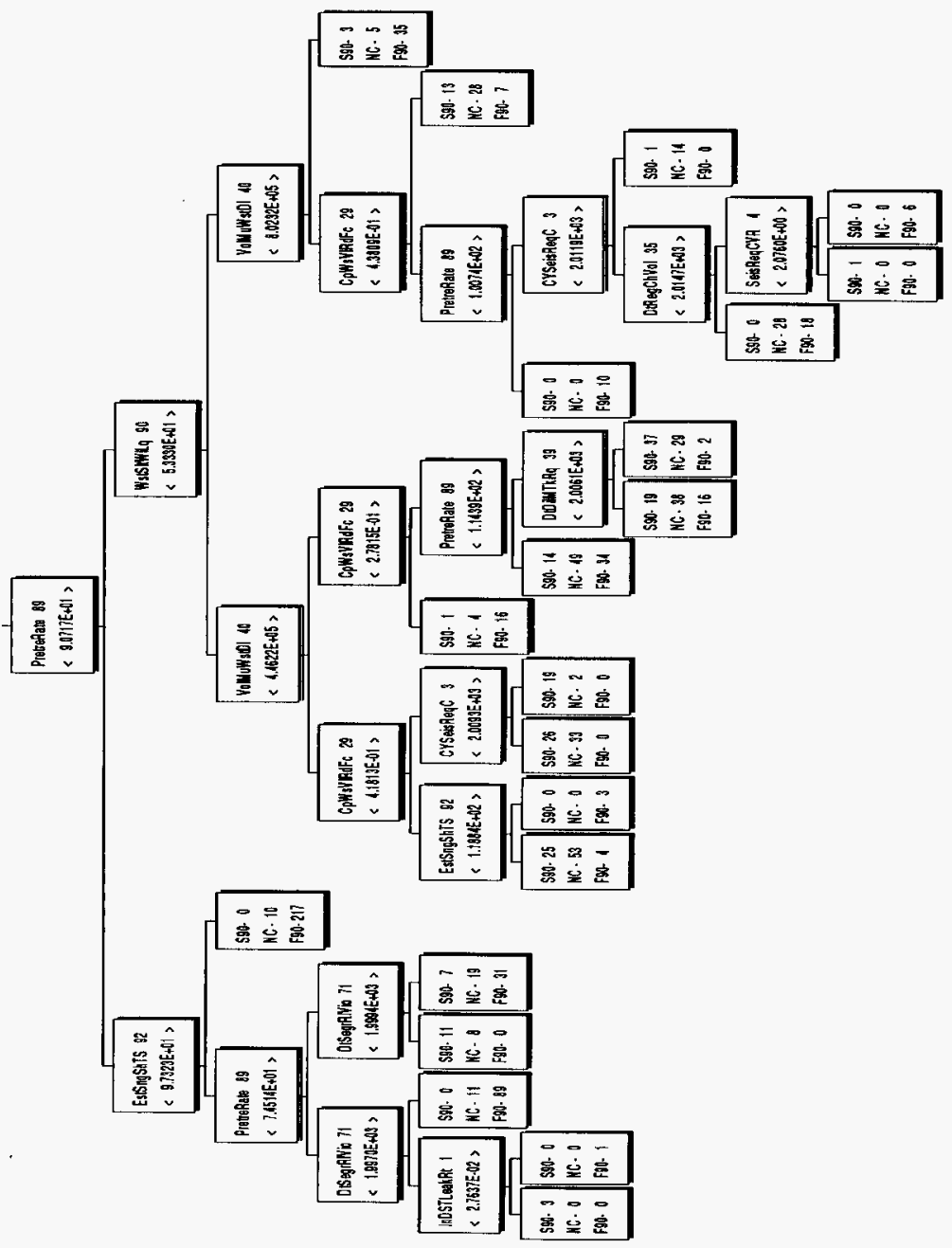


Figure 6-3. Variable Importance Tree Showing Variable Split Values for Aging Waste Without Fall-Back Positions.

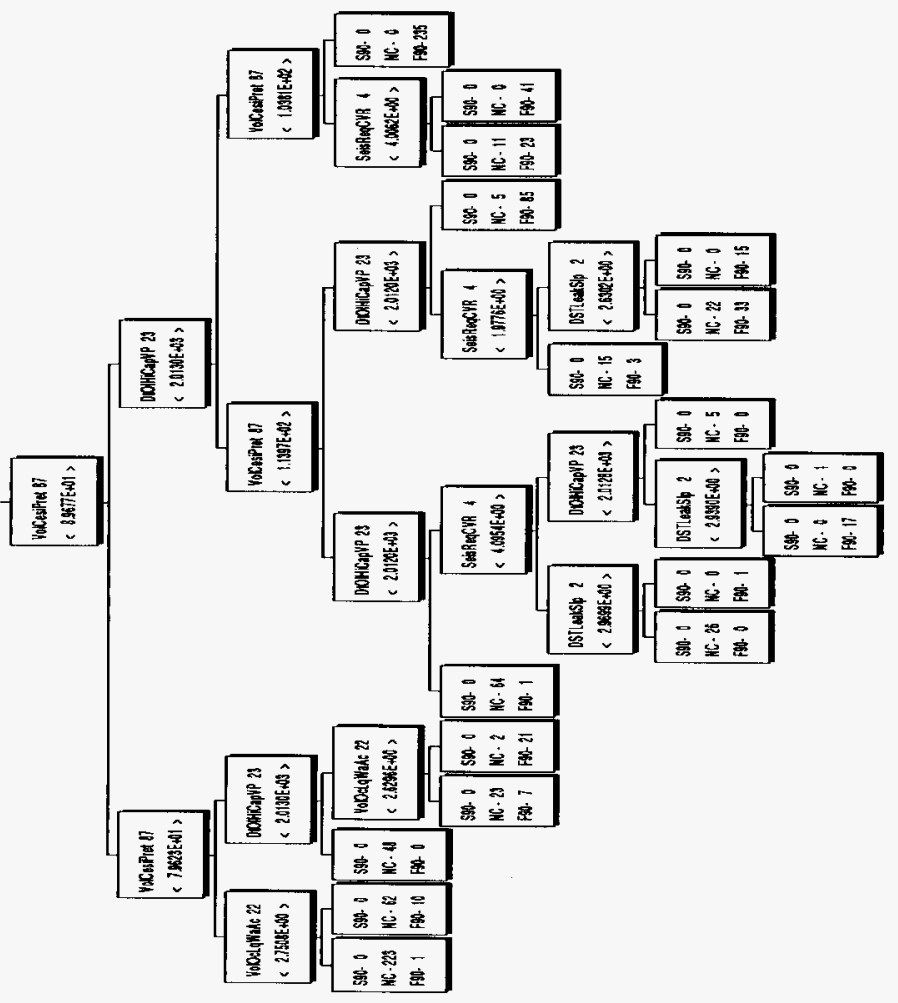


Table 6-3. Fall-Back Positions Ranked According to Their Effectiveness in Producing Successes. (fall-back variables activated)

\begin{tabular}{|c|c|c|c|c|l|}
\hline Var & $\begin{array}{c}\text { Rank } \\
\text { NCmplx }\end{array}$ & $\begin{array}{c}\text { Rank } \\
\text { Cmplx }\end{array}$ & $\begin{array}{c}\text { Rank } \\
\text { Aging }\end{array}$ & $\begin{array}{c}\text { Var } \\
\text { Type }\end{array}$ & \multicolumn{1}{|c|}{ Variable Description } \\
\hline 128 & 1 & 2 & 5 & $F$ & Decide generators must reduce volume \\
\hline 144 & 2 & 1 & 7 & $F$ & Decide to chemica 7 ly adjust incoming volume \\
\hline 107 & 3 & 4 & 8 & $F$ & Suspend saltwel1 pumping \\
\hline 116 & 4 & 7 & 4 & $F$ & Decide to use SSTs as temporary storage \\
\hline 132 & 5 & 8 & 6 & $F$ & Decide to build new tanks \\
\hline 124 & 6 & 3 & 2 & $F$ & Decide to store liguids in existing grout vaults \\
\hline 140 & 7 & 6 & 3 & $F$ & Decide to add waste to IMusT tanks \\
\hline 120 & 8 & 5 & 1 & $F$ & Decide to activate grout program \\
\hline
\end{tabular}

Note:

$F=$ Fall-Back Variable

Ncmplx = Noncomplexed Waste

Cmplx $=$ Complexed Waste

$\operatorname{Var}=$ Variable

$\mathrm{Cr}=$ Calendar Year 
Figure 6-4. Variable Importance Tree for Noncomplexed Waste Fall-Back Positions.

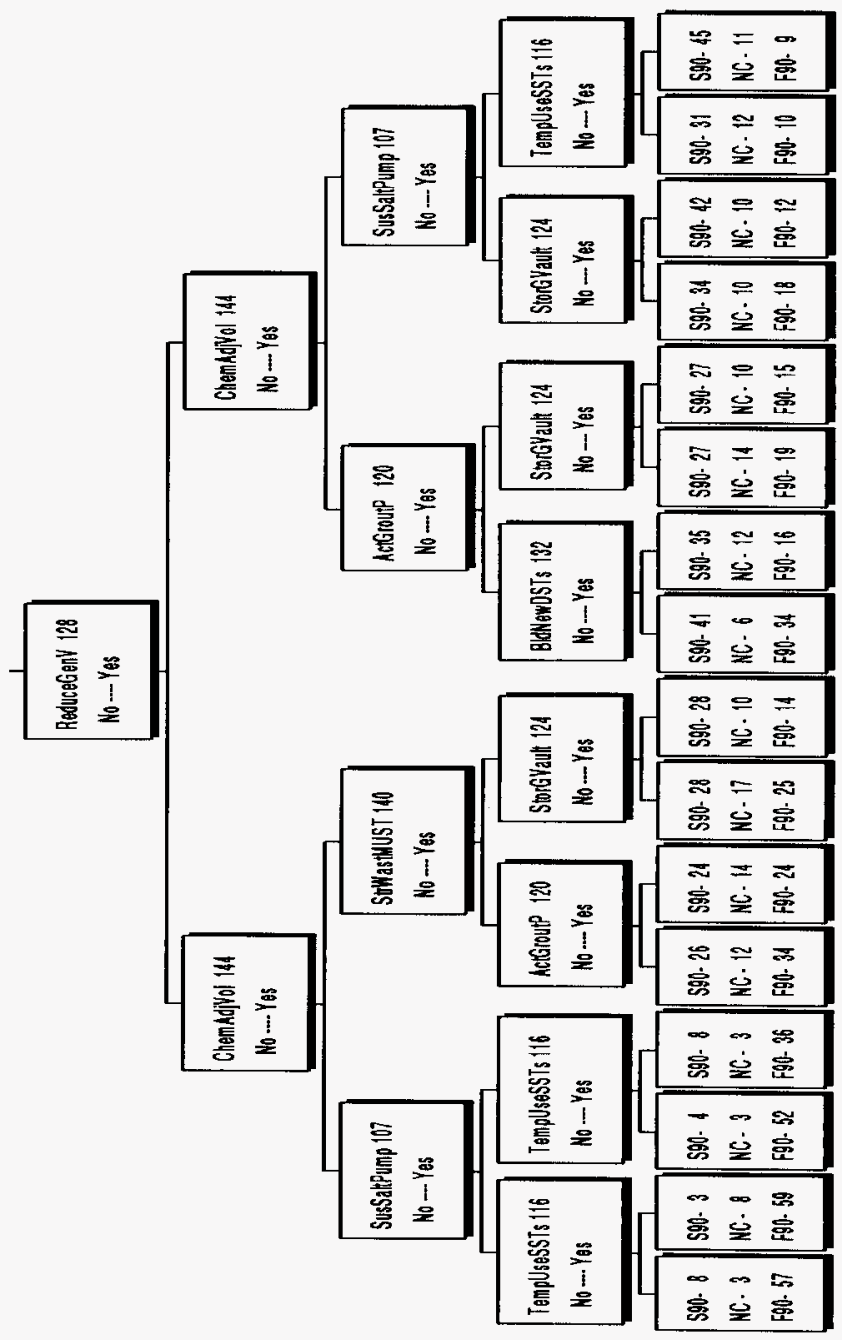


Figure 6-5. Variable Importance Tree for Complexed Waste Fal1-Back Positions.

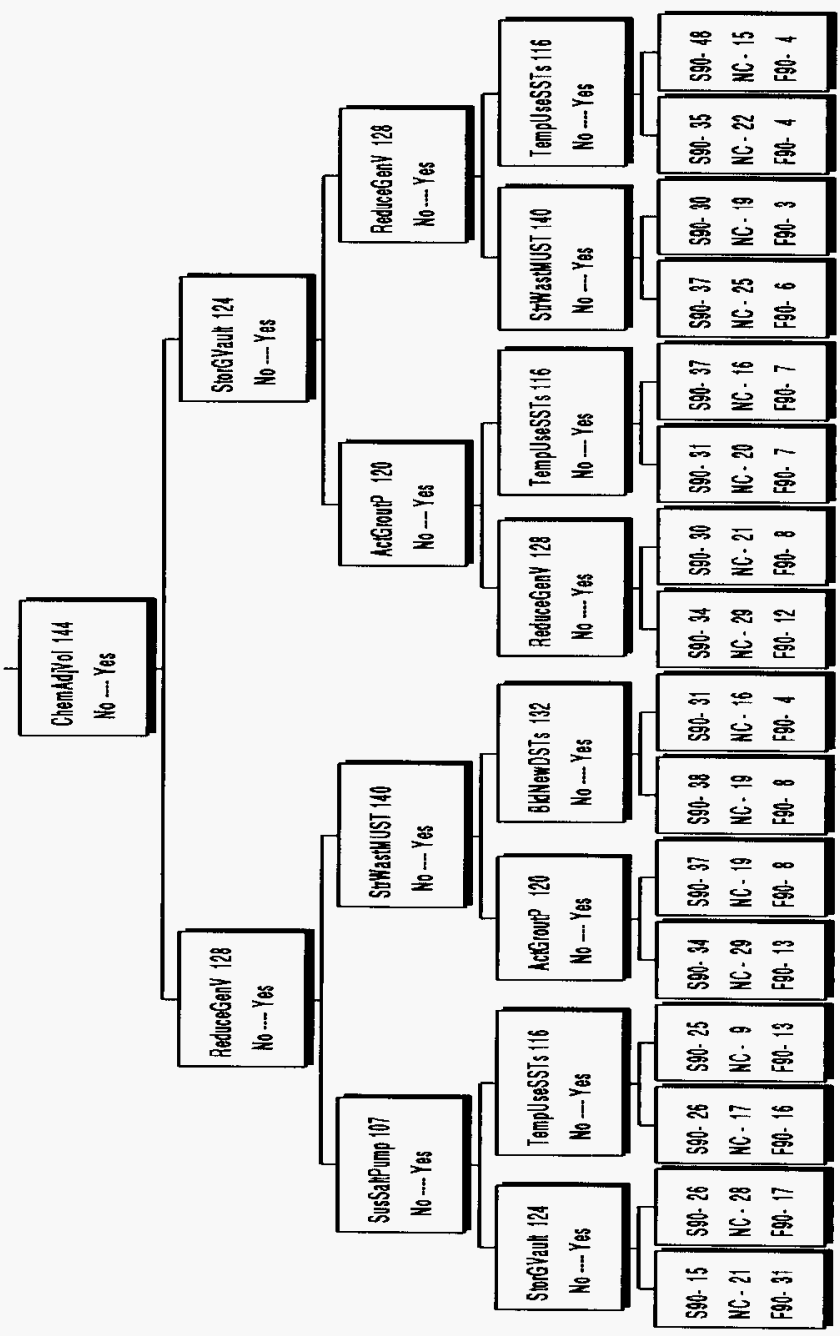


Figure 6-6. Variable Importance Tree for Aging Waste Fa11-Back Positions.

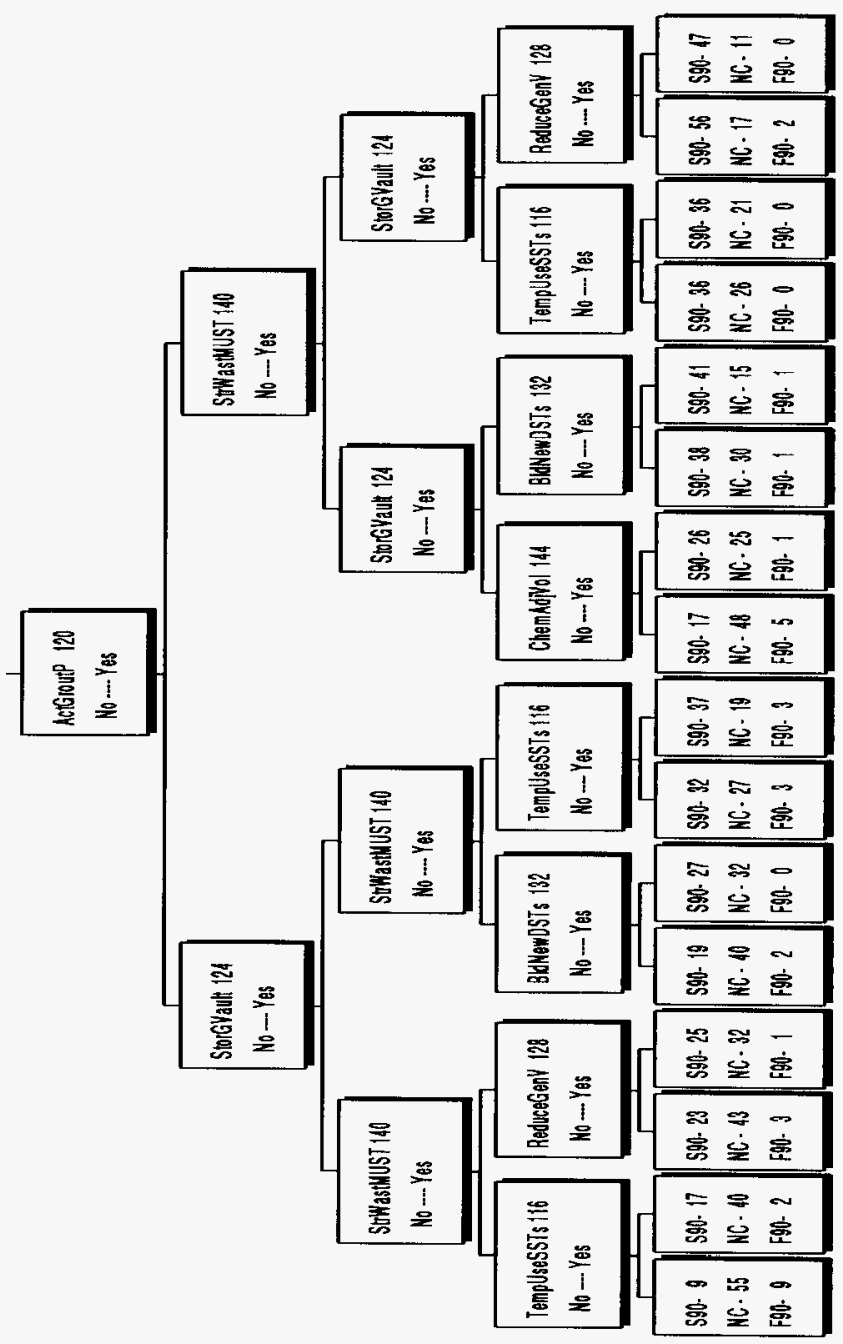


Tables 6-4 and 6-5 show the combined ranking of the off-normal events, the internal model variables, and the fall-back modeling variables for correlation cutoffs at 10 percent and 5 percent of the total variable effect on success or failure in containing the volumes of the three waste types. The 10 percent correlation cutoff results in 27 significant variables of which only 5 are internal model variables, 10 are off-normal events, and 12 are fall-back positions. Five of the 10 top-ranked variables are fall-back positions associated with reducing or postponing the volume of the waste generated.

Reducing the correlation cut-off to 5 percent increases the number of significant variables to 56, of which 9 are internal, 18 are off-normal, and 27 are fall-back variables. The 56 variables producing results greater than the 5 percent correlation value will be carried forward in future analysis.

Tank capacity performance for the three waste types differs markedly among the three waste types. As shown in Figure 6-7. the aging waste performance without fall-back positions is highly dependent on two variables: the volume of cesium to pretreatment and the on-line date of the vitrification facility. The tank capacity performance for the aged and complexed wastes is highly dependent only on the pretreatment rate.

Approximately six. second-rank variables affect the complexed waste performance while the noncomplexed waste has only two second rank variables with effects between 10 percent and 30 percent. The number of aging waste second rank variables is intermediate between the other two.

The introduction of fal1-back positions increases the number of most important variables by leveling the importance of the off-normal variables (i.e.. the importance difference between variables is reduced). Fall-back positions such as pretreatment rates that directly affect the system as a whole will aiways have large effects on tank capacity performance. When the performance is already dependent on a large number of second rank variables. fall-back positions that improve the working of the system internals will have a weaker effect than for the cases in which fewer second rank variables are present. 
Table 6-4. Variables Ranked According to their Correlation with Maximum Exceedence volume $(R>10 \%)$. (fall-back variables activated)

\begin{tabular}{|c|c|c|c|c|c|c|}
\hline Rank & Var & $\begin{array}{l}\text { Rank } \\
\text { NCmplx }\end{array}$ & $\begin{array}{l}\text { Rank } \\
\text { Cmplx }\end{array}$ & $\begin{array}{c}\text { Rank } \\
\text { Aging } \\
\end{array}$ & $\begin{array}{l}\text { Var } \\
\text { Type }\end{array}$ & Variable Description \\
\hline 1 & 128 & 1 & 11 & - & $F$ & Decide generators must reduce volume \\
\hline 2 & 89 & 2 & 4 & $--\cdot$ & I & Pretreatment rate (kgal) \\
\hline 3 & 144 & 3 & 9 & $-\cdot-$ & $\mathrm{F}$ & Decide to chemically adjust incoming volume \\
\hline 4 & 40 & 4 & 5 & $\cdots$ & 0 & Volume of MUST waste to dilute (gal) \\
\hline 5 & 92 & 5 & $\cdots$ & $\ldots$ & $!$ & East SST solids (kgal) \\
\hline 6 & 145 & 6 & - - & -- & $F$ & $\begin{array}{l}\text { Date of decision to chemically adjust to incoming } \\
\text { volume (CY) }\end{array}$ \\
\hline 7 & 129 & 7 & --- & $-\cdots$ & $\mathrm{F}$ & $\begin{array}{l}\text { Date of decision generators must reduce volume } \\
\text { (CY) }\end{array}$ \\
\hline 8 & 98 & 8 & $\cdots$ & $\cdots$ & I & East flush water (kgal) \\
\hline 9 & 131 & 9 & $-\ldots$ & $-\ldots$ & $F$ & Volume of generator volume reduction $(\%)$ \\
\hline 10 & 39 & 10 & 2 & $\ldots$ & 0 & Date dilution of MUSTs required (CY) \\
\hline 11 & 90 & 11 & 1 & $-\cdot$ & I & West saltwell irquid (porosity, kgal) \\
\hline 12 & 29 & $-\cdots$ & 7 & $\ldots$ & 0 & Complexed waste volume reduction factor \\
\hline 13 & 107 & -- & 10 & $\cdots$ & $\mathrm{F}$ & Suspend sal twell purnping \\
\hline 14 & 125 & $\cdots$ & 8 & 3 & $\mathrm{~F}$ & $\begin{array}{l}\text { Date of decision to store liquids in grout vaults } \\
\text { (CY) }\end{array}$ \\
\hline 15 & 116 & -- & $\ldots$ & 9 & $\mathrm{~F}$ & Decide to use SSTs as temporary storage \\
\hline 16 & 4 & -.- & 12 & 7 & 0 & $\begin{array}{l}\text { Seismic requirements change } \% \text { volume reduction } \\
48 " \text { impact }\end{array}$ \\
\hline 17 & 3 & $-\ldots$ & 3 & 10 & 0 & Date of seismic requirements change $(C Y)$ \\
\hline 18 & 71 &.-- & 6 & $-\cdots$ & 0 & Date of segregation rule violation (CY) \\
\hline 19 & 120 & $\ldots$ & $\cdots$ & 4 & $\mathrm{~F}$ & Decide to activate grout program \\
\hline 20 & 140 & $\cdots$ & $\cdots$ & 5 & $\mathrm{~F}$ & Decide to add waste to IMUSTs \\
\hline 21 & 124 & -- & 13 & 2 & $\mathrm{~F}$ & Decide to store liquids in existing grout vaults \\
\hline 22 & 22 & -- &.- & 8 & 0 & $\begin{array}{l}\text { Volumes occupied by liquid waste accumulation } \\
\text { (tanks) }\end{array}$ \\
\hline 23 & 121 & -- & --- & 6 & $F$ & Date of decision to activate grout program (CY) \\
\hline 24 & 24 & $\ldots$ & - & 1 & 0 & Authorization delay for NCAW consolidation (CY) \\
\hline 25 & 19 & $--\cdot$ & $-\cdot$ & 12 & 0 & Date privatization begins (CY) \\
\hline 26 & 1 & $\ldots$ & $--\cdot$ & 13 & 0 & Initial DST leak occurrence rate (1/yr) \\
\hline 27 & 87 & $-\cdots$ & $\ldots$ & 11 & 1 & Volume of cesium to pretreatment (kgal) \\
\hline
\end{tabular}

Notes:

$I=$ Internal Variable: $F=F a 11$-Back Variable; $0=0 f f-$ Normal Variable

Ncmplx = Noncomplexed Waste; Cmplx = Complexed Waste; Var = Variable; $\mathrm{CY}=$ Calendar Year 
Table 6-5. Variables Ranked According to their Correlation with Maximum Exceedence volume $(R>5 \%)$. (fall-back variables activated) (Sheet 1 )

\begin{tabular}{|c|c|c|c|c|c|c|}
\hline Rank & Var & $\begin{array}{l}\text { Rank } \\
\text { NCmplx }\end{array}$ & $\begin{array}{l}\text { Rank } \\
\text { Cmplx }\end{array}$ & $\begin{array}{l}\text { Rank } \\
\text { Aging }\end{array}$ & $\begin{array}{l}\text { Var } \\
\text { Type }\end{array}$ & Variable Description \\
\hline 1 & 128 & 1 & 11 & 21 & $\mathrm{~F}$ & Decide generators must reduce volume \\
\hline 2 & 89 & 2 & 4 & $\ldots$ & 1 & Pretreatment rate $(\mathrm{kgal})$ \\
\hline 3 & 144 & 3 & 9 & 15 & F & Decide to chemically adjust incoming volume \\
\hline 4 & 40 & 4 & 5 & $\ldots$ & 0 & Volume of MUST waste to dilute (ga?) \\
\hline 5 & 92 & 5 & 18 & $\ldots$ & 1 & East SST solids (kgal) \\
\hline 6 & 145 & 6 & -- & 24 & $\mathrm{~F}$ & $\begin{array}{l}\text { Date of decision to chemically adjust incoming volume } \\
\text { (CY) }\end{array}$ \\
\hline 7 & 129 & 7 & $-\ldots$ & $\ldots$ & $\mathrm{F}$ & Date of decision generators must reduce volume $(\mathrm{CY})$ \\
\hline 8 & 98 & 8 & $\ldots$ & $\ldots$ & I & East flush water (kgal) \\
\hline 9 & 131 & 9 & $-\ldots$ & $-\ldots$ & $\mathrm{F}$ & Volume of generator volume reduction $(\%)$ \\
\hline 10 & 39 & 10 & 2 & $\ldots$ & 0 & Date dilution of MUSTs required $(C Y)$ \\
\hline 11 & 90 & 11 & 1 & $\ldots$ & I & West saltwell liquid (porosity, kgal) \\
\hline 12 & 78 & 12 & 25 & $\ldots$ & I & Distribution for $\mathrm{N}$-Basin waste (gal) \\
\hline 13 & 37 & 13 & 14 &.-- & 0 & Date dissolution of safety tanks required $(\mathrm{CY})$ \\
\hline 14 & 29 & 14 & 7 & $-\ldots$ & 0 & Complexed waste volume reduction factor \\
\hline 15 & 38 & 15 & 21 & $\ldots$ & 0 & Dilution factor of MUSTs \\
\hline 16 & 95 & 16 & $\ldots$ & $\ldots$ & I & B-Plant (kgal) \\
\hline 17 & 107 & 17 & 10 & $\ldots$ & $\mathrm{F}$ & Suspend saltwell pumping \\
\hline 18 & 108 & 18 & 23 & 25 & $\mathrm{~F}$ & Date saltwell pumping suspended ( $\mathrm{CY}$ ) \\
\hline 19 & 146 & 19 & $\cdots$ & $\ldots$ & $\mathrm{F}$ & $\begin{array}{l}\text { Time to implement chemically adjust to incoming volume } \\
\text { (yr) }\end{array}$ \\
\hline 20 & 54 & 20 & $\ldots$ & $\ldots$ & 0 & Schedule delay per failure (yr) \\
\hline 21 & 125 & 21 & 8 & 3 & $\mathrm{~F}$ & Date of decision to store liquids in grout vaults (CY) \\
\hline 22 & 119 & 22 & $\ldots$ & $\ldots$ & $\mathrm{F}$ & Volume of SST temporary storage (tanks) \\
\hline 23 & 48 & 23 & 16 & $\ldots$ & 0 & Purex waste volume increase factor \\
\hline 24 & 147 & 24 & $\ldots$ & $\ldots$ & F & Chemically adjust volume reduction factor $(\%)$ \\
\hline 25 & 105 & $\ldots$ & 28 & $\ldots$ & $\mathrm{F}$ & Decide to use or build another facility \\
\hline 26 & 62 & $\ldots$ & 20 & $-\ldots$ & 0 & Date of replacement of government customer ( $\mathrm{CY}$ ) \\
\hline 27 & 116 & $\ldots$ & 29 & 9 & $\mathrm{~F}$ & Decide to use SSTs as temporary storage \\
\hline 28 & 4 & -- & 12 & 7 & 0 & $\begin{array}{l}\text { Seismic requirements change } * \text { volume reduction } 48 " \\
\text { impact }\end{array}$ \\
\hline 29 & 123 & $\cdots$ & $-\ldots$ & 16 & $\mathrm{~F}$ & Volume of SST temporary storage (tanks) \\
\hline 30 & 3 & $\ldots$ & 3 & 10 & 0 & Date of seismic requirements change $(C Y)$ \\
\hline 31 & 127 & $-\ldots$ & 30 & $\ldots$ & $\mathrm{F}$ & Volume of temporary storage grout vaults (tanks) \\
\hline 32 & 85 & $-\cdots$ & $\ldots$ & 29 & I & Minimum fraction of waste to pretreatment facility \\
\hline 33 & 143 & $\ldots$ & -- & 19 & $\mathrm{~F}$ & Volume of added waste to IMUSTs (tanks) \\
\hline 34 & 71 & $-\cdots$ & 6 & 17 & 0 & Date of segregation rule violation $(\mathrm{Cr})$ \\
\hline
\end{tabular}


Table 6-5. Variables Ranked According to their Correlation with Maximum Exceedence Volume $(R>5 \%)$. (fall-back variables activated) (Sheet 2)

\begin{tabular}{|c|c|c|c|c|c|c|}
\hline Rank & Var & $\begin{array}{l}\text { Rank } \\
\text { NCmplx }\end{array}$ & $\begin{array}{l}\text { Rank } \\
\text { Cmplx }\end{array}$ & $\begin{array}{l}\text { Rank } \\
\text { Aging }\end{array}$ & $\begin{array}{l}\text { Var } \\
\text { Type }\end{array}$ & Variable Description \\
\hline 35 & 120 & $\cdots$ & 17 & 4 & $\mathrm{~F}$ & Decide to activate grout program \\
\hline 36 & 101 & $-\cdots$ & $-\cdots$ & 23 & I & Dilute DST waste (kgal) \\
\hline 37 & 81 & --- & 15 & $-\cdots$ & 1 & Percent Complexed SST Solids \\
\hline 38 & 73 & $\ldots$ & $\ldots$ & 26 & 0 & Date of tank NDE effects (CY) \\
\hline 39 & 109 & $-\cdots$ & 31 & $\cdots$ & $\mathrm{F}$ & Duration of saltwell pumping suspension (yr) \\
\hline 40 & 140 & $\cdots$ & $\cdots$ & 5 & $\mathrm{~F}$ & Decide to add waste to IMUSTs \\
\hline 41 & 64 & $\ldots$ & 26 & $\cdots$ & 0 & Date of stoppage due to system engineering defect (CY) \\
\hline 42 & 133 & $\ldots$ & $\ldots$ & 14 & $F$ & Date of decision to build new tanks (Cy) \\
\hline 43 & 124 & - & 13 & 2 & $F$ & Decide to Store Liquids in existing grout vauits \\
\hline 44 & 23 & $\cdots$ & -- & 27 & 0 & $\begin{array}{l}\text { On-1ine date of high capacity vitrification facility } \\
\text { (CY) }\end{array}$ \\
\hline 45 & 22 & $-\ldots$ & 22 & 8 & 0 & Volumes occupied by liquid waste accumulation (tanks) \\
\hline 46 & 132 & $\ldots$ & $\ldots$ & 28 & $\mathrm{~F}$ & Decide to build new tanks \\
\hline 47 & 121 & $\cdots$ & 19 & 6 & $\mathrm{~F}$ & Date of decision to activate grout program (CY) \\
\hline 48 & 50 & $\ldots$ & 27 & -- & 0 & Date of discovery of old waste $(C Y)$ \\
\hline 49 & 24 & $\cdots$ & -- & 1 & 0 & $\begin{array}{l}\text { Authorization delay for NCAW } \\
\text { consolidation (CY) }\end{array}$ \\
\hline 50 & 19 & $-\cdot-$ & $-\ldots$ & 12 & 0 & Date privatization begins ( $\mathrm{CY}$ ) \\
\hline 51 & 118 & $\cdots$ & -- & 22 & $F$ & $\begin{array}{l}\text { Delay for public approval of SST as temporary storage } \\
\text { (yr) }\end{array}$ \\
\hline 52 & 117 & $-\cdots$ & $-\ldots$ & 18 & F & Date of decision to use SSTs temporary storage (CY) \\
\hline 53 & 58 & $-\cdot$ & 24 & -- & 0 & Date of contractor changeover (CY) \\
\hline 54 & 141 & $\cdots$ & $\cdots$ & 20 & $\mathrm{~F}$ & $\begin{array}{l}\text { Date of decision added waste to IMUSTs } \\
\text { (CY) }\end{array}$ \\
\hline 55 & 1 & $-\ldots$ & -- & 13 & 0 & Initial OST leak occurrence rate $(1 / \mathrm{yr})$ \\
\hline 56 & 87 & $\ldots$ & $-\ldots$ & 11 & I & Volume of cesium to pretreatment (kgal) \\
\hline
\end{tabular}

Notes:

$I=$ Internal Variable: $F=F a 11$-Back Variable; $0=$ Off-Normal Variable Ncmplx = Noncomplexed Waste: Cmplx = Complexed Waste: Var = Variable: $c y=$ Calendar Year 
The validity of selecting important variables across waste catagories (combined ranking) can be formalized by Kendall's coefficient of concordance $w$ (Sprent 1975). The coefficient $w$ can vary between zero (no concordance between catagories) to one (a)1 catagories have identical ranking). Table 6-6 shows $w$ computed for waste types taken two and three at a time. Without fall-back positions. the ranking of variables affecting complexed and noncomplexed waste are the most similar. This is intuitive because variables such as SST retrieval volume and pretreatment rate both have a large influence on storage of noncomplexed and complexed waste. A weaker concordance exists between storage of solids in aging waste tanks and the other waste types. The ranking of fall-back variables show a similar concordance in their influence across different waste types.

Table 6-6. Kendall's Coefficient of Concordance.

\begin{tabular}{|l|l|l|}
\hline & \multicolumn{1}{|c|}{ No Fall-Backs } & \multicolumn{1}{|c|}{ Fall-Back Variables } \\
\hline C-NC & 0.67 & 0.88 \\
\hline C-A & 0.51 & 0.40 \\
\hline NC-A & 0.45 & 0.32 \\
\hline C-NC-A & 0.39 & 0.38 \\
\hline$C=$ Complexed & \\
NC $=$ Noncomplexed & & \\
A $=$ Aging &
\end{tabular}




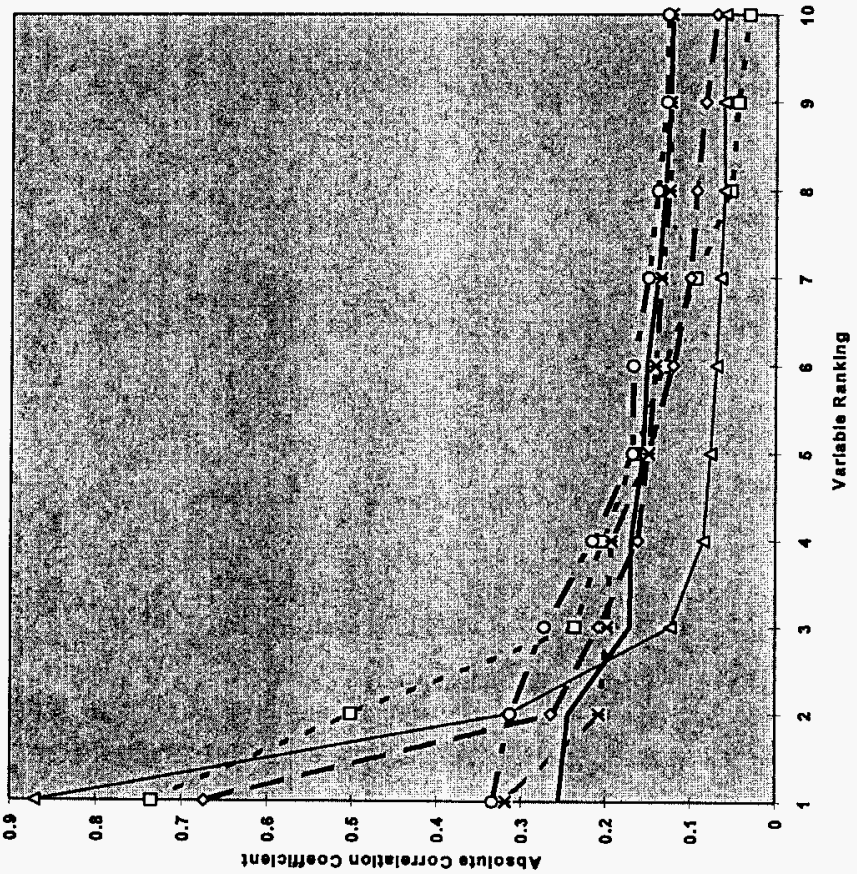

ㅎ
0
$\frac{5}{3}$
둔 


\subsection{CONCLUSIONS}

Based on the sensitivity analysis the importance ranking of the variables associated with off-normal events, and internal model variables, and programmatic changes was determined. A reduced set of the highest impact variables can now be the focus of available resources in establishing their technical bases and performing subsequent analyses.

Periods of tank capacity vulnerability were calculated at 80 percent. 90 percent, and 99 percent confidence levels. Figures 7-1 to 7-6 show the population binning of the sensitivity runs into successes and failures at the various confidence levels with and without fall-backs. The 99 percent confidence level presents the most severe test for defining successes and failures. For early years. the entire population results in successes for all waste types. Storage of noncomplexed waste shows an early reduction in successes just before $\mathrm{Cr} 2000$ that is likely due to the variability of incoming saltwell liquid. The storage of the other waste types show a rapid decrease in success just before $\mathrm{Cr} 2005$ when LLW pretreatment comes on-line. Storage of complexed waste rises in successes briefly after $C y$ 2005, but along with the other waste types shows increasing number of failures after CY 2009 when SST retrieval generates its largest volume of waste.

The figures in this section should be compared with those of Section 9.0 to understand the effect of using variable distributions more closely representative of the newest OWVP report to be issued later this year.

The choice of particular fall-back positions to alleviate vuinerable tank capacity periods requires further analyses with the following emphasis: 1) the technical bases for these problem variables must be established and accepted so the resultant uncertainties are correct and 2) the problem variables must be run with various fall-back position groupings to determine alternative choices.

Only after technical bases for the high impact variables are established and accepted can recommendations of fall-back positions for implementation be made. Only provisional and qualified suggestions may be made based on the sensitivity analyses. With this understanding the following preliminary suggestions of possible fall-back positions are outlined below.

- Evaluate novel waste reducing technologies for implementation in the years before high-capacity LLW processing.

- Establish plans for allowing transfer of two noncomplexed waste tanks for use as aging waste tanks by year 2007.

- Ensure the capacity of LLW pretreatment is sufficient to process the large volumes of waste introduced by SST retrieval.

Finally, an uncertainty-based approach to tank waste volume versus capacity was successfully demonstrated with a full complement of variables representing potential off-normal events and programmatic changes, along with tank system items. These variables are operational in a flexible modeling platform that can accept variable range distributions that can be probabilistically sampled automatically. Thus. this tool represents a strategic planning tool that quantifies tank waste system uncertainties and will aid in future decision making. 
Figure 7-1. Success of Aging Tank Waste Containment with No Fall-Back Acation (NFB).

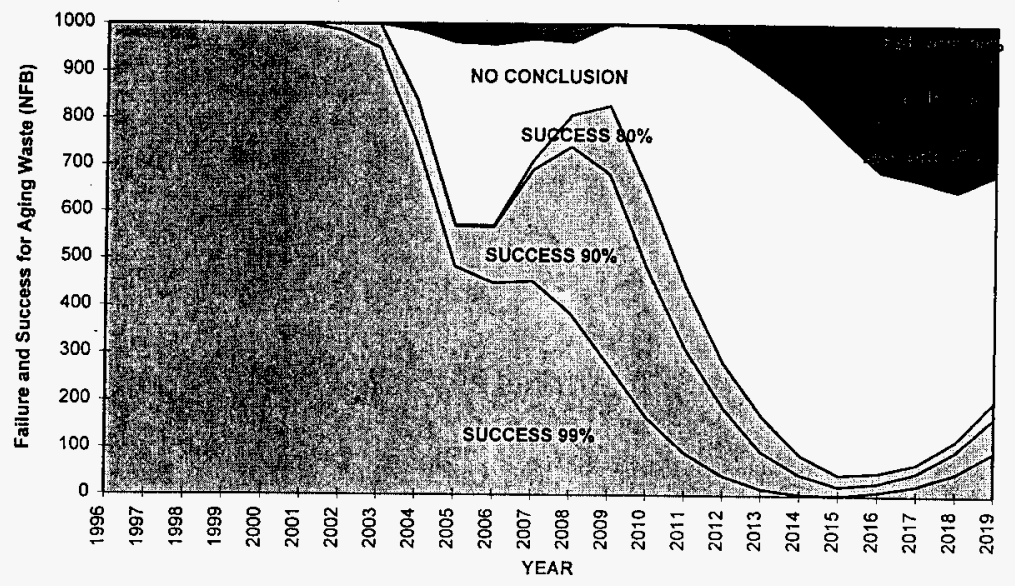

Figure 7-2. Success of Aging Tank Waste Containment with Fall-Back Action (FB).

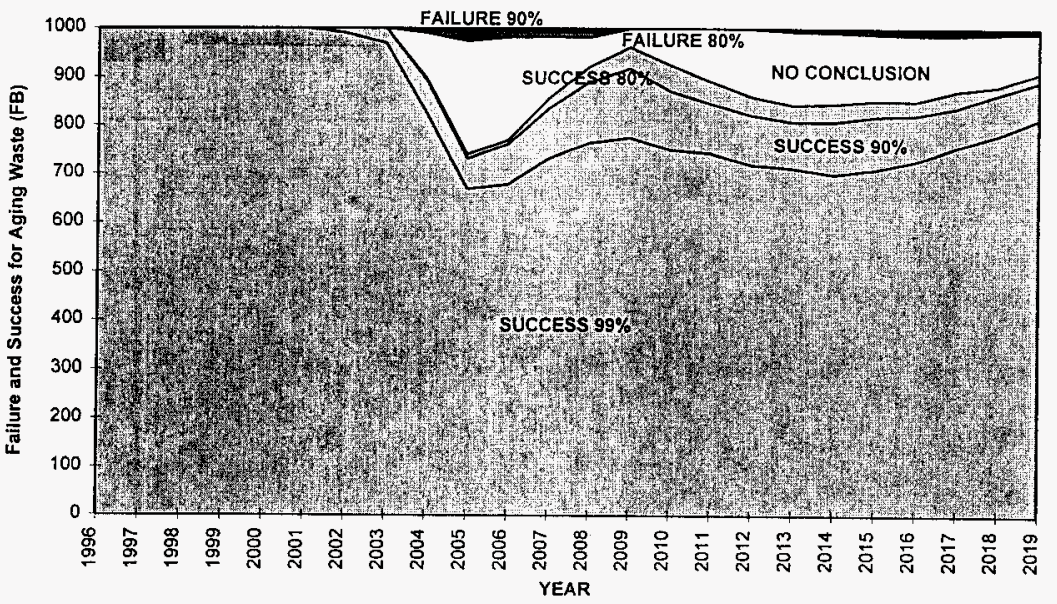


Figure 7-3. Success of Complex Tank Waste Containment with No Fall-Back Action (NFB).

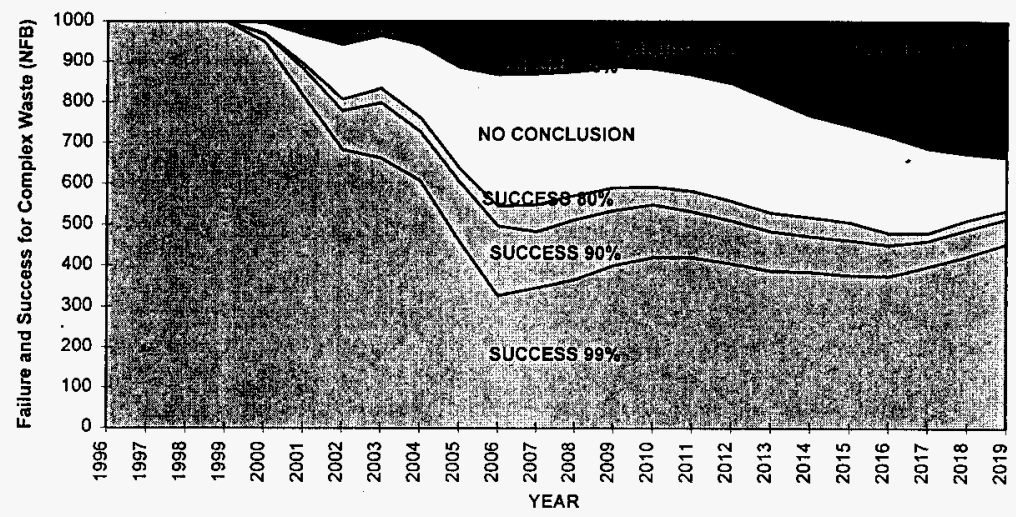

Figure 7-4. Success of Complex Tank Waste Containment with Fall-Back Action (FB).

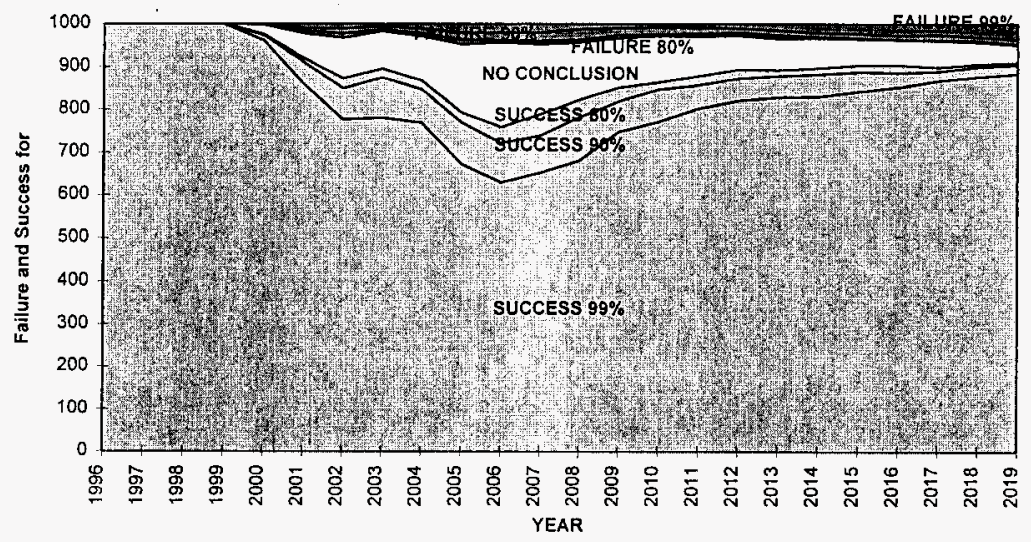


Figure 7-5. Success of Noncomplex Tank Waste Containment with No Fall-Back Action (NFB).

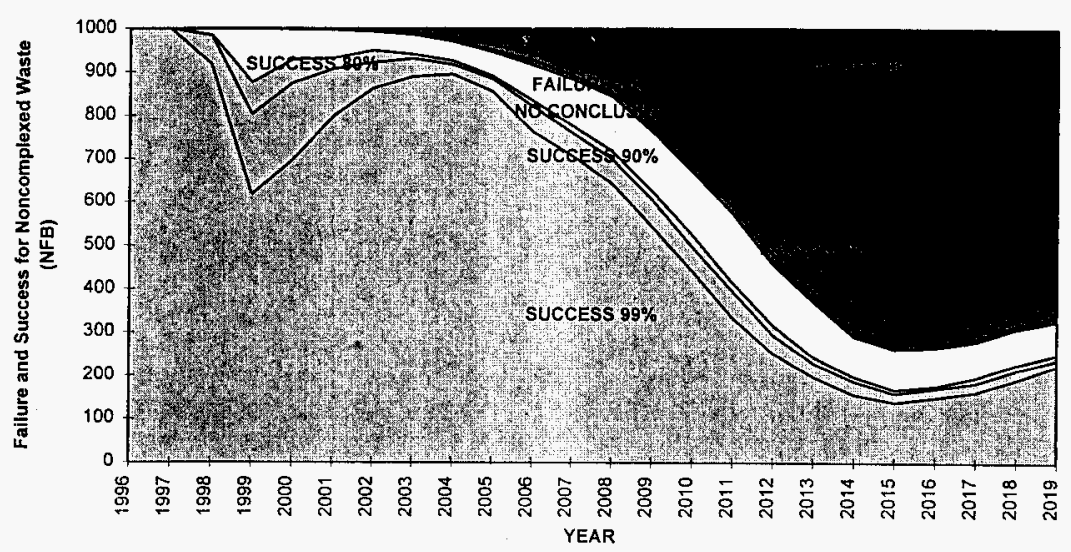

Figure 7-6. Success of Noncomplex Tank Waste Containment with Fall-Back Action (FB).

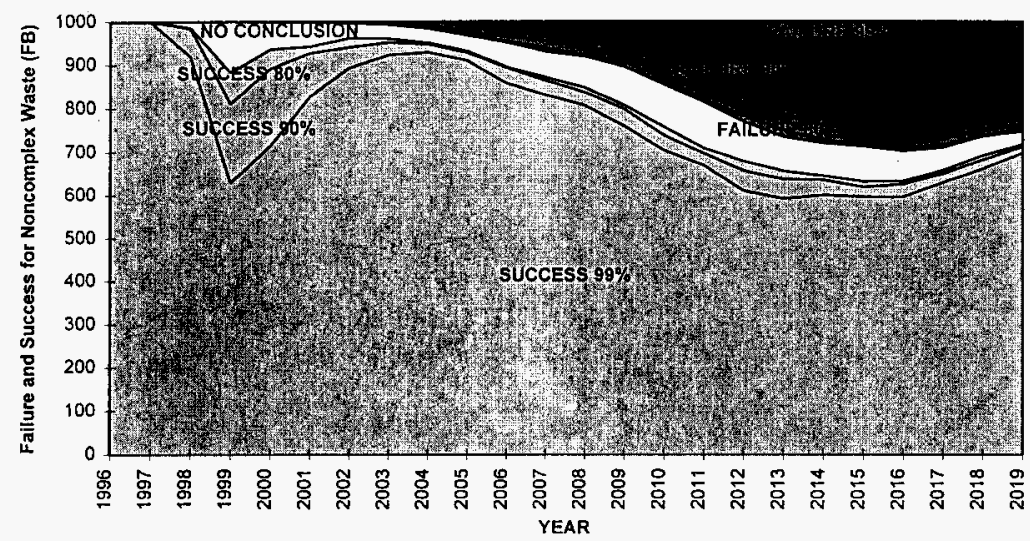




\subsection{RECOMMENDATIONS}

Several model improvements are being planned to further enhance representation of the tank system uncertainties. Some improvements include:

- Expansion of the model to represent individual tanks versus tank waste type.

- Incorporation of tank operation and retrieval scheduling information.

- Addition of realistic probability functions for DST system and tank availability.

In addition, the improvements plan includes the integration of this fall-back analysis model with the existing SIMAN retrieval and disposal model (Caprio 1995) to provide a risk-based strategic planning too?. The goal is to develop an integrated dynamic simulation tool that provides operational WVPS with confidence levels. that models waste retrieval, pretreatment, and disposal, and includes privatization assumptions along with a probabilistic treatment of potential tank system events (off-normal, programmatic, etc.). 
WHC-SD-WM-ER-548 Rev. 0

This page intentionally left blank. 
WHC-SD-WM-ER-548 Rev. 0

\subsection{NOTES ADDED IN REVIEW}

The following section is added to address review comments associated with current planning assumptions that differ from the Operational Waste Volume Projections (OWVP Rev. 21) [Strode and Koreski 1995] used for this report. The newest assumptions are driven by design specifications for privatization of disposal operations for both low-activity and high-level waste vitrification. A notable example is that the previously assumed $200 \mathrm{kgal} / \mathrm{year}$ of eluted Cesium from lowactivity waste pretreatment will not be returned to the aging waste double shell tanks. The actual returned volume should contain only entrained solids removed from the initial feed and is likely to be about 100 times smaller.

To assess the impact of these changing assumptions a few distribution ranges and model values were adjusted to more closely represent the expectation of knowedgable reviewers. Table 9-1 shows the distribution ranges and model values used to recompute figures of Section 7 . Note that these adjustments reflect only a preliminary step to establish the current model assumptions and parameter distributions representative of experts. Further work will capture the present state of knowledge for each variable listed in Appendix A to determine valid uncertainty ranges. Only then will it be appropriate to combine run sets probabilistically to predict the likelihood for insufficient waste storage capacity.

Table 9-1. Adjusted Variable Distribution Ranges and Model Values.

\begin{tabular}{|l|l|l|}
\hline \multicolumn{1}{|c|}{ Variable Description } & \multicolumn{1}{|c|}{ Distribution } & \multicolumn{1}{c|}{ Value Range } \\
\hline $\begin{array}{l}\text { C-106 Addition to Aging Waste Tanks } \\
\text { (kgal) }\end{array}$ & Single Value & 400.0 \\
\hline Dilution Factor of MUSTs & UNIFORM & 1.0 to 2.0 \\
\hline $\begin{array}{l}\text { Volume of Cesium to Pretreatment } \\
\text { (kga } / \text { yr) }\end{array}$ & UNIFORM & 1.0 to 1.5 \\
\hline West Saltwell Liquid (porosity, kgal) & UNIFORM & 25.0 to 40.0 \\
\hline Number of New Tanks & UNIFORM & 2.0 to 20.0 \\
\hline
\end{tabular}

The greatest effect resulting from the modified ranges in Table 9-1 are for the aging waste storage tanks. Since a significant waste source (eluted Cesium returns) is effectively eliminated. Figure 9-3 shows only a small fraction of the runs not resulting in success. As expected, the small reduction in successes occurs just before operation of high-level waste vitrification in Cy 2010. Also, the introduction of fall-back positions has largely no effect on the aging waste tanks. However. the appearance of a few failures is possibly an artifact of introducing additional uncertainty through the fall-back variables. These few failures cout of 1.000 ) do not imp?y that fall-back positions are detrimental to storage in aging waste tanks.

Figures 9-1 and 9-2 are qualitatively similar to their corresponding figures in Section 7 . Once again a mild decrease in successes for noncomplexed waste around $\mathrm{CY}$ 1998 results from the uncertainty in the SST saltwell liquids. The stronger 
reduction of successes for both complexed and noncomplexed waste in later years results from the increased rates of SST retrieval and the greater uncertainty in availibility of DST storage. The fall-back positions greatly influence the complexed and noncomplexed waste storage capability. A full assessment of the influence of each fall-back position taken independently is planned for a future study that more closely represents the waste storage considerations introduced by the Phase I and Phase II privatization. 
Figure 9-1. Success of Noncomplex Tank Waste Containment with Fal1-Back Action (FB).

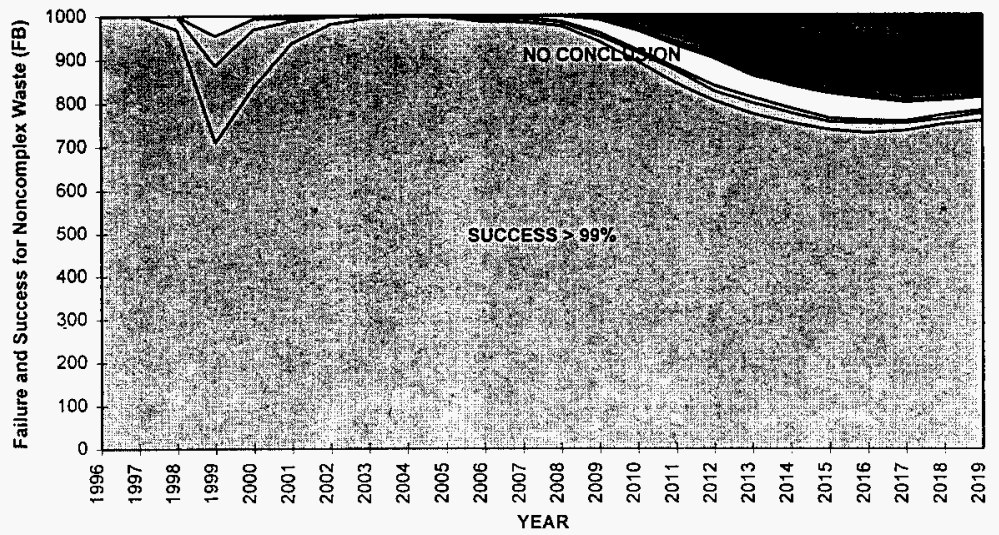

Figure 9-2. Success of Noncomplex Waste Containment with No FallBack Action (NFB).

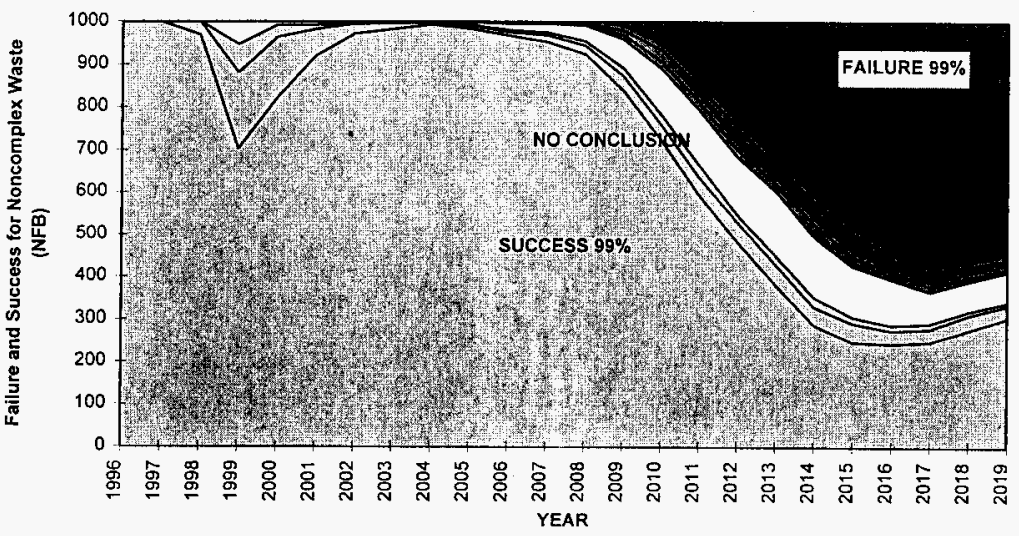


Figure 9-3. Success of Complex Tank Waste Containment with Fall-Back Action (FB).

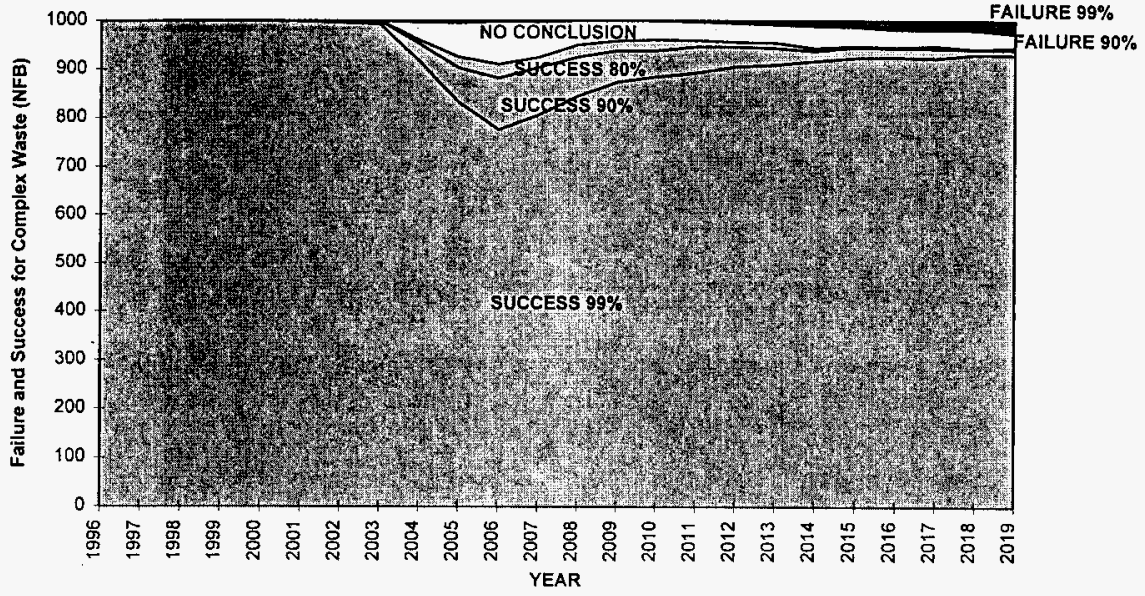

Figure 9-4. Success of Complex Tank Waste Containment with No Fal1-Back Action (NFB).

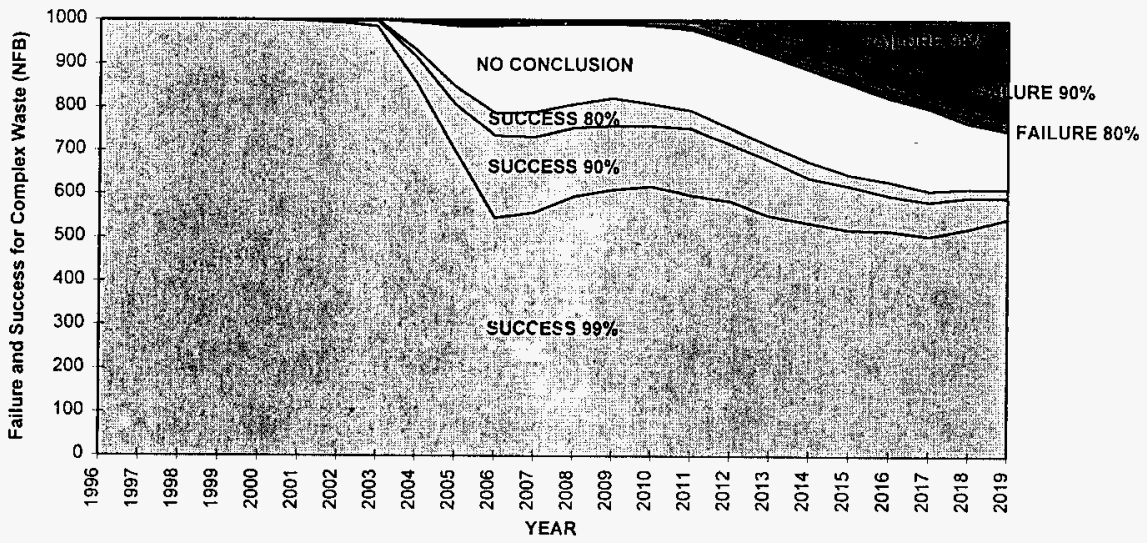


10
Failure and Success for Aging Waste (NFB)

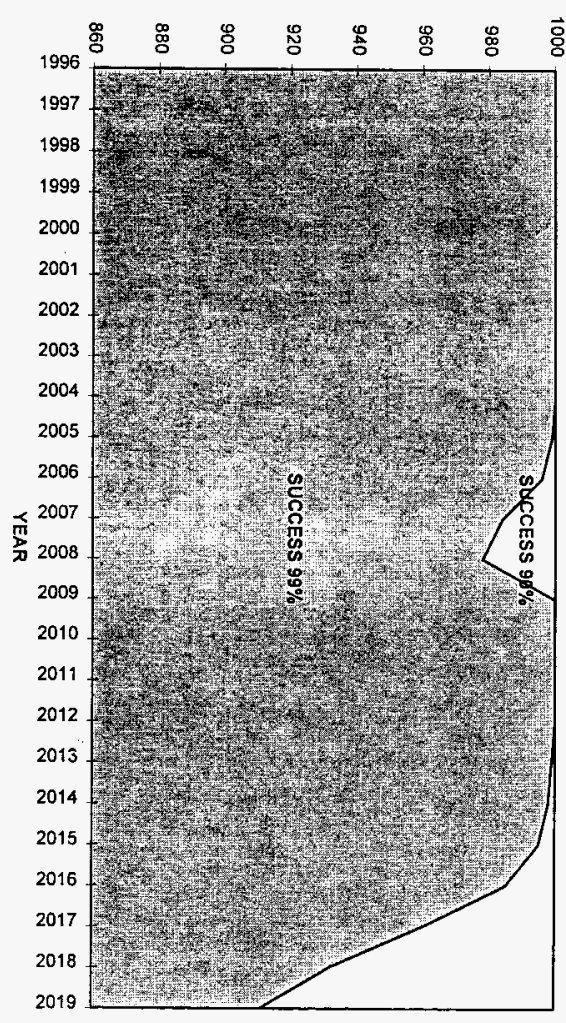

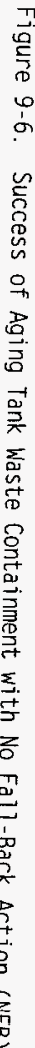

Failure and Success for Aging Waste (FB)

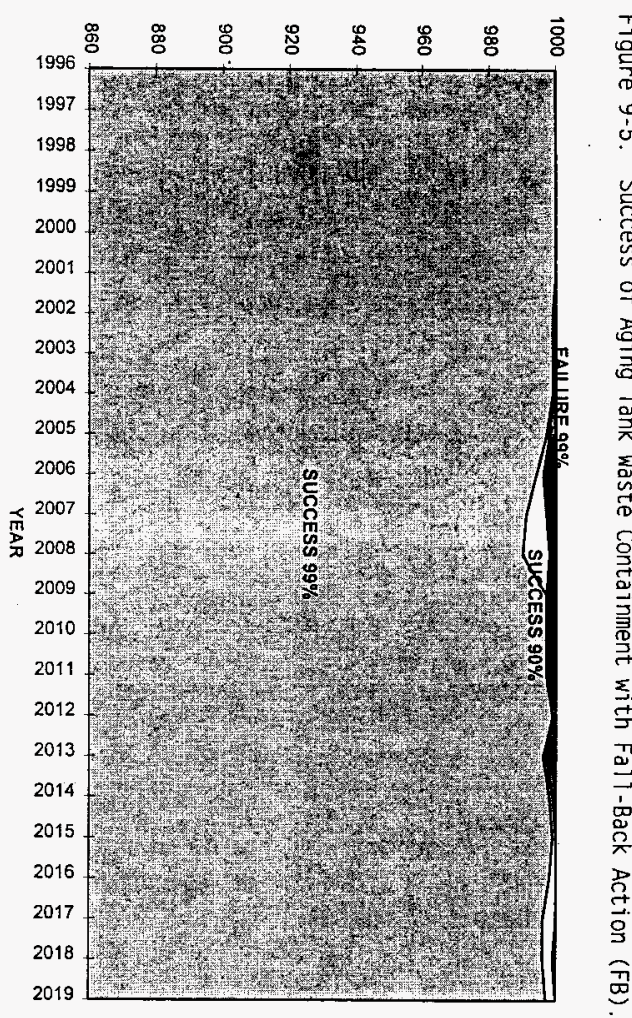

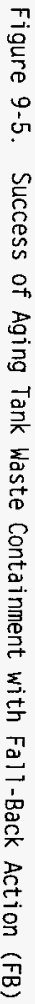

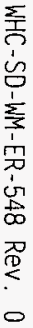


WHC-SD-WM-ER-548 Rev. 0

This page intentionally left blank. 


\subsection{REFERENCES}

Awadalla. N.G., 1995. Risk Management Workshop Paper, paper for brainstorming session held June 28. 1995. Westinghouse Hanford Company. Richland. Washington.

Caprio, G.S., 1995, Vapor and Gas Sampling of Single-Shel7 Tank 241-S-112 Using the Vapor Sampling System, WHC-SD-WM-RPT-176, Westinghouse Hanford Company. Richland. Washington.

Hanlon. 1995. Hanford Waste Tank Summary Report for the Month Ending June, 1995, WHC. EP-0182-84. Westinghouse Hanford Company, Richland, Washington.

Iman. Ronald L. and Michael Shortencarier. 1984. A FORTRAN 77 Program and User's Guide for the Generation of Latin Hypercube and Random Samples for Use with Computer Models". NUREG/CR-3624, Sandia National Laboratories.

Iman. Ronald L. and Jon C. Helton, 1987. An Investigation of Uncertainty and Sensitivity Analysis Techniques for Computer Models, in the magazine Risk Analysis, Vol. 8 pp. $71-89$.

Jansen. G. And D.H. Lester. 1988. Post-Closure Performance Analysis of Waste Packages in a High-Leve7 Nuclear Waste Repository. Paper 64C (Microfiche No. 30), 131st National Meeting of the AIChE, August 21-24, Denver, Colorado.

Jensen. C.E. 1995. Multi-Function Waste Tank Facility Phase Out Basis, WHC-SD-W236A-ER-021, Rev. 3. Westinghouse Hanford Company. Richland, Washington.

Korn, G.A.. and T.M. Korn, 1961, Mathematical Handbook for Scientists and Engineers. McGraw-Hi 11 Book Co.

Leach, C. E., and S. M. Stahl, 1993. Hanford Site Tank Farm Facilities Interim Safety Basis, WHC-SD-WM-ISB-001. Westinghouse Hanford Company, Richland. Washington.

Orme. R. M. . 1995. Informal Working Notes Clarifying Details Inferred From the Operational Waste Volume Projections.

Powe17. W.A. 1995. NCAW Consolidation Management P7an, WHC-SD-WM-ER-532 Revision 1, Westinghouse Hanford Company. Richland, Washington.

Russe17, E.L., G. Jansen, and W.V. Harper. 1988. Sensitivity Studies of the Waste Package - Near Field Subsystem. Vol. 2. pp. 627-632. Proceedings of the Symposium on Waste Management, February 28-March 3, Tucson. Arizona.

Sprent. P. 1975, Quick Statistics: An Introduction to Non-Parametric Methods, Penguin Books.

Strode, J.N. and G.M. Koreski. 1995, Operationa7 Waste Volume Projection, WHC-SD-WMER-029. Revision 21. Westinghouse Hanford Company. Richland, Washington. 
Thomas, Ralph E. and Roger W. Cote, 1983. Methodology for Predicting the Life of Waste-Package Materials and Components Using Multifactor Accelerated Life Tests, ONWI-501, Battelle Memorial Institute, Columbus Ohio.

Thurkow. T.J., R.L. Fritz, and G.A. Cole, 1995, A Risk Management Approach to DoubleShe 71 Tank Waste Volume Versus Storage Capacity. WHC-SD-WM-ER-527, Revision 0. Westinghouse Hanford Company, Richland. Washington.

WHC. 1995. Tank Waste Remediation System FY 1996 Multi-Year Program Plan. Westinghouse Hanford Company. Richland, Washington.

Zimmerman. B.D. . G. Jansen, and M.J. Moen. 1990. Three Applications of Rule Induction Expert Systems. WHC-EP-0323. Westinghouse Hanford Company, Richland, Washington. 
WHC-SD-WM-ER-548 Rev. 0

\section{GLOSSARY/INDEX}

\section{TERM}

ARES

capacity vulnerability

design point

deterministic projection

expert system code

industrial accident(s)

loguniform distribution

\section{DEFINITION}

the name of the company that produced the report containing the tank failure model.

the chance of not having enough tank volume to contain the liquid waste.

the single set of conditions that describe a working system.

the result of a model calculation that uses fixed values of all parameters instead of assuming that the values are uncertain with a probability distribution.

a computer program that can mimic the results of a calculation by a set of rules that relate the inputs to the output without actually knowing the mechanism that created the results.

any accident that occurs while operating an industrial plant.

a probability distribution with constant frequency over the logarithm of the range of occurrence.

\section{LOCATION}

1.2. 1.3. 3.0. 4.1.4.2,

5.0. Appendix C

7.0. 3.0, 1.1. Summary

$1.3,4.3$

1.1

1.3

4.3. Appendix A

$4.3,1.3$

GL-1 
WHC-SD-WM-ER-548 Rev. 0

\section{GLOSSARY/INDEX}

TERM

mitigating actions

off-normal conditions

pretreatment

physics analog

population binning

probability distribution

programmatic change events

sensitivity analysis
DEFINITION

actions taken to try to

avoid or lessen an

unwanted result.

events, usually unwanted. that are expected to happen but which do not contribute toward the goals of the planned operation.

modification of the waste before treatment.

Treatment is defined as conversion of the waste to its final form for disposal.

the physical description of a mathematical model.

counting the number of events that fall within predetermined limits.

the frequency of occurrence of events normalized to the total number of events.

a change in the DOE program that affects the risk of the waste volume exceeding the tank capacity.

varying the independant variables to identify which ones affect the answer the most.

\section{LOCATION}

\section{3}

4.1, 4.2, 4.3. Appendix $C$. 'Appendix $E$
$1.1,3.1,4.0,6.1,6.2$. 7.0. 8.0. Appendix A. Appendix $C$. Appendix $D$

Summary

Summary, 3.0, 7.0 
WHC-SD-WM-ER-548 Rev. 0

\section{GLOSSARY/INDEX}

TERM

straight Monte Car1o

structured Monte Carlo

tertiary effects

triangular distribution

uniform distribution

vitrification facility
DEFINITION

LOCATION

random sampling of the

2.4

results of a calculation.

a specific procedure for getting random results. usually in an especially efficient manner.

effects that are less important than already existing secondary or primary effects of the variable on the results.

the distribution of a population that has a single maximum value connected by straight lines to both ends of the range.

a probability distribution 1.3.4.3 with constant frequency over the entire range of occurrence.

a facility for converting liquid waste to glass for its final disposal form
2.1. Appendix A 
WHC-SD-WM-ER-548 Rev. 0

This page intentionally left blank.

GL-4 
WHC-SD-WM-ER-548 Rev. 0

APPENDIX A

OFF-NORMAL EVENTS

A-1 
WHC-SD-WM-ER-548 Rev. 0

This page intentionally left blank. 


\section{Off-Normal Events}

Off-normal events were developed from the list created in June 1995 (Awadalla 1995) at a brainstorming session on identifying events that would impact waste tank storage capacity and waste volume generation. Further meetings were held to review the developed list and add items that would also affect the capacity or waste generation.

Off-normal events considered include DST tank leak, pipe breaks in contaminated areas of process facilities. unusual waste characteristics in the SSTs, increased waste volume generation from the waste generators. discovery of buried hazardous waste near tank farms. industrial accident(s). seismic events, volcanic ash fall. significant flaws including corrosion. cracking found in DST(s). and fire in a tank farm facility.

\section{DST Tank Leak}

The first risk concern is a DST leak. No leaks have ever occurred at the Hanford Site, although at least one leak has been reported at the Savannah River Site (On 1 1995). The Savannah River tank that leaked had a tank pan similar in function to the double-shell containment liner used for Hanford DSTs. There are 28 DSTs. with a combined tank life of 400 years, which have never had a recorded tank leak. This has been due mainly to in-place heat treatment of the fabricated low carbon steel tanks at elevated temperatures in place (0ht 1995). In addition, a monitoring system in the annulus between the DSTs should detect a leak soon after it begins.

Based on the combined experience at Hanford and Savannah River a failure rate of one DST per 50 year period has been estimated. This number may be too low; therefore a range of variation from one tank failure in 100 years. to one tank failure in 30 years has been defined for this study. Guidelines being used for the sensitivity study require that either uniform or loguniform be assumed for all distributions within the selected ranges. A uniform distribution is used for the tank failure probability. Extending the range further would probably result in a loguniform sampling distribution to cover the lower frequencies adequately.

The DSTs vary in age from 15 to 25 years. This means that a significant portion of their design life has already been used. Extension of the assumed life of the tanks would require predictions for specific failure mechanisms over longer 11 fetimes.

Development of a corrosion failure model is being undertaken (Edgemon 1995) conjointly with the risk analysis. When parameters are available from the corrosion study the DST failure model will be revised to include those parameters.

As the tanks get older it would be expected that the failure rate would increase. An additional variable for this expectation has been put into the sensitivity study. The failure rate has been assumed to increase by a factor of 3 over the 20 year lifetime of the tank waste retrieval and disposal operation. 
The likely place for high corrosion to occur is at the vapor-liquid interface. If this occurs when the tank is full. simply lowering the interface may be enough to prevent leakage and the tank might continue in service. Since no basis has been worked out for requalifying a tank after it has leaked, it has been assumed that a leaky tank will remain out of service no matter at what level the leak occurred.

(VAR. VARIABLE NAME UNITS RANGE DISTRIB

NO.)

(1) DST Leak Occurrence $\quad / y r \quad 0.01$ to 0.03 UNIFORM Initial Rate

(2) DST Leak Occurrence yr/20yr 1.0 to 3.0 UNIFORM Rate Slope

Loca 1 Depth of

Occurrence - (tank is lost at any depth) FIXED

\section{Changing Seismic Requirements}

Seismic requirements may change at any time because of new data or increased conservatism.

\begin{tabular}{|c|c|c|c|c|}
\hline $\begin{array}{l}\text { (VAR. } \\
\text { NO.) }\end{array}$ & VARIABLE NAME & UNITS & RANGE & DISTRIB \\
\hline (3) & $\begin{array}{l}\text { Date of Seismic } \\
\text { Requirements Change }\end{array}$ & $\mathrm{CY}$ & 1996 to 2015 & UNIFORM \\
\hline (4) & Seismic Requirement & $\%$ & 0 to 10 & UNIFORM \\
\hline
\end{tabular}

\section{Extended Outage of Evaporator}

The 242-A Evaporator is the fourth evaporator to be constructed at Hanford. The facility was built in 1973 with operations starting in 1977. Normal throughput for the evaporator is $45 \mathrm{gpm}$ without ion exchange. Historically, the evaporator has been operational two to three months per year. An entire year of operations could easily process four to five million gals/yr. The facility was shut down due to environmental concerns and the B-534 modification was started to ensure the facility would be operational through the year 2000 (242-A Evaporator Facility Orientation Course No. 350540 [Jensen 1993]). The evaporator facility is in good shape after renovation. (i.e. "nominal" 10 year 1 ife extension has been completed). Life extension beyond 10 years could be justified if NDT results provide the basis (Thurkow 1995, Jensen 1995). Duration of an extended evaporator outage could be from six months to three years. The rate during which the evaporator can fail is one month to six months/yr of operations with a four quarter (year) downtime due to general failure of support equipment. Any waste scheduled to be concentrated during the period of failure or during the extended outage period will be rescheduled during the next year. It is assumed that the evaporator could process 10,000 $\mathrm{kgals} / \mathrm{yr}$ of waste, if necessary. 


\begin{tabular}{|c|c|c|c|c|}
\hline $\begin{array}{l}\text { (VAR. } \\
\text { NO.) }\end{array}$ & VARIABLE NAME & UNITS & RANGE & DISTRIB \\
\hline (5) & $\begin{array}{l}\text { Duration of Extended } \\
\text { Outage of Evaporator }\end{array}$ & $\mathrm{yr}$ & 0.5 to 3.0 & UNIFORM \\
\hline (6) & $\begin{array}{l}\text { Failure Rate of } \\
\text { Evaporator for CY 1996-1998 }\end{array}$ & $y r$ & 0.1 to 0.5 & UNIFORM \\
\hline (7) & $\begin{array}{l}\text { Failure Rate of } \\
\text { Evaporator for CY } 1998-2000\end{array}$ & $\mathrm{yr}$ & 0.1 to 0.5 & UNIFORM \\
\hline (8) & $\begin{array}{l}\text { Failure Rate of Evaporator } \\
\text { for } \mathrm{CY} 2000-2002\end{array}$ & $y r$ & 0.1 to 0.5 & UNIFORM \\
\hline (9) & $\begin{array}{l}\text { Failure Rate of Evaporator } \\
\text { for } \mathrm{CY} 2002-2004\end{array}$ & $y r$ & 0.1 to 0.5 & UNIFORM \\
\hline (10) & $\begin{array}{l}\text { Failure Rate of Evaporator } \\
\text { for CY 2004-2006 }\end{array}$ & $y r$ & 0.1 to 0.5 & UNIFORM \\
\hline (11) & $\begin{array}{l}\text { Failure Rate of Evaporator } \\
\text { for } \mathrm{CY} 2006-2008\end{array}$ & $\mathrm{yr}$ & 0.1 to 0.5 & UNIFORM \\
\hline $\begin{array}{l}\text { (VAR. } \\
\text { NO.) }\end{array}$ & VARIABLE NAME & UNITS & RANGE & DISTRIB \\
\hline (12) & $\begin{array}{l}\text { Failure Rate of Evaporator } \\
\text { for } \mathrm{CY} 2008-2010\end{array}$ & $\mathrm{yr}$ & 0.1 to 0.5 & UNIFORM \\
\hline (13) & $\begin{array}{l}\text { Failure Rate of Evaporator } \\
\text { for } \mathrm{CY} 2010-2012\end{array}$ & $y r$ & 0.1 to 0.5 & UNIFORM \\
\hline (14) & $\begin{array}{l}\text { Failure Rate of Evaporator } \\
\text { for CY 2012-2014 }\end{array}$ & $\mathrm{yr}$ & 0.1 to 0.5 & UNIFORM \\
\hline (15) & $\begin{array}{l}\text { Failure Rate of Evaporator } \\
\text { for } \mathrm{CY} 2014 \text { - }\end{array}$ & $\mathrm{yr}$ & 0.1 to 0.5 & UNIFORM \\
\hline
\end{tabular}

\section{Cross-Site Transfer System Failure}

Basis for failure is found in Coles (1995) (Figure 2-7). Failure of the crosssite transfer line would affect the removal of waste from 200 west SSTs and the SY tank farm. Figure 2-7 identifies the in-service failure as $1.6 \mathrm{E}$-1/year and the line completion at $8 \mathrm{E}-1 /$ year. The dates are educated guesses approximating delays that could occur from problems not anticipated.

\begin{tabular}{|c|c|c|c|c|}
\hline $\begin{array}{l}\text { (VAR. } \\
\text { NO. }\end{array}$ & VARIABLE NAME & UNITS & RANGE & DISTRIB \\
\hline$(16)$ & $\begin{array}{l}\text { old Cross-Site Line } \\
\text { Fajlure Rate }\end{array}$ & /yr & 1. $0 \mathrm{E}-2$ to $1.0 \mathrm{E}-1$ & LOGUNIFORM \\
\hline (17) & $\begin{array}{l}\text { New Cross-Site Line } \\
\text { Failure Rate }\end{array}$ & lyr & 1.0E-4 to $1.0 \mathrm{E}-2$ & LOGUNIFORM \\
\hline (18) & $\begin{array}{l}\text { Date of Initiation of } \\
\text { New Transfer Line }\end{array}$ & CY & 1998 to 2005 & UNIFORM \\
\hline
\end{tabular}

Variables 19-27 are reserved for privatization effects and consolidation effects that were not included in this study. 


\section{SST Leakage Unti1 New Cross Site Transfer System Is Available}

Leakage in a 200W SST could impact the schedule if additional waste needs to be removed from the leaking SST. This could easily create a storage availability problem. Table 2-4 (Coles 1995) identifies 0.7 tanks may leak over the 3 yr period until the cross site line is complete.

$\begin{array}{llll}\text { (VAR. VARIABLE NAME } & \text { UNITS } & \text { RANGE } & \text { DISTRIB } \\ \text { NO.) } & & & \\ \text { (28) Number of SSTs Leaked } & y r & 1 / 150 \text { to } 1 / 50 & \text { UNIFORM } \\ \text { (18) Date of Initiation of } & \mathrm{CY} & 1998 \text { to } 2005 & \text { UNIFORM }\end{array}$

\section{Waste Volume Reduction Factors}

Variations from the nominal design value of the waste volume reduction factor of 0.50 have been assumed as engineering judgment.
(VAR. VARIABLE NAME
UNITS RANGE
DISTRIB
NO.)
(29) Complexed Waste Volume
0.25 to .55
UNIFORM
Reduction Factor
(30) This variable is a spare.
Uncomplexed waste volume
reduction factor
0.8
FIXED

\section{Pipe Breaks in Contaminated Facility Areas}

Pipe breaks and subsequent flooding from a raw water line in a contaminated facility would create additional waste volume requiring remediation. A documented failure produced 56,000 gallons of additional waste (Coles 1995). The main impact of a pipe break is the creation of additional waste. A range of 0 to 1.000 .000 gallons was chosen to represent the potential volume. This is a judgment of what could happen, should a significant leakage in a facility occur. With reduced manpower for monitoring. a leak could go undetected for a significant period of time before being discovered and mitigated. Estimate is based on judgment assuming one facility, and that operations would stop if a major break in a system occurred.

\begin{tabular}{|c|c|c|c|c|}
\hline $\begin{array}{l}\text { (VAR. } \\
\text { NO.) }\end{array}$ & VARIABLE NAME & UNITS & RANGE & DISTRIB \\
\hline (31) & $\begin{array}{l}\text { Volume per Pipe Break } \\
\text { Leak }\end{array}$ & gal & 0 to $1 . E+6$ & UNIFORM \\
\hline (32) & $\begin{array}{l}\text { Frequency of Leak } \\
\text { Occurrence }\end{array}$ & /yr & $1.0 \mathrm{E}-4$ to $1.0 \mathrm{E}-1$ & LOGUNIFORM \\
\hline \multirow[t]{2}{*}{ (33) } & $\begin{array}{l}\text { Date Facility Operation } \\
\text { Ceased due to Break }\end{array}$ & CY & 1996 to 2016 & UNIFORM \\
\hline & $\begin{array}{l}\text { Number of } \\
\text { Facilities that can Brea }\end{array}$ & & 1 & FIXED \\
\hline
\end{tabular}


Regulatory Changes of Impact Waste Volume

Increased sludge washing, additional dilution requirements, or other potential requirements could increase volume. The regulatory change could occur at any time during the program.

(VAR. VARIABLE NAME UNITS RANGE DISTRIB

NO.)
(34) Volume Increase Due gal 0 to $1.0 E+6$ UNIFORM

to Regulatory Change

Date Regulatory CY 1996 to 2016 UNIFORM

Change Affects Volume

Number of Volume 11 FIXED

Affecting Regulatory Changes

Assume only one change causing impact on volume of waste.

Requirements to Dilute Safety Tanks, Such as Tank 101-SY

Dilution of 1:1 is discussed in the OWVP (Strode and Koreski 1995) as part of the Ecology run. Should other issues arise, further dilution could be required.

Dilution requirements could occur at any time in the period under consideration.

(VAR. VARIABLE NAME UNITS RANGE DISTRIB

NO.) $\quad 1.0$ to 3.0

(36) Di 7ution Factor to 1.0 to 3.0 UNIFORM

(37) Date Dilution of CY 1996 to 2016 UNIFORM

Safety Tanks Required

Number of Tanks 1

Diluted for Safety Reasons

1 FIXED

\section{Accomodate IMUST Waste Volume Dilution}

Contents of IMUSTs may need to be diluted to meet different requirements of storage in feed tanks.

\begin{tabular}{|c|c|c|c|c|}
\hline $\begin{array}{l}\text { (VAR. } \\
\text { NO.) }\end{array}$ & VARIABLE NAME & UNITS & RANGE & DISTRIB \\
\hline (38) & $\begin{array}{l}\text { Dilution Factor of } \\
\text { IMUST Tanks }\end{array}$ & & 5 to 10 & UNIFORM \\
\hline (39) & $\begin{array}{l}\text { Date Dilution of } \\
\text { IMUST Tanks Required }\end{array}$ & CY & 1996 to 2016 & UNIFORM \\
\hline$(40)$ & $\begin{array}{l}\text { Volume of IMUST } \\
\text { Waste to Dilute }\end{array}$ & ga 1 & $1.0 \mathrm{E}+5$ to $1.0 \mathrm{E}+6$ & UNIFORM \\
\hline
\end{tabular}




\section{Characterization Discovers Unusual SST Waste Characteristics}

The potential for finding waste chemistries and physical characteristics that have not been identified or evaluated is considered here. This is an engineering judgment of the effect these characteristics would have. Variable 43 assumes characterization is completed by 2001.

\begin{tabular}{|c|c|c|c|}
\hline $\begin{array}{l}\text { (VAR. } \\
\text { NO.) }\end{array}$ & VARIABLE NAME & RANGE & DISTRIB \\
\hline (41) & $\begin{array}{l}\text { Number of Tanks } \\
\text { With New Unusual Characteristics }\end{array}$ & 1 to 2 & UNIFORM \\
\hline (42) & $\begin{array}{l}\text { Increased Volume to } \\
\text { Treatment From Unusual Waste }\end{array}$ & 1 to 2 & UNIFORM \\
\hline (43) & $\begin{array}{l}\text { Beginning Date for } \quad C Y \\
\text { Treatment of Unusual Waste }\end{array}$ & 1996 to 2001 & UNIFORM \\
\hline
\end{tabular}

Increase Waste Generators Output

Unexpected increases in volumes of waste from generators can occur at any time during the expected period of operation of those generators. Variable 49 assumes that the waste found is not radioactive or mixed waste.

\begin{tabular}{|c|c|c|c|c|}
\hline $\begin{array}{l}\text { (VAR. } \\
\text { NO.) }\end{array}$ & VARIABLE NAME & UNITS & RANGE & DISTRIB \\
\hline$(44)$ & $\begin{array}{l}\text { K-Basin waste volume } \\
\text { Increase Factor }\end{array}$ & & 1 to 2 & UNIFORM \\
\hline$(45)$ & $\begin{array}{l}\text { Beginning Date of } \\
\text { Added K-Basin Waste }\end{array}$ & $\mathrm{CY}$ & 1996 to 2005 & UNIFORM \\
\hline (46) & $\begin{array}{l}\text { B-Plant Waste Volume } \\
\text { Increase Factor }\end{array}$ & & 1 to 2 & UNIFORM \\
\hline$(47)$ & $\begin{array}{l}\text { Beginning Date of } \\
\text { Added B-Plant Waste }\end{array}$ & $C Y$ & 1996 to 2003 & UNIFORM \\
\hline (48) & $\begin{array}{l}\text { Purex Waste Volume } \\
\text { Increase Factor }\end{array}$ & & 1 to 2 & UNIFORM \\
\hline \multirow[t]{3}{*}{ (49) } & $\begin{array}{l}\text { Beginning Date of } \\
\text { Added Purex Waste }\end{array}$ & $\mathrm{CY}$ & 1996 to 2007 & UNIFORM \\
\hline & $\begin{array}{l}\text { Increases in other } \\
\text { Waste Sources }\end{array}$ & & 0 & FIXED \\
\hline & $\begin{array}{l}\text { Additional Liquid } \\
\text { Waste Volume Due to } 0\end{array}$ & & 0 & FIXED \\
\hline
\end{tabular}




\section{Discovery of 01d Hazardous Waste Near Tank Farms}

Waste that is hazardous and unstable could be found buried near tank farms. creating a potential threat to tanks or tank farm operations until it is removed or stabilized. Such waste could include cleaning solvents, petroleum products, or military ammunition. The newly discovered waste is assumed not to add to the volume of waste in the tanks. Variable 50 estimates that it could be found at any time.

(VAR. VARIABLE NAME UNITS RANGE DISTRIB

N0.) Date of Discovery CY 1996 to 2016 UNIFORM

(51) Schedule Delay Due yr 1 to 2 UNIFORM

to Discovery of 01d Waste

Additional Liquid 0 FIXED

Waste volume due to old Waste

Accelerate Saltwe11 Pumping

Acceleration is due to increase in the number of SST failures. This speeds up the remediation of SSTs to prevent additional releases.

\begin{tabular}{|c|c|c|c|c|}
\hline \multirow{3}{*}{$\begin{array}{l}\text { (VAR. } \\
\text { NO.) } \\
(52)\end{array}$} & VARIABLE NAME & UNITS & RANGE & DISTRIB \\
\hline & $\begin{array}{l}\text { Increased Rate of } \\
\text { Saltwell Pumping }\end{array}$ & Factor & 1 to 2 & UNIFORM \\
\hline & $\begin{array}{l}\text { Change in Total } \\
\text { Volume of Salt Waste }\end{array}$ & gal & 0 & FIXED \\
\hline
\end{tabular}

Failure of Local Transfers

Assume failure of intrafarm transfer piping.

(VAR, VARIABLE NAME UNITS RANGE DISTRIB

(50.) This variable was temporarily omitted from the study.

Frequency of Local /yr 0.05 to $0.20 \quad$ LOGUNIFORM

Transfer Failure

(54) This variable was temporarily omitted from the study.
Thisume frequency, since there have been such failures

Schedule Delay Per yr 0.5 to $1.0 \quad$ UNIFORM

Fai]ure

(A fäjlure of a local transfer system within a farm could prevent transfers from occurring.) 
Retrieval/Disposal Schedule S1ip

This is an assumption that the schedule could slip for some reason.

(VAR. VARIABLE NAME UNITS RANGE DISTRIB

NO.)

(55) Date of Delay of CY 1996 to 2016 UNIFORM

(56) Amount of Delay yr 1.0 to 2.0 UNIFORM
Un 1.0 Disposal Due to Retrieval/Disposal Slip

TPA Milestone Not Met or Delayed delayed

This is an assumption to evaluate the effect of a TPA milestone not met or (VAR. VARIABLE NAME UNITS RANGE DISTRIB

(50.) This variable was temporarily omitted from the study.

Schedule Delay Due yr 1.0 to $5.0 \quad$ UNIFORM to TPA Milestone Slip

Contractor Change

Contractor change could introduce delays due to personnel and management structure changes with a new contractor. It is assumed that the effect would be negative.

$\begin{array}{cllll}\begin{array}{c}\text { (VAR. } \\ \text { NO.) }\end{array} & \text { VARIABLE NAME } & \text { UNITS } & \text { RANGE } & \text { DISTRIB } \\ \text { (58) } & \begin{array}{l}\text { Date of Contractor } \\ \text { Changeover }\end{array} & \mathrm{CY} & 1996 \text { to } 2016 & \text { UNIFORM } \\ \begin{array}{l}\text { (59) } \\ \begin{array}{l}\text { Schedule Delay Due } \\ \text { to Contractor Change }\end{array}\end{array} & \text { yr } & 0.5 \text { to } 2.0 & \text { UNIFORM }\end{array}$

Assumes delay while organizational changes and redefinition of priorities and funding. 


\section{Industrial Safety Issues Stop Tank Farm Activities}

Industrial safety issues, such as accidents, could result in a shutdown of tank farm activities to investigate and solve industrial safety issues. This has happened in the last three years, where incidents resulted in the shutdown of TWRS activities until the issues were resolved. It is possible that this could occur again. therefore significantly impacting the schedule.

\begin{tabular}{|c|c|c|c|c|}
\hline $\begin{array}{l}\text { (VAR. } \\
\text { NO.) }\end{array}$ & VARIABLE NAME & UNITS & RANGE & DISTRIB \\
\hline$(60)$ & $\begin{array}{l}\text { Date of Stoppage Due } \\
\text { to Industrial Safety }\end{array}$ & CY & 1996 to 2016 & UNIFORM \\
\hline (61) & $\begin{array}{l}\text { Schedule Delay Due to } \\
\text { Industrial Safety Stoppa }\end{array}$ & & 0.5 to 1.0 & UNIFORM \\
\hline (62) & $\begin{array}{l}\text { Date of Replacement of } \\
\text { Government Customer }\end{array}$ & CY & 1996 to 2016 & UNIFORM \\
\hline (63) & $\begin{array}{l}\text { Schedule Delay yr } \\
\text { due to Sponsor Replaceme }\end{array}$ & & 1.0 to 2.0 & UNIFORM \\
\hline
\end{tabular}

Assumes delay while organizational changes and redefinition of priorities and funding.

\section{System Engineering Structure Inconsistent with Path Forward}

This effect would be due to a defect in the planning activity.

\begin{tabular}{|c|c|c|c|c|}
\hline $\begin{array}{l}\text { (VAR. } \\
\text { NO.) }\end{array}$ & VARIABLE NAME & UNITS & RANGE & DISTRIB \\
\hline (64) & $\begin{array}{l}\text { Date of Stoppage Due } \\
\text { to Systen Engineering }\end{array}$ & $\begin{array}{c}\mathrm{CY} \\
\text { Defect }\end{array}$ & 1996 to 2016 & UNIFORM \\
\hline (65) & $\begin{array}{l}\text { Schedule Delay Due } \\
\text { to System Engineering }\end{array}$ & $\begin{array}{c}\text { yr } \\
\text { Defect }\end{array}$ & 0.5 to 1.0 & UNIFORM \\
\hline
\end{tabular}

New Tanks to be Added to Watch List

The addition of tanks to the watchlist is an estimate assuming one to two tanks will be added over the next five years during the completion of characterization. The effect is identical to a previous risk item.

(VAR. VARIABLE NAME UNITS RANGE DISTRIB

NO.)

$\begin{array}{lll}\text { (41) Number of Tanks with } & 1 \text { to } 2 & \text { UNIFORM }\end{array}$

(42) Increased volume to 1 to 2 UNIFORM

(43) Beginning Date for CY 1996 to 2001 UNIFORM 


\section{Emerging Scenarios from Outside Sources}

This is an assumption that outside labs or government research could identify scenarios that could affect the safety of the tanks. These scenarios would then require an evaluation, resulting in a schedule delay.

\section{(VAR, VARIABLE NAME UNITS RANGE DISTRIB}

(60.) This variable was temporarily omitted from the study.

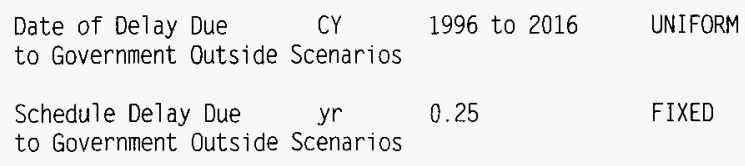

This has occurred in the past and it is assumed that it could occur again.

\section{Significant Seismic Event}

A "significant" seismic event is one that approaches or exceeds design or operating criteria. This addresses an assumed impact on schedule resulting from analyses that may be required to ensure system integrity and continued remediation activities. This is an assumption.

\begin{tabular}{|c|c|c|c|c|}
\hline (VAR. & VARIABLE NAME & UNITS & RANGE & DISTRIB \\
\hline (67) & $\begin{array}{l}\text { Frequency of } \\
\text { Significant Seismic Even }\end{array}$ & /yr & 1.0E-3 to $1.0 \mathrm{E}-4$ & LOGUNIFORM \\
\hline (68) & $\begin{array}{l}\text { Schedule Delay Due to } \\
\text { to Significant Seismic }\end{array}$ & $\begin{array}{l}\text { yr } \\
\text { Event }\end{array}$ & 0.5 to 3.0 & UNIFORM \\
\hline
\end{tabular}

Required studies may be required to assess the conditions of the tanks and systems before remediation activities continue.

\section{Significant Ashfall}

Significant ashfall could interrupt tank farm activities by rendering farm equipment inoperable, thus delaying remediation activities until equipment is restored. Potential sources are the Cascade volcanos to the west. The last ashfall was in 1980 .

Tallman (1996) has documented Cascade Range Volcanic ash hazards in terms of annual probability of exceedence of depth of ashfall. Probabilities range from $10^{-3}$ to $10^{-7}$ per year for ashfalls from 0 to $100 \mathrm{~cm}$. These values have been compared with loading limits for canister storage buildings. Extension of the analysis to underground waste storage tanks is needed. 
WHC-SD-WM-ER-548 Rev. 0

\begin{tabular}{|c|c|c|c|c|}
\hline $\begin{array}{l}\text { (VAR. } \\
\text { NO.) }\end{array}$ & VARIABLE NAME & UNITS & RANGE & DISTRIB \\
\hline (69) & $\begin{array}{l}\text { Frequency of } \\
\text { Significant Ashfall }\end{array}$ & $/ y r$ & 1.0E-2 to $1.0 \mathrm{E}-3$ & LOGUNIFORM \\
\hline (ח) & $\begin{array}{l}\text { Schedule Delay Due } \\
\text { to Significant Ashfall }\end{array}$ & $y r$ & 0.5 to 3.0 & UNIFORM \\
\hline
\end{tabular}

Studies may be required to assess the conditions of the tanks and systems before remediation activities continue

Violating Segregation Rules Gives New Path Forward

This could provide a different composition of wastes that could require a change in processing plans.

$\begin{array}{cllll}\begin{array}{c}\text { (VAR. } \\ \text { NO.) }\end{array} & \text { VARIABLE NAME } & \text { UNITS } & \text { RANGE } & \text { DISTRIB } \\ \text { (71) } & \begin{array}{l}\text { Date of Segregation } \\ \text { Rule Violation }\end{array} & \text { CY } & 1996 \text { to } 2016 & \text { UNIFORM } \\ \text { (72) } & \begin{array}{l}\text { Schedule Delay Due } \\ \text { to New Path Forward }\end{array} & \text { yr } & 0.25 \text { to } 5.0 & \text { UNIFORM } \\ & & & \end{array}$

Potential Primary NDE Indications in SSTs

Inspection of the DSTs is scheduled to begin in FY 1996 (Pflueger 1994). The NDE will consist of ultrasonic examination to evaluate the wall thickness and identify any flaws in the primary tank wall. The inspections will be performed on a sample of the tank wall and a sample of tanks. Six tanks are scheduled to be examined. If flaws are identified or wall thinning is found that exceeds acceptance criteria (Pfleuger 1994), an evaluation for continued service of the tank will be performed.

$\begin{array}{llccc}\text { (VAR. } & \text { VARIABLE NAME } & \text { UNITS } & \text { RANGE } & \text { DISTRIB } \\ \text { NO.) } & \text { Date of Tank } & \text { CY } & 1996 \text { to } 2016 & \text { UNIFORM } \\ \text { (73) } & \text { NDE Effects } & & & \\ & \begin{array}{l}\text { Indications of flaws could be found at any time during this period. } \\ \text { (74) }\end{array} & \begin{array}{l}\text { Tank volumes Out of } \\ \text { Service due to NDE }\end{array} & \text { tanks } 0.5 \text { to } 1.5 & \text { UNIFORM }\end{array}$

Flaws could be at an elevation that could take a tank out of service or require lowering the waste level to reduce the load or stop a leak. The flaw could be generic, affecting more than one tank

Fire in Tank Farm Facilities

A fire in the HVAC system or electrical systems could cause a suspension of activities in a farm until the damage is repaired and the incident is investigated. Depending on extent or location of damage. studies may be required to assess the conditions of the tanks and systems before mitigating activities continue. 
WHC-SD-WM-ER-548 Rev. 0

$\begin{array}{cllll}\text { (VAR. } & \text { VARIABLE NAME } & \text { UNITS } & \text { RANGE } & \text { DISTRIB } \\ \text { NO.) } & & & & \\ \text { (75) } & \text { Date of Fire } & \mathrm{CY} & 1996 \text { to } 2016 & \text { UNIFORM } \\ \text { (76) } & \text { Schedule Delay Due } & \mathrm{yr} & 0.3 \text { to } 1.5 & \text { UNIFORM }\end{array}$

\section{Waste Model Variables}

The distribution ranges of the waste model variables are those determined by the ARES Corporation (Thurkow 1995) except for the porosity. The porosity was changed based upon engineering judgment. The type of distribution was changed from a triangular distribution to uniform.

\begin{tabular}{|c|c|c|c|c|}
\hline (VAR. & VARIABLE NAME & UNITS & RANGE & DISTRIB \\
\hline \multirow[t]{2}{*}{ (77) } & $\begin{array}{l}\text { Volume of Tank C-106 } \\
\text { Solids }\end{array}$ & kgal & 700 to 1600 & UNIFORM \\
\hline & $\begin{array}{l}\text { Initial Complexed } \\
\text { Waste Storage Volume }\end{array}$ & kgal & 4926 & FIXED \\
\hline (78) & $\begin{array}{l}\text { Volume of T-Plant } \\
\text { Waste }\end{array}$ & kgal & 50 to 200 & UNIFORM \\
\hline$(79)$ & $\begin{array}{l}\text { Volume of } \mathrm{N} \text {-Basin } \\
\text { Waste }\end{array}$ & kga $\rceil$ & 0 to 2700 & UNIFORM \\
\hline$(80)$ & $\begin{array}{l}\text { Volume of Tank } \\
\text { AZ-101 Waste }\end{array}$ & kgal & 800 to 4000 & UNIFORM \\
\hline (81) & $\begin{array}{l}\text { Complexed Waste } \\
\text { Evaporate Fraction }\end{array}$ & & 0 to 0.111 & UNIFORM \\
\hline (82) & This variable has be & & & \\
\hline
\end{tabular}

$$
\begin{aligned}
& \text { Fraction Complexed } \quad 0.150 \text { to } 0.200 \text { UNIFORM } \\
& \text { SST Solids } \\
& \text { (83) This variable has been temporarily deleted from the study. }
\end{aligned}
$$

Fraction Complex 0.55 to 0.65 UNIFORM Waste After CY2000 in NonComplex Waste

(84) Minimum Fraction of 0.75 to $0.95 \quad$ UNIFORM

(85) Minimum Fraction of 0.75 to 0.95 UNIFORM Waste to Pretreatment Facility
(86) Minimum Fraction of 0.75 to $0.95 \quad$ UNIFORM waste to Vitrification Facility

(87) Volume of Cesium to kgal 50 to 150 UNIFORM to Pretreatment Facility

(88) Vitrification Rate

$\begin{array}{lll}\% \text { of } & 50 \text { to } 130 & \text { UNIFORM } \\ \text { nominal } & & \\ \% \text { of } & 50 \text { to } 150 & \text { UNIFORM } \\ \text { nomina } & & \end{array}$


WHC-SD-WM-ER-548 Rev. 0

\begin{tabular}{|c|c|c|c|c|}
\hline $\begin{array}{l}\text { (VAR. } \\
\text { NO.) }\end{array}$ & VARIABLE NAME & UNITS & RANGE & DISTRIB \\
\hline$(90)$ & West Saltwell & $\%$ of & 35 to 61 & UNIFORM \\
\hline & Liquid (Porosity) & nominal & & \\
\hline \multirow[t]{2}{*}{ (91) } & \multicolumn{4}{|c|}{ This variable was temporarily deleted from the study. } \\
\hline & $\begin{array}{l}\text { East Saltwel1 } \\
\text { Liquid (Porosity) }\end{array}$ & $\%$ & 35 to 61 & UNIFORM \\
\hline (92) & East SST Solids & kgal & 80 to 120 & UNIFORM \\
\hline (93) & West Area Tank 101SY & kgal & 50 to 150 & UNIFORM \\
\hline (94) & Wast Area Tank 103SY & kgal & 50 to 150 & UNIFORM \\
\hline (95) & 5B-Plant & kgal & 25 to 150 & UNIFORM \\
\hline (96) & East Raw Water Usage & kgal & 50 to 150 & UNIFORM \\
\hline (97) & $\begin{array}{l}\text { East Evaporator } \\
\text { Flush Water }\end{array}$ & kgal & 50 to 150 & UNIFORM \\
\hline (98) & East Flush Water & kgal & 50 to 150 & UNIFORM \\
\hline (99) & West Area Tank 1025Y & kgal & 50 to 150 & UNIFORM \\
\hline$(100)$ & Tank 105AW Solids & kgal & 50 to 150 & UNIFORM \\
\hline (101) & Dilute DST Waste & kgal & 50 to 150 & UNIFORM \\
\hline (102) & $\begin{array}{l}\text { Sludge to } \\
\text { Vitrification }\end{array}$ & kgal & 50 to 150 & UNIFORM \\
\hline
\end{tabular}

See Table C-2 for nominal values. 


\section{REFERENCES}

Awadalla, N.G., 1995. Risk Management Workshop Paper, paper for brainstorming session held June 28, 1995. Westinghouse Hanford Company, Richland, Washington.

Coles. C., 1995. “Operational Risk Assessment of Multi-Waste Tank Facility Path Forward", WHC-SD-W236A-ES-014. Draft. Westinghouse Hanford Company. Richland. Washington.

Edgemon. G. L. and R. P. Anantatmula, 1995. Hanford Waste Tank Degradation Mechanisms. WHC-SD-WM-ER-414, Rev. 0. Westinghouse Hanford Company. Richland, Washington.

Jensen. C. E.. 1995. Acceptance Criteria for Non-Destructive Examination of DoubleShell Tanks, WHC-SD-WM-AP-036, Westinghouse Hanford Company. Richland. Washington.

Jensen. C. E., 1993, Data Package for 242-A Evaporator/Crystallizer Tank System Integrity Assessment, WHC-SD-WM-DP-019. Westinghouse Hanford Company. Richland, Washington.

Oh1, P.C.. 1995. "The 242-A Evaporator/Crystallizer Tank System Integrity Assessment Report", WHC-SD-WM-ER-124. Westinghouse Hanford Company, Richland, Washington.

Pflueger, D.C., 1994, "Double-She17 Tank Ultrasonic Inspection Plan", WHC-SD-WM-AP019. Westinghouse Hanford Company. Richland. Washington.

Strode, J.N. and G.M. Koreski. 1995, Operational Waste Volume Projections, WHC-SO-WMER-029, Revision 21. Westinghouse Hanford Company, Richland, Washington.

Tallman, A.N., 1996. "Canister Storage Building Natural Phenomena Design Loads", WHCSD-SNF-DB-009, Rev. 0. Westinghouse Hanford Company, Richland. Washington.

Thurkow, T.J., 1995. "A Risk Management Approach to Double-Shel1 Tank Waste Volume Versus Storage Capacity". WHC-SD-WM-ER-527, Revision 0. Westinghouse Hanford Company, Richland, Washington. 
WHC-SD-WM-ER-548 Rev. 0

APPENDIX B

FALL-BACK POSITIONS

B-1 
WHC-SD-WM-ER-548 Rev. 0

This page intentionally left blank. 


\section{Fall-Back Positions}

The fall-back positions considered include delaying operations during critical capacity periods, requiring the generators to process excess waste over the predicted quantities, suspending saltwell pumping. using SSTs as temporary waste storage, activating the grout program, using the grout vaults for temporary waste storage, requiring waste generators to reduce the volume of waste generated. building new tank5, adding waste to IMUSTs for temporary storage, and using chemical adjustment methods to reduce incoming volume. These were the fall-back positions input into the model for evaluation.

Fall-back positions were developed from the first list developed in June 1995 (Awadalla 1995). Additional fall-back positions were added to the above list. These fall-back positions were selected to help meet the capacity requirements should current waste management strategies fail. Several positions are suggested that have not been technically evaluated. The build new tanks option was selected as a fall-back because the origin of the MWTF phase-out is to avoid or delay the need for new tanks.

\section{Fall-Back Position: Delay Operations}

The concept of delaying is usually included as a primary variable in each fallback position. Acceptance of waste from generators could be delayed to keep the volume of processed waste requiring storage to a minimum during the periods of vulnerability. Acceptance of waste from generators and SSTs is delayed until it can be processed. The period of delay is based on events that could dramatically impact the storage capability. Failure of one or two DSTs, additional waste requiring processing, and programmatic changes, all could cause significant delays in processing.

\section{(VAR. VARIABLE NAME UNITS RANGE DISTRIB}

NO.)
(103) Delay of Operations yr 0.25 to 10 UNIFORM

\section{Fall-Back Position: Start Evaporator(OELETED)}

When idle, the evaporator could be started to process excess volume.

\section{(VAR. VARIABLE NAME UNITS RANGE DISTRIB}

(104) This variable has been temporarily set at zero.

$\begin{array}{lll}\text { Start Evaporator } & 0 \text { or } 1 & \text { DISCRETE }\end{array}$ 
Fal1-Back Position: Facility to Deal with Excess Volume

Additional volume could be processed by the facility that generates the waste. This could involve building a processing facility at the generator.

(VAR. VARIABLE NAME UNITS RANGE, DISTRIB

Decide to Use or Build Another Facility

Delay Time to Use $\quad 3.0$ to 6.0

0 or 1

DISCRETE

\section{Fall-Back Position: Suspend Saltwell Pumping}

This position would delay addition of waste to DSTS. This is a possibility to carry through the critical storage periods. Variables 110 through 115 are possibilities to help with failure of cross-site transfers or intra-farm transfer systems. Variable 113 has been temporarily set to 0 because of the similarity in failures of the two transfer systems.

\begin{tabular}{|c|c|c|c|c|}
\hline $\begin{array}{l}\text { (VAR. } \\
\text { NO.) }\end{array}$ & VARIABLE NAME & UNITS & RANGE & DISTRIB \\
\hline (107) & $\begin{array}{l}\text { Suspend Saltwell } \\
\text { Pumping }\end{array}$ & & 0 or 1 & DISCRETE \\
\hline (108) & $\begin{array}{l}\text { Date Sal twel1 } \\
\text { Pumping Suspended }\end{array}$ & & 1996 to 2015 & UNIFORM \\
\hline (109) & $\begin{array}{l}\text { Duration of Saltwell } \\
\text { Pumping Suspension }\end{array}$ & $y r$ & 1 to 20 & UNIFORM \\
\hline (110) & $\begin{array}{l}\text { Implement Cross Site } \\
\text { Aboveground Transfer }\end{array}$ & & 0 or 1 & DISCRETE \\
\hline (111) & $\begin{array}{l}\text { Above Ground Cross } \\
\text { Site Transfer Rate/ } \\
\text { Normal Rate/Arbitrary } \\
\text { Rate }\end{array}$ & $\mathrm{kgal} / \mathrm{yr}$ & 0.1 to 0.5 & UNIFORM \\
\hline (112) & $\begin{array}{l}\text { Duration of } \\
\text { Aboveground Cross } \\
\text { Site Transfer }\end{array}$ & yr & 0.5 to 5.0 & UNIFORM \\
\hline \multirow[t]{2}{*}{ (113) } & This variable has been & temporari & 1y set at zero. & \\
\hline & $\begin{array}{l}\text { Implement Loca } 1 \\
\text { Aboveground Transfer }\end{array}$ & & 0 or 1 & DISCRETE \\
\hline (114) & $\begin{array}{l}\text { Aboveground Local } \\
\text { Transfer Rate/Normal } \\
\text { Rate }\end{array}$ & $\mathrm{kgal} / \mathrm{yr}$ & 0.1 to 0.5 & UNIFORM \\
\hline (115) & $\begin{array}{l}\text { Duration of } \\
\text { Aboveground Local } \\
\text { Transfer }\end{array}$ & $y r$ & 0.25 to 1.0 & UNIFORM \\
\hline
\end{tabular}




\section{Fa11-Back Position: Use SSTs as Temporary Storage}

Some of the SSTs could be used to store waste temporarily, adding volume during periods of DST volume shortages. Variables 116 and 117 assume DST storage for grout feed is not available and the waste is therefore stored in SSTs. Use of the SSTS would require legal and political revision to the TPA and approval from the stakeholders which could be a long process. An arbitrary volume is represented since it would be dependent on how many SSTs are needed.

\begin{tabular}{|c|c|c|c|c|}
\hline $\begin{array}{l}\text { (VAR. } \\
\text { NO.) }\end{array}$ & VARIABLE NAME & UNITS & RANGE & DISTRIB \\
\hline (116) & $\begin{array}{l}\text { Decide to Use SSTS } \\
\text { as Temporary Storage }\end{array}$ & & 0 or 1 & DISCRETE \\
\hline (117) & $\begin{array}{l}\text { Date of Decision to } \\
\text { Use SSTS Temporary } \\
\text { Storage }\end{array}$ & $\mathrm{CY}$ & 1996 to 2015 & UNIFORM \\
\hline (118) & $\begin{array}{l}\text { Delay for Public } \\
\text { Approval of SST as } \\
\text { Temporary }\end{array}$ & $y r$ & 1 to 5 & UNIFORM \\
\hline (119) & $\begin{array}{l}\text { Volume of SST } \\
\text { Temporary Storage }\end{array}$ & Tanks & 0.1 to $5.0 \mathrm{mga} 7$ & UNIFORM \\
\hline
\end{tabular}

\section{Fall-Back Position: Activate Grout Program}

The grout program could be used to reduce capacity requirements. Disposing of LAW in grout form was an alternative considered in the recent TWRS Environmental Impact Statement work. The facility would need to be put back into service, since it was abandoned. An arbitrary volume was represented that may be required to feed the grout system.

\begin{tabular}{|c|c|c|c|c|}
\hline $\begin{array}{l}\text { (VAR. } \\
\text { NO.) }\end{array}$ & VARIABLE NAME & UNITS & RANGE & DISTRIB \\
\hline (120) & $\begin{array}{l}\text { Decide to Activate } \\
\text { Grout Program }\end{array}$ & & 0 or 1 & DISCRETE \\
\hline (121) & $\begin{array}{l}\text { Date of Decision } \\
\text { to Activiate Program }\end{array}$ & & 1996 to 2015 & UNIFORM \\
\hline (122) & $\begin{array}{l}\text { Delay for Public } \\
\text { Approval of Grout } \\
\text { Program }\end{array}$ & yr & 1 to 3 & UNIFORM \\
\hline (123) & $\begin{array}{l}\text { Volume of SST } \\
\text { Temporary Storage }\end{array}$ & Tanks & 0.1 to $5.0 \mathrm{mgal}$ & UNIFORM \\
\hline
\end{tabular}


Fa11-Back Position: Store Liquids in Existing Grout Vaults

The existing grout vaults could be used as temporary storage until the need for additional storage space has passed. Public approval may require extensive public meetings and hearings. An estimate of the vault volume was available.

\begin{tabular}{|c|c|c|c|c|}
\hline $\begin{array}{l}\text { (VAR. } \\
\text { NO.) }\end{array}$ & VARIABLE NAME & UNITS & RANGE & DISTRIB \\
\hline (124) & $\begin{array}{l}\text { Decide to Store } \\
\text { Liquids in Existing } \\
\text { Grout Vaults }\end{array}$ & & 0 or 1 & DISCRETE \\
\hline (125) & $\begin{array}{l}\text { Date of Decision } \\
\text { to Store Liquids in } \\
\text { Grout Vaults }\end{array}$ & & 1996 to 2015 & UNIFORM \\
\hline$(126)$ & $\begin{array}{l}\text { Delay for Public } \\
\text { Approval of Grout } \\
\text { Vault Liquids }\end{array}$ & $y r$ & 1 to 3 & UNIFORM \\
\hline (127) & $\begin{array}{l}\text { Volume of Temporary } \\
\text { Storage Grout Vaults }\end{array}$ & tanks & 0.1 to $5.0 \mathrm{mgal}$ & UNIFORM \\
\hline
\end{tabular}

\section{Eall-Back Position: Force Generators to Reduce volume}

The generators could be forced to reduce the volume of the waste during critical capacity periods. The generators could "slow" the rate at which waste is produced. Variables 128-130 are an estimate of how long it could take to "slow" the transfer of waste from the generators. Variable 131 is an arbitrary reduction of waste generation to evaluate the effect of this action.

\begin{tabular}{|c|c|c|c|c|}
\hline $\begin{array}{l}\text { (VAR. } \\
\text { NO.) }\end{array}$ & VARIABLE NAME & UNITS & RANGE & DISTRIB \\
\hline (128) & $\begin{array}{l}\text { Decide Generators } \\
\text { Must Reduce Volume }\end{array}$ & & 0 or 1 & DISCRETE \\
\hline (129) & $\begin{array}{l}\text { Date of Decision } \\
\text { Generators Must } \\
\text { Reduce Volume }\end{array}$ & & 1996 to 2015 & UNIFORM \\
\hline (130) & $\begin{array}{l}\text { Time to Implement } \\
\text { Generator Volume } \\
\text { Reduction }\end{array}$ & $\mathrm{yr}$ & 0.1 to 1.0 & UNIFORM \\
\hline (131) & $\begin{array}{l}\text { Volume of Generator } \\
\text { Volume Reduction }\end{array}$ & percent & 10 to 90 & UNIFORM \\
\hline
\end{tabular}




\section{Fa]1-8ack Position: Build New Tanks}

The existing phase-out basis (Jensen 1995) does not preclude the future need for additional storage tanks. Events could occur creating a need for additional storage capacity. Planning, engineering, construction, permitting, and obtaining approvals contribute to the time period to put tank(s) in service. The number of tanks is dependent upon how much volume is required. A minimum of two tanks is suggested since it is more practical to construct two tanks rather than oniy one. The cost per tank is reduced if more than one is constructed.

\begin{tabular}{|c|c|c|c|c|}
\hline $\begin{array}{l}\text { (VAR. } \\
\text { NO.) }\end{array}$ & VARIABLE NAME & UNITS & RANGE & DISTRIB \\
\hline (132) & $\begin{array}{l}\text { Decide to Build } \\
\text { New Tanks }\end{array}$ & & 0 or 1 & DISCRETE \\
\hline (133) & $\begin{array}{l}\text { Date of Decision } \\
\text { to Build New Tanks }\end{array}$ & & 1996 to 2015 & UNIFORM \\
\hline (134) & $\begin{array}{l}\text { Delay in Putting } \\
\text { New Tanks Into } \\
\text { Service }\end{array}$ & $y r$ & 5 to 10 & UNIFORM \\
\hline (135) & Number of New Tanks & & 2 to 6 & UNIFORM \\
\hline
\end{tabular}

Fall-Back Position: Add Waste to Watchlist Tanks

This fall-back position was temporarily deleted from the list of fall-back positions. Variable 136 has been set in the off position, nullifying variables 137 through 139.

\begin{tabular}{|c|c|c|c|c|}
\hline $\begin{array}{l}\text { (VAR. } \\
\text { NO.) }\end{array}$ & VARIABLE NAME & UNITS & RANGE & DISTRIB \\
\hline (136) & $\begin{array}{l}\text { This variable has been } \\
\text { Decide to Add } \\
\text { Waste to Watchlist } \\
\text { Tanks }\end{array}$ & tempor & $\begin{array}{l}\text { ly set at zero. } \\
0 \text { or } 1\end{array}$ & DISCRETE \\
\hline (137) & $\begin{array}{l}\text { Date of Decision } \\
\text { to Add Waste to } \\
\text { Watchlist Tanks }\end{array}$ & & 1996 to 2015 & UNIFORM \\
\hline (138) & $\begin{array}{l}\text { Delay in Using } \\
\text { Watchlist Tanks }\end{array}$ & $y r$ & 0 to 5 & UNIFORM \\
\hline (139) & $\begin{array}{l}\text { Volume of Added } \\
\text { Waste to Watchlist } \\
\text { Tanks }\end{array}$ & tanks & 0.1 to $5.0 \mathrm{mgal}$ & UNIFORM \\
\hline
\end{tabular}


Fall-Back Position: Add Waste to IMUST Tanks

There are several IMUSTs that could be used for temporary storage to increase the available storage volume during vulnerable capacity periods. Planning. engineering, construction. permitting, and obtaining approvals contribute to the time period to put IMUSTs in service. An arbitrary volume was represented that is dependent on how many IMUSTs are needed.

\begin{tabular}{|c|c|c|c|c|}
\hline $\begin{array}{l}\text { (VAR. } \\
\text { NO.) }\end{array}$ & VARIABLE NAME & UNITS & RANGE & DISTRIB \\
\hline$(140)$ & $\begin{array}{l}\text { Decide to Add } \\
\text { Waste to IMUST Tanks }\end{array}$ & & 0 or 1 & DISCRETE \\
\hline (141) & $\begin{array}{l}\text { Date of Decision } \\
\text { to Add Waste to IMUST } \\
\text { Tanks }\end{array}$ & & 1996 to 2015 & UNIFORM \\
\hline (142) & $\begin{array}{l}\text { Delay in Using } \\
\text { IMUST Tanks }\end{array}$ & $y r$ & 0 to 5 & UNIFORM \\
\hline (143) & $\begin{array}{l}\text { Volume of Added } \\
\text { Waste to IMUST Tanks }\end{array}$ & tanks & 0.1 to $1.0 \mathrm{mga}]$ & UNIFORM \\
\hline
\end{tabular}

Chemical adjustments, such as precipitation, could be made to reduce incoming volumes. No judgment is made here of the technical feasibility of such volume reduction techniques.

\begin{tabular}{|c|c|c|c|c|}
\hline $\begin{array}{l}\text { (VAR. } \\
\text { NO.) }\end{array}$ & VARIABLE NAME & UNITS & RANGE & DISTRIB \\
\hline (144) & $\begin{array}{l}\text { Decide to Chemically } \\
\text { Adjust Incoming } \\
\text { volume }\end{array}$ & & 0 or 1 & DISCRETE \\
\hline (145) & $\begin{array}{l}\text { Date of Decision } \\
\text { to Chemically Adjust } \\
\text { Incoming Volume }\end{array}$ & & 1996 to 2015 & UNIFORM \\
\hline (146) & $\begin{array}{l}\text { Time to Implement } \\
\text { Chemical Adjustment } \\
\text { to Incoming Volume }\end{array}$ & $y r$ & 0 to 5 & UNIFORM \\
\hline (147) & $\begin{array}{l}\text { Chemicaliy Adjust } \\
\text { Volume Reduction } \\
\text { Factor }\end{array}$ & percent & 20 to 80 & UNIFORM \\
\hline
\end{tabular}


WHC-SD-WM-ER-548 Rev. 0

REFERENCES

Awada1 la. N.G., 1995. Risk Management Workshop Paper. paper for brainstorming session held June 28. 1995, Westinghouse Hanford Company. Richland, Washington.

Jensen, C.E.. 1995. Multi-Function Waste Tank Faci7ity Phase Out Basis, WHC-SD-W236AER-021. Rev. 2. Westinghouse Hanford Company, Richland, Washington. 
WHC-SD-WM-ER-548 Rev. 0

This page intentionally left blank. 
WHC-SD-WM-ER-548 Rev. 0

APPENDIX C

MODEL DESCRIPTION 
WHC-SD-WM-ER-548 Rev. 0

This page intentionally left blank.

C-2 


\section{C.1.0 MODEL DESCRIPTION}

The SIMAN risk-based model assesses risk of off-normal tank system conditions and uncertainties associated with waste volume additions or reductions related to the TWRS Baseline architecture (Figure $\mathrm{C}-1$ ). The model currently ranks important variables and identifies operational periods of vulnerability. Periods of vulnerability indicate that some management actions or fall-back positions may be required. These fall-back positions are included in the model. Further, model refinements and analyses are needed to identify specific fall-back actions to consider for implementation.

The SIMAN model is a high-level simulation that follows the three primary systems as identified for the TWRS baseline system within the TWRS Functions and Requirements (F\&R) document (Lee 1995. Johnson 1996): 1) Tank Waste System; 2) Waste Processing System: and 3) Systems Generated Waste and Excess Facilities System. The OWVP (Strode and Koreski 1995) and the ARES Corporation GPSS model (Thurkow 1995) established the OWVP scenarios performed by these systems. Waste generator interviews, along with MWTF workshops, identified off-normal events and programmatic changes affecting the tank system for risk analysis. Lower level assumptions, model variable ranges, and off-normal events are obtained from additional engineering studies and reports containing past-practice risk analysis data. The model provides input for potential risks and consequences of performing and/or not performing waste volume operations.

The model consists of two main files: the experiment file. "OWVP.EXP." and the model file. "OWVP.MOD." The experiment file defines the variable and the logic element declarations with their default values, if any. The model file contains the logic directing the flow of abstract "entities, " that are implemented according to a schedule. Three submodels were developed to represent the OWVP. These submodels represent three main waste types: aging. complexed. and noncomplexed waste.

Model variables that simulate functions are shown in Table $\mathrm{C}-1$. Data input assumptions are shown in Table $\mathrm{C}-2$.

\section{C.2.0 AGING SUBMODEL TANK}

The aging waste submodel simulates three input and two removal streams of scheduled aging waste. These input and removal streams represent the TWRS architecture functions of retrieve and process tank waste as discussed in the following sections.

\section{C.2.1 RETRIEVE TANK WASTE}

Part of the TWRS function is to retrieve the wastes stored in the SSTS and DSTS and transfer the wastes to treatment systems. 
WHC-SD-WM-ER-548 Rev. 0

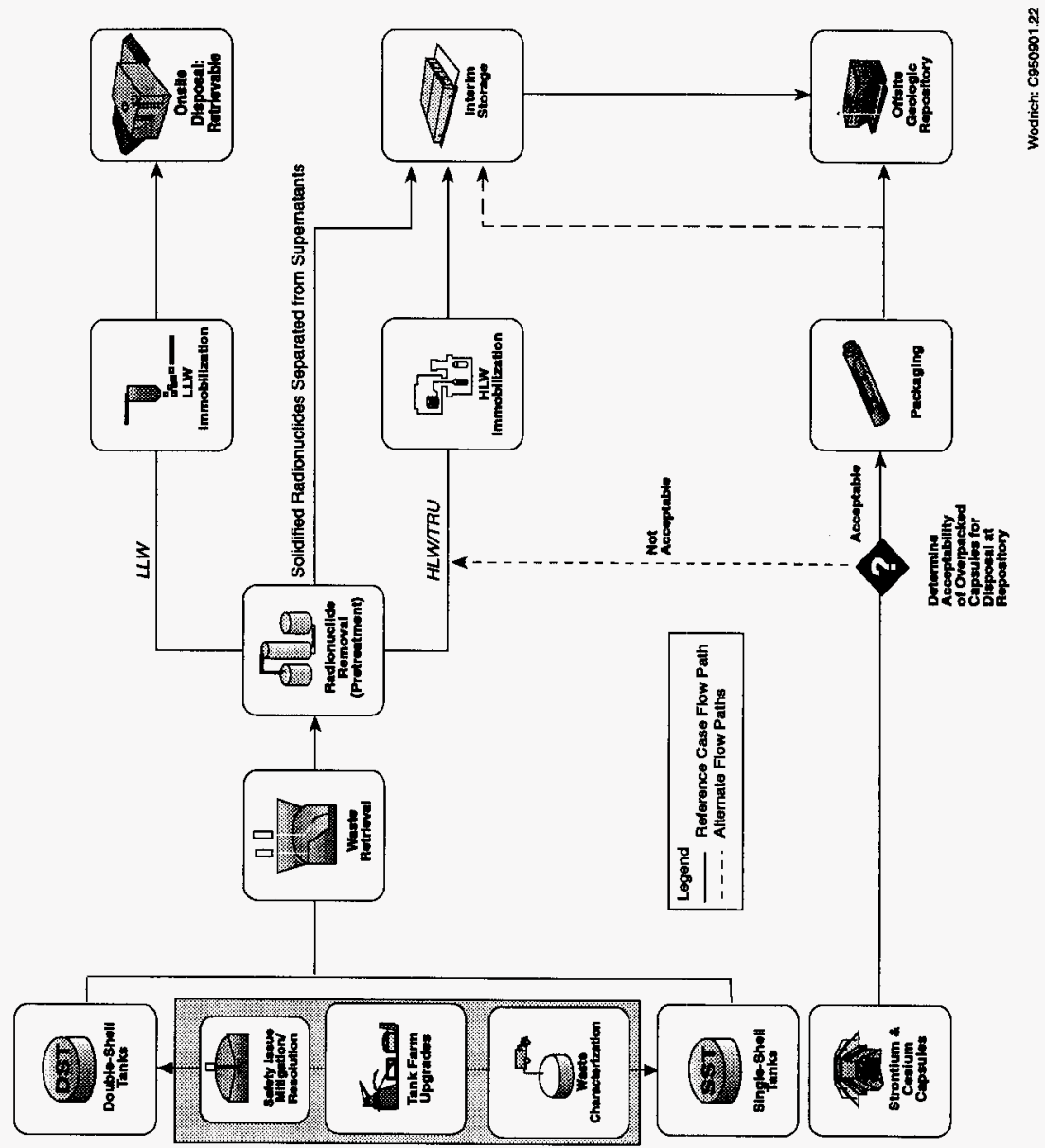

Figure C-1. Summary Tank Waste Remediation System Conceptual Architectures. 
Specifically, tank C-106 solids and cross-site sludge transfer to the vitrification process represent two input streams for aging waste. These two input streams result from high level solids waste retrieval functions. The basis for these two streams is shown as follows.

Basis: $\quad$ Sluicing of tank C-106 solids of predominantly soluble component SST wastes are modeied (Strode and Koreski 1995).

Basis: Cross-site SST sludge transfer to vitrification is modeled. A total of $3909 \mathrm{kgals}$ of waste is scheduled from the year of 2012 to 2015 (Thurkow 1995).

\section{C.2.2 PROCESS TANK WASTE}

Three streams combine to represent the process tank waste architecture for aging waste. Cesium removed to pretreatment, decant operations, and vitrification for disposal are the three processes simulated. The basis for these three streams is shown as follows.

Basis: $\quad$ Cesium removed from pretreatment operations is a scheduled input of $200 \mathrm{kgals}$ increments from the period of 2005 to 2015 (Thurkow 1995). See Section 9.0 of the main text for the latest planning for this stream.

Basis: A decant schedule is identified to remove $647 \mathrm{kgal}$ of aging waste in 1998. This decanted waste volume is transferred to the AP-farm (Thurkow 1995).

Basis: The vitrification process rate is $742 \mathrm{kgals}$. This is the rate of removal for aging waste from the period of 2008 to 2015 (Thurkow 1995).

\section{C.2.3 RISK (AGING)}

Currently, risks associated with the retrieval and processing waste functions are interdependent. Thus, individual contributions to volume exceedence of aging waste tank capacity are analyzed by considering the overall system behavior. Future work is planned to evaluate individual risk contributions of these streams to volume exceedence of aging waste tank capacity.

\section{C.3.0 Complexed SUBMODEL}

The complexed waste submodel simulates five input streams and two removal streams of scheduled complexed waste. These input and removal streams represent to the TWRS architecture functions of manage, retrieve, and process tank waste as discussed in the following sections. 


\section{C.3.1 MANAGE TANK WASTE}

The manage tank waste function manages and stores tank wastes. This includes mitigating and resolving tank waste safety issues. saltwell liquid pumping of SSTs for stabilization. receiving and storing wastes generated during terminal clean out of inactive processing facilities, and waste concentration operations (i.e., 242-A Evaporator). East and west saltwell liquid pumping represent two of the waste type inputs modeled. The basis for saltwell liquid pumping and waste concentration is as follows.

Basis: $\quad$ Saltwell liquid pumping of SST waste (Lee 1995).

Basis: An alternatives evaluation was conducted to select a viable and suitable means for tank waste concentration (Johnson et al.. 1994). The existing 242-A evaporator-crystallizer was selected as the preferred waste concentration mechanism after comparison of alternative mechanisms. (Lee 1995 and Johnson 1996)

\section{C.3.2 RETRIEVE TANK WASTE}

Part of the TwRS function is to retrieve the wastes stored in the SSTS and DSTS and transfer the wastes to treatment systems. The SST solids stream is related to waste volume projected for retrieval of complexed waste. The SST complexed waste volume is hydraulically sluiced and transferred to DSTs designated to receive complexed waste. The basis for this waste retrieval is as follows.

Basis: $\quad$ Remove 99 percent of tank waste and complete retrieval activities by September 2018 (Johnson 1996).

Basis: $\quad$ Although tank $101 \mathrm{SY}$ and $103 \mathrm{SY}$ are designated as input streams for the complexed waste model, neither stream makes a waste addition prior to 2018 for simulation purposes.

\section{C.3.3 PROCESS TANK WASTE}

The primary goal of sludges and solids pretreatment is to reduce the final volume of HLW resulting from treatment of the Hanford Site tank wastes through separation of nonradioactive components of the waste from insoluble radioactively contaminated sludges and solids (Lee 1995). The pretreatment process stream removes waste from the DST system. This stream represents a process tank waste function for the complexed waste submodel. The basis for this stream is as follows.

Basis: Pretreatment process stream (Strode and Koreski 1995 and Thurkow 1995). 


\section{C.3.4 RISK (Complexed)}

Currentiy, risks associated with managing, retrieving, and processing waste functions are interdependent. Thus, individual contributions to volume exceedence of complexed waste tank capacity are analyzed by considering the overall system behavior. Future work is planned to evaluate individual risk contributions of these streams to volume exceedence of complexed waste tank capacity.

\section{C.4.0 NONCOMPLEXED SUBMODEL}

The noncomplexed waste submodel simulates 17 input streams of scheduled noncomplexed waste. These streams represent to the TWRS architecture functions of manage, retrieve, and process tank waste as discussed in the following sections.

\section{C.4.1 MANAGE TANK WASTE}

The manage tank waste function manages and stores tank wastes. This includes mitigating and resolving tank waste safety issues. saltwel1 liquid pumping of SSTs for stabilization. receiving and storing wastes generated during terminal clean out of inactive processing facilities, and waste concentration operations (i.e., 242-A Evaporator).

The model input streams that simulate manage tank waste architecture are provided as follows along with their basis:

$$
\begin{aligned}
& \text { T-Plant } \\
& \text { Purex } \\
& 340 \text { Facility } \\
& \text { AZ-101 Wash } \\
& \text { East Raw Water } \\
& \text { AN-107 Caustic } \\
& \text { 100N Basin } \\
& \text { PFP }
\end{aligned}
$$

Basis: $\quad$ (Johnson 1996)

Basis: $\quad$ These are summarized in Appendix A, B, and C of "A Risk Management Approach to Double-She11 Tank Waste Volume Versus Storage Capacity" (Thurkow 1995). Stream values are supplied from (Strode and Koreski 1995).

\section{C.4.2 RETRIEVE TANK WASTE}

Part of the TWRS function is to retrieve the wastes stored in the SSTs and DSTS and transfer the wastes to treatment systems. The SST solids stream is related to waste volume projected for retrieval of noncomplexed waste. SST noncomplexed waste volume is hydraulically sluiced and transferred to OSTs designated for noncomplexed waste. Tank 102-SY is designated as an input stream for the noncomplexed waste model and makes a waste addition before 2018 for simulation purposes.

Basis: $\quad$ Remove 99 percent of tank waste and complete retrieval activities by September 2018 (Johnson 1996). 


\section{C.4.3 PROCESS TANK WASTE}

The primary goal of sludges and solids pretreatment is to reduce the final volume of HLW resulting from treatment of the Hanford Site tank wastes through separation of nonradioactive components of the waste from insoluble radioactively contaminated sludges and solids (Lee 1995). The pretreatment stream removes waste from the DST system. This stream represents a process tank waste function for the noncomplexed waste submodel.

Basis: $\quad$ Pretreatment process stream (Strode and Koreski 1995 and Thurkow 1995).

\section{C.4.4 RISK (NONCOMPLEXED)}

Currently. risks associated with managing, retrieving, and processing waste functions are interdependent. Thus, individual contributions to volume exceedence of noncomplexed waste tank capacity are analyzed by considering the overall system behavior. Future work is planned to evaluate individual risk contributions of these streams to volume exceedence of noncomplexed waste tank capacity. 
Table C-1. Variable Definitions Used In the SIMAN Model. (Sheet 1)

\begin{tabular}{|c|c|c|}
\hline Variable Name & $\begin{array}{l}\text { LHS Variable } \\
\text { Description }\end{array}$ & Variable Description \\
\hline \multicolumn{3}{|l|}{ FAILURE } \\
\hline \multirow[t]{2}{*}{$\begin{array}{l}\text { lcapnc } \\
\text { lcapc } \\
\text { lcapa } \\
\end{array}$} & $\begin{array}{l}\text { vlhs(1) } \\
\text { vlhs(2) }\end{array}$ & $\begin{array}{l}\text { DST leak occurrence initial rate } \\
\text { DST leak occurrence rate slope(/yr/20yr) }\end{array}$ \\
\hline & $\begin{array}{l}\text { vihs (3) } \\
\text { vlhs(4) }\end{array}$ & $\begin{array}{l}\text { Date of seismic requirements change } \\
\text { Seismic requirements change volume reduction }\end{array}$ \\
\hline edown & $\operatorname{vlns}(5)$ & Duration of extended outage of evaporator \\
\hline levap & $\begin{array}{l}\text { vihs(6) } \\
\text { vihs(7) } \\
\text { vihs(8) } \\
\text { vihs(9) } \\
\text { vihs(10) } \\
\text { vihs(11) } \\
\text { vihs(12) } \\
\text { vihs(13) } \\
\text { vihs(14) } \\
\text { vihs(15) } \\
\end{array}$ & $\begin{array}{l}\text { Failure rate of evaporator for } C Y 1996-1998 . / \mathrm{yr} \\
\text { Failure rate of evaporator for } C Y 1998-2000 . / \mathrm{yr} \\
\text { Failure rate of evaporator for } C Y 2000-2002, / \mathrm{yr} \\
\text { Failure rate of evaporator for } C Y 2002-2004, / \mathrm{yr} \\
\text { Failure rate of evaporator for } C Y 2004-2006 . / \mathrm{yr} \\
\text { Fai7ure rate of evaporator for } C Y 2006-2008, / \mathrm{yr} \\
\text { Fai7ure rate of evaporator for } C Y 2008-2010 . / \mathrm{yr} \\
\text { Failure rate of evaporator for } C Y 2010-2012, / \mathrm{yr} \\
\text { Failure rate of evaporator for } C Y 2012-2014 . / \mathrm{yr} \\
\text { Failure rate of evaporator for } C Y 2014, / \mathrm{yr}\end{array}$ \\
\hline Icross & $\begin{array}{l}\text { VIhs (16) } \\
\text { vlhs (17) } \\
\text { vlhs (18) } \\
\end{array}$ & $\begin{array}{l}\text { 01d cross-site line failure rate, /yr } \\
\text { New cross-site line failure rate, / } / \mathrm{yr} \\
\text { Date of initiation of new transfer line. (Cy) }\end{array}$ \\
\hline privbegins & VIhs(19) & Date privatization begins (cy) \\
\hline retrdelay & vlhs $(20)$ & Time lag for retrieval to begin (yr) \\
\hline $\begin{array}{l}\text { lwacctime } \\
\text { lwacctank } \\
\text { hlvonl ine }\end{array}$ & $\begin{array}{l}\text { v1hs(21) } \\
\text { v1hs(22) } \\
\text { vihs(23) }\end{array}$ & $\begin{array}{l}\text { Time lag for initial liquid waste accumulation(yr) } \\
\text { volumes occupied by liquid waste accumulation (tanks) } \\
\text { Date of online of high capacity vitrification facility } \\
\text { (CY) }\end{array}$ \\
\hline $\begin{array}{l}\text { *tncawuth } \\
\text { tncawcompl } \\
\text { *tncrwauth } \\
\text { tncrwcompl }\end{array}$ & $\begin{array}{l}* v \operatorname{lns}(24) \\
v \operatorname{lhs}(25) \\
\text { *v } \operatorname{lhs}(26) \\
\operatorname{vins}(27) \\
\end{array}$ & $\begin{array}{l}\text { *Authorization delay for NCAW consolidation (CY) } \\
\text { NCAW Consolidation Completion without delay (CY) } \\
\text { *Authorization delay for NCRW consolidation (CY) } \\
\text { NCRW consolidation completion without delay (CY) } \\
\end{array}$ \\
\hline 1sstleak & vlhs (28) & Number of SSTs leaked (1/yr) \\
\hline Cefrac & vlhs (29) & Complexed waste volume reduction factor \\
\hline *1-Cefrac & *vlhs $(30)$ & *1-Cefrac, noncomplex waste volume reduction factor \\
\hline $\begin{array}{l}\text { vpleak } \\
\text { lpleak }\end{array}$ & $\begin{array}{l}\text { Vlhs (31) } \\
\text { vlhs (32) }\end{array}$ & $\begin{array}{l}\text { Volume per pipe break leak (gal) } \\
\text { Frequency of leak occurrence (yr) } \\
\end{array}$ \\
\hline *7facop & *vlhs (33) & *Date facility operation ceased due to break (CY) \\
\hline $\begin{array}{l}\text { vreg } \\
\text { ivreg }\end{array}$ & $\begin{array}{l}\text { vins (34) } \\
\text { vihs (35) }\end{array}$ & $\begin{array}{l}\text { Volume increase due to regulatory change(gal) date } \\
\text { Regulatory change affects volume (CY) }\end{array}$ \\
\hline $\begin{array}{l}\text { dilut } \\
\text { tdilut } \\
\end{array}$ & $\begin{array}{l}\text { vihs(36) } \\
\text { vihs (37) }\end{array}$ & $\begin{array}{l}\text { Dilution factor to becone safe, dimensionless } \\
\text { Date dissolution of safety tanks required (CY) }\end{array}$ \\
\hline $\begin{array}{l}\text { must } \\
\text { tmust } \\
\text { vmust }\end{array}$ & $\begin{array}{l}\text { vihs ( } 38) \\
\text { vlhs (39) } \\
\text { vlhs }(40) \\
\end{array}$ & $\begin{array}{l}\text { Dilution factor of MUSTs } \\
\text { Date dilution of MUSTs required (CY) } \\
\text { Volume of MUST waste to dilute (gal) } \\
\end{array}$ \\
\hline $\begin{array}{l}\text { nchar } \\
\text { vchar } \\
\text { lchar }\end{array}$ & $\begin{array}{l}\text { vlhs (41) } \\
\text { vlhs (42) } \\
\text { vlhs (43) }\end{array}$ & $\begin{array}{l}\text { Number of tanks with new unusual characteristics } \\
\text { Increased volume to treatment from unusual waste } \\
\text { Beginning date for treatment of unusual waste }\end{array}$ \\
\hline vkbasin & $\begin{array}{l}\text { vins (44) } \\
\text { vins (45) }\end{array}$ & $\begin{array}{l}\text { K-Basin waste volume increase factor } \\
\text { Beginning date of added K-Basin waste (CY) }\end{array}$ \\
\hline
\end{tabular}


Table C-1. Variable Definitions Used In the SIMAN Model. (Sheet 2)

\begin{tabular}{|c|c|c|}
\hline Variable Name & $\begin{array}{l}\text { LHS Variable } \\
\text { Description }\end{array}$ & Variable Description \\
\hline $\begin{array}{l}\text { vbplant } \\
\text { tbplant }\end{array}$ & $\begin{array}{l}\operatorname{vlhs}(46) \\
\operatorname{vlhs}(47)\end{array}$ & $\begin{array}{l}\text { B-Plant waste volume increase factor } \\
\text { Beginning date of added B-Plant waste (CY) }\end{array}$ \\
\hline $\begin{array}{l}\text { vpurex } \\
\text { tpurex }\end{array}$ & $\begin{array}{l}\text { vlhs(48) } \\
\text { vlhs (49) }\end{array}$ & $\begin{array}{l}\text { Purex waste volume increase factor } \\
\text { Beginning date to added PUREX waste (CY) }\end{array}$ \\
\hline $\begin{array}{l}\text { loldwas } \\
\text { loldtime }\end{array}$ & $\begin{array}{l}\text { vlhs }(50) \\
\text { vlhs }(51)\end{array}$ & $\begin{array}{l}\text { Discovery of old waste ( } \mathrm{CY} \text { ) } \\
\text { Schedule delay due to discovery of old waste (yr) }\end{array}$ \\
\hline $\begin{array}{l}\text { *rswlp } \\
* 11 \text { tf } \\
\text { *lltftime }\end{array}$ & $\begin{array}{l}\text { vihs (52) } \\
\text { vihs(53) } \\
\text { vihs(54) }\end{array}$ & $\begin{array}{l}\text { Increased rate of saltwe } 11 \text { pumping factor } \\
\text { Frequency of local transfer failure (yr) } \\
\text { Schedule delay per failure (yr) }\end{array}$ \\
\hline $\begin{array}{l}\text { ldisp } \\
\text { ldisptime }\end{array}$ & $\begin{array}{l}\text { vihs (55) } \\
\text { vihs (56) }\end{array}$ & $\begin{array}{l}\text { Date of delay of start of disposal (CY) } \\
\text { Amount of delay due to retrieval and disposal siip (yr) }\end{array}$ \\
\hline 1tpa & vihs(57) & Schedule delay due to TPA mi lestone silp (yr) \\
\hline $\begin{array}{l}\text { Icon } \\
\text { Icontime }\end{array}$ & $\begin{array}{l}\text { v7hs (58) } \\
\text { vihs(59) }\end{array}$ & Date of contractor changeover $(\mathrm{CY})$ \\
\hline $\begin{array}{l}\text { Tindus } \\
\text { lindustime }\end{array}$ & $\begin{array}{l}\operatorname{vihs}(60) \\
\operatorname{vlhs}(61)\end{array}$ & $\begin{array}{l}\text { Date of stoppage due to industrial safety }(C Y) \\
\text { Schedule delay to industrial Safety stoppage (yr) }\end{array}$ \\
\hline $\begin{array}{l}\operatorname{lgc} \\
\text { lgctime }\end{array}$ & $\begin{array}{l}\text { vlhs (62) } \\
\text { v1hs(63) } \\
\text { vlhs }(64) \\
\end{array}$ & $\begin{array}{l}\text { Date of replacement of government customer }(\mathrm{CY}) \\
\text { Schedule delay due to sponsor replacement (yr) }\end{array}$ \\
\hline $\begin{array}{l}\text { lsed } \\
\text { lsedtime } \\
\text { lgos } \\
\text { logstime }\end{array}$ & $\begin{array}{l}\text { v1hs (64) } \\
\text { v1hs(65) } \\
\text { v1hs }(66)\end{array}$ & $\begin{array}{l}\text { Date of stoppage due to System Engineering defect (CY) } \\
\text { Schedule delay due to System Engineering defect (yr) } \\
\text { Date of delay due to government outside scenarios (CY) }\end{array}$ \\
\hline $\begin{array}{l}\text { lseiss } \\
\text { lseitime }\end{array}$ & $\begin{array}{l}\text { vlhs (67) } \\
\text { vlhs(68) }\end{array}$ & $\begin{array}{l}\text { Frequency of significant seismic event } \\
\text { Schedule delay due to significant seismic event (yr) }\end{array}$ \\
\hline $\begin{array}{l}\text { lash } \\
\text { lashtime }\end{array}$ & $\begin{array}{l}\operatorname{vihs}(69) \\
\text { vihs }(70) \\
\end{array}$ & $\begin{array}{l}\text { Frequency of significant ashfall (yr) } \\
\text { Schedule delay due to significant ashfall (yr) }\end{array}$ \\
\hline $\begin{array}{l}\text { isrv } \\
\text { isrvtime }\end{array}$ & $\begin{array}{l}\operatorname{vins}(71) \\
\operatorname{vins}(72) \\
\end{array}$ & $\begin{array}{l}\text { Date of segregation rule violation (CY) } \\
\text { Schedule delay due to new path forward (yr) }\end{array}$ \\
\hline $\begin{array}{l}\text { INDE } \\
\text { INOEt ime }\end{array}$ & $\begin{array}{l}\operatorname{vihs}(73) \\
\operatorname{vins}(74) \\
\end{array}$ & $\begin{array}{l}\text { Date of tank NDE effects (CY) } \\
\text { Tank volumes out of service due to NDE (tanks) }\end{array}$ \\
\hline $\begin{array}{l}\text { ifire } \\
\text { iftime }\end{array}$ & $\begin{array}{l}\operatorname{vlhs}(75) \\
\operatorname{vlhs}(76) \\
\end{array}$ & $\begin{array}{l}\text { Date of fire (CY) } \\
\text { Schedule delay due to fire damage fix (yr) }\end{array}$ \\
\hline \multicolumn{3}{|l|}{ INTERNAL } \\
\hline vtplnt & Vlhs(77) & Distribution for T-Plant waste (gal) \\
\hline v100n & vins (78) & Distribution for N-Basin waste (gal) \\
\hline vaz101 & vihs(79) & Distribution for AZ-101 waste (gal) \\
\hline cfrac & vlhs $(80)$ & Waste evaporate solids fraction \\
\hline csstfrac & vlhs (81) & Percent complexed SST solids \\
\hline$\star$ & vlhs (82) & *Percent noncomplexed SST solids \\
\hline * & vlhs (83) & *Fraction of complexed waste after 2000 in noncomplexed \\
\hline $\begin{array}{l}\text { efracmin } \\
\text { prfracmin } \\
\text { vfracmin }\end{array}$ & $\begin{array}{l}\text { vihs (84) } \\
\text { vihs }(85) \\
\text { vihs }(86) \\
\end{array}$ & $\begin{array}{l}\text { Minimum fraction of waste to evaporator } \\
\text { Minimum fraction of waste to pretreatment facility } \\
\text { Minimum fraction of waste to vitrification facility }\end{array}$ \\
\hline 1csor & vihs $(87)$ & Volume of cesium to pretreatment (kgal) \\
\hline
\end{tabular}


Table C-1. Variable Definitions Used In the SIMAN Mode1. (Sheet 3)

\begin{tabular}{|c|c|c|}
\hline Variable Name & $\begin{array}{l}\text { LHS Variable } \\
\text { Description }\end{array}$ & Variable Description \\
\hline Ivitrate & v1hs (88) & Vitrification rate (kgal) \\
\hline Iprerate & v1hs ( 89 ) & Pretreatment rate (kgal) \\
\hline poros & vihs $(90)$ & West saltwell liquid (porosity, kgal) \\
\hline * & vihs (91) & East saltwell liquid (porosity. kgal) \\
\hline vesolids & v7hs (92) & East SST solids (kgal) \\
\hline v101sy & vihs (93) & West area tank 101SY (kgal) \\
\hline v103sy & vihs (94) & West area tank $1035 \mathrm{Y}$ \\
\hline vbolnt & vihs (95) & B-Plant (kgal) \\
\hline verawwater & v1hs (96) & East raw water usage $\{\mathrm{kga}]$ ) \\
\hline vevflush & vihs $(97)$ & East evaporator flush water(kgal) \\
\hline voeflush & vihs $(98)$ & East flush water (kgal) \\
\hline v102sy & vihs (99) & West tank area $1025 Y$ (kgal) \\
\hline v105aw & vihs $(100)$ & Tank 105AW solids(kgal) \\
\hline vdstw & vins (101) & Dilute DST waste (kgal) \\
\hline vsludge & vins $(102)$ & Sludge to vitrification (kgal) \\
\hline \multicolumn{3}{|l|}{ FALL-BACK } \\
\hline$*_{\text {deops }}$ & vihs (103) & Delay of operations (yr) \\
\hline *1stevap & vlhs (104) & Start evaporator \\
\hline $\begin{array}{l}\text { *buildfac } \\
\text { *tbuild }\end{array}$ & $\begin{array}{l}\text { vlhs }(105) \\
\text { vlhs }(106) \\
\end{array}$ & $\begin{array}{l}\text { Decide to use or build another facility } \\
\text { Delay time to use another facility (yr) } \\
\end{array}$ \\
\hline $\begin{array}{l}\text { swps } \\
1 \text { swps } \\
\text { t tswps } \\
\end{array}$ & $\begin{array}{l}\text { vlhs(107) } \\
\text { vlhs(108) } \\
\text { vlhs(109) } \\
\end{array}$ & $\begin{array}{l}\text { Suspend saltwel1 pumping } \\
\text { Date saltwel1 pumping suspended } \\
\text { Duration of saltwell pumping suspension(yr) }\end{array}$ \\
\hline $\begin{array}{l}\text { *axsite } \\
\text { *raxsite } \\
\text { *taxsite }\end{array}$ & $\begin{array}{l}\text { vlhs }(110) \\
\text { vlhs(111) } \\
\text { vlhs }(112) \\
\end{array}$ & $\begin{array}{l}\text { Implement cross-site above ground transfer } \\
\text { Above ground cross-site transfer rate/normal rate } \\
\text { Duration of above ground cross-site transfer (yr) }\end{array}$ \\
\hline $\begin{array}{l}\text { *localtr } \\
\text { *rlocaltr } \\
\text { *tocaltr }\end{array}$ & $\begin{array}{l}\text { vihs (113) } \\
\text { vlhs(114) } \\
\text { vlhs(115) } \\
\end{array}$ & $\begin{array}{l}\text { Implement local aboveground transfer } \\
\text { Aboveground local transfer rate/normal rate } \\
\text { Duration of aboveground local transfer (yr) }\end{array}$ \\
\hline $\begin{array}{l}\text { tempSSST } \\
\text { ttempSSST } \\
\text { dtempSSST } \\
\text { vtempSSST }\end{array}$ & $\begin{array}{l}\text { vlhs }(116) \\
\text { vlhs }(117) \\
\text { vlhs }(118) \\
\text { vlhs }(119) \\
\end{array}$ & $\begin{array}{l}\text { Decide to use SSTs as temporary storage } \\
\text { Date of decision to use SSTs temporary storage (CY) } \\
\text { Delay for public approval of SST as temporary (yr) } \\
\text { Volume of SST temporary storage (tanks) }\end{array}$ \\
\hline $\begin{array}{l}\text { groutfeed } \\
\text { tgroutfeed } \\
\text { dgroutfeed } \\
\text { ligtogrout }\end{array}$ & $\begin{array}{l}\text { v1hs }(120) \\
\text { v1hs }(121) \\
\text { vihs }(122) \\
\text { vihs }(123) \\
\end{array}$ & $\begin{array}{l}\text { Decide to activate grout program } \\
\text { Date of decision to activate grout program } \\
\text { Delay for public approval of grout program (yr) } \\
\text { DST liquids processed to grout (tanks) }\end{array}$ \\
\hline $\begin{array}{l}\text { liqgroutv } \\
\text { tliggroutv } \\
\text { d]iqgroutv } \\
\text { viiggrout }\end{array}$ & $\begin{array}{l}\text { vihs }(124) \\
\text { vlhs }(125) \\
\text { vlhs }(126) \\
\text { vlhs }(127 \\
\end{array}$ & $\begin{array}{l}\text { Decide to store licuids in existing grout vaults } \\
\text { Date of decision to store liquids in grout vaults } \\
\text { Delay for public approval of grout vault liquids (yr) } \\
\text { volume of temporary storage grout vaults (tanks) }\end{array}$ \\
\hline
\end{tabular}


Table C-1. Variable Definitions Used In the SIMAN Mode1. (Sheet 4)

\begin{tabular}{|c|c|c|}
\hline Variable Name & $\begin{array}{l}\text { LHS Variable } \\
\text { Description }\end{array}$ & Variable Description \\
\hline $\begin{array}{l}\text { lgenvol } \\
\text { tgenvol } \\
\text { dgenvol } \\
\text { fgenvol }\end{array}$ & $\begin{array}{l}\operatorname{vins}(128) \\
\operatorname{vihs}(129) \\
\operatorname{vihs}(130) \\
\operatorname{vihs}(131)\end{array}$ & $\begin{array}{l}\text { Decide generators must reduce volume } \\
\text { Date of decision generators must reduce volume } \\
\text { Time to implement generator volume reduction }(y r) \\
\text { volume of generator volume reduction }(\xi)\end{array}$ \\
\hline $\begin{array}{l}\text { newtanks } \\
\text { tnewtanks } \\
\text { dnewtanks } \\
\text { nnewtanks }\end{array}$ & $\begin{array}{l}\text { vihs }(132) \\
\text { vihs }(133) \\
\text { vihs(134) } \\
\text { vihs (135) }\end{array}$ & $\begin{array}{l}\text { Decide to build new tanks } \\
\text { Date of decision to build new tanks } \\
\text { Delay in putting new tanks into service (yr) } \\
\text { Number of new tanks }\end{array}$ \\
\hline $\begin{array}{l}\text { watchlist } \\
\text { twatchlist } \\
\text { dwatchlist }\end{array}$ & $\begin{array}{l}\text { vlhs }(136) \\
\text { vlhs }(137) \\
\text { vlhs(138) } \\
\text { vlhs(139) }\end{array}$ & $\begin{array}{l}\text { Decide to add waste to watchlist tanks } \\
\text { Date of decision to add waste to Watchlist tanks } \\
\text { Delay in using Watchlist tanks (yr) } \\
\text { Volume of added waste to Watchi ist tanks (tanks) }\end{array}$ \\
\hline $\begin{array}{l}\text { imust } \\
\text { timust } \\
\text { dimust } \\
\text { vimust }\end{array}$ & $\begin{array}{l}\text { vins (140) } \\
\text { vihs(141) } \\
\text { vihs(142) } \\
\text { vlhs(143) }\end{array}$ & $\begin{array}{l}\text { Decide to add waste to IMUSTs } \\
\text { Date of decision added waste to IMUSTs } \\
\text { Delay in using IMUSTs (yr) } \\
\text { Volume of added waste to IMUSTs (tanks) }\end{array}$ \\
\hline $\begin{array}{l}\text { chemvol } \\
\text { tchemvol } \\
\text { dchenvol } \\
\text { fchemvol }\end{array}$ & $\begin{array}{l}\text { vlhs }(144) \\
\text { v1hs }(145) \\
\text { vlhs }(146) \\
\text { vlhs }(147)\end{array}$ & $\begin{array}{l}\text { Decide to chemically adjust to incoming volume } \\
\text { Date of decision chemically adjust to incoming volume } \\
\text { Time to implement chemically adjust to incoming volume } \\
\text { (yr) } \\
\text { Chemically adjust volume reduction factor }(\%)\end{array}$ \\
\hline
\end{tabular}

*Variables are not currently represented in the model. 
WHC-SD-WM-ER-548 Rev. 0

Table C-2. Input Data from OWVP, Rev.21, Table 10 (in kilogallons). (Sheet 1)

\begin{tabular}{|c|c|c|c|c|c|c|c|c|c|c|c|c|c|c|c|c|c|c|c|c|c|}
\hline \multirow[b]{2}{*}{ Waste Stream } & \multicolumn{21}{|c|}{ Year } \\
\hline & 1995 & 1996 & 1997 & 1998 & \begin{tabular}{|l|}
19999 \\
\end{tabular} & \begin{tabular}{|l|}
2000 \\
\end{tabular} & 2001 & \begin{tabular}{|l|l|}
2002 \\
\end{tabular} & 2003 & 2004 & 2005 & \begin{tabular}{|l|}
2006 \\
\end{tabular} & \begin{tabular}{|l|}
2007 \\
\end{tabular} & 2008 & 2009 & 2010 & \begin{tabular}{|l|l|}
2011 \\
\end{tabular} & 2012 & \begin{tabular}{|l|l|}
2013 \\
\end{tabular} & 2014 & 2015 \\
\hline B Plant & 60 & 60 & 60 & 60 & 60 & 60 & 60 & 5 & & & & 5 & 5 & 3! & 3 & 5 & 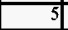 & & 5 & 5 & 3 \\
\hline S Plant & 20 & 25 & 30 & $\overline{30}$ & 30 & 30 & 30 & 30 & 30 & 30 & 30 & 30 & 30 & 30 & 30 & 30 & 30 & 30 & 30 & 30 & 30 \\
\hline T Plant & 28 & 37 & 47 & 49 & 68. & 89 & 112 & 135 & $\overline{180}$ & 180 & 180 & 180 & 180 & 180 & 180 & 180 & 180 & 180 & 180 & 180 & 180 \\
\hline 300 Area & 54 & 54 & 54 & 54 & 54 & 54 & 54 & 54 & 54 & 54 & 54 & 54 & 54 & 54 & 54 & 54 & 54 & 54 & 54 & 54 & 54 \\
\hline 400 Area & 6 & 6 & 6 & 6 & 6 & 6 & 6 & 6 & 6 & 6 & 6 & 6 & 6 & 6 & 6 & 6 & 6 & 6 & 6 & 6 & 6 \\
\hline Tank Farm & 120 & 120 & 120 & $\overline{120}$ & 120 & 120 & 120 & 120 & 120 & 120 & 120 & 120 & 120 & 120 & 120 & 120 & 120 & 120 & 120 & 120 & 120 \\
\hline Evap Flushes & 85 & 100 & 100 & $\overline{100}$ & 100 & 85 & 85 & 85 & 85 & 85 & 85 & 85 & 85 & 85 & 85 & 85 & 85 & 85 & 85 & 85 & 85 \\
\hline PFP Lab & 6 & 6 & 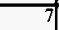 & 7 & 7 & 7 & 6 & 6 & 6 & 6 & 6 & 6 & 6 & 6 & 6 & 6 & 6 & 6 & 6 & 6 & 6 \\
\hline Tk 101-SY Diln/Rtv1 & & & & & & & & & & & 1097 & & & & & & & & & & \\
\hline Tk 103-SY Diln/Rtvl & & & & & & & & & & 748 & & & & & & & & & & & \\
\hline \begin{tabular}{|l|} 
Tk 102-SY Sol. Rtvl \\
\end{tabular} & & & & & 400 & & & & & & & & & & & & & & & & \\
\hline Tk 106-C Sol. Rtrvl & & & 800 & & & & & & & & & & & & & & & & & & \\
\hline Tk 105-AW Sol. Rvl & & & & & 1184 & & & & & & & & & & & & & & & & \\
\hline PUREX TCO & 460.9 & 228.8 & & & & & & & & & & & & & & & & & & & \\
\hline B Plant TCO & & & 99 & 99 & 99 & 99 & 99 & & & & & & & & & & & & & & \\
\hline $100 \mathrm{~N} \mathrm{TCO}$ & & 2160 & & & & & & & & & & & & & & & & & & & \\
\hline SWL Pumping & 206 & 1164 & 2355 & 1541 & 680 & 56 & & & & & & & & & & & & & & & \\
\hline AZ-101 Wash & & & 100 & & & & & & & & & & & & & & & & & & \\
\hline SST Solids & & & & & & & & & & 960 & 712 & 4604 & 6744 & 11290 & 13564 & 6044 & 8468 & 11320 & 11444 & 12296 & 11492 \\
\hline $100 \mathrm{~F} \& \mathrm{H}$ & & & & 763.2 & 360 & & & & & & & & & & & & & & & & \\
\hline AN-107 Caustic & 50 & & & & & & & & & & & & & & & & & & & & \\
\hline Flushes & 123 & 401 & 702 & 498 & 267 & 101 & 92 & 97 & 107 & 107 & 107 & 107 & 107 & 107 & 107 & 107 & 107 & 107 & 107 & 107 & 107 \\
\hline Cs from Pretreat & & & & & & & & & & & 200 & 200 & 200 & 200 & 200 & 200 & 200 & 200 & 200 & 200 & 200 \\
\hline $\begin{array}{l}\text { Xfer SST Sludge to } \\
\text { Vit }\end{array}$ & & & & & & & & & & & & & & & & & & 2514 & & 205 & 1190 \\
\hline Diln of DST Waste & & & & & & & & & & & & 2398 & 2537 & 171 & & & & & & & \\
\hline \begin{tabular}{|l|} 
New Waste Total \\
\end{tabular} & 1219 & 4362 & 4480 & 3327 & 3435 & 707 & 664 & 538 & 593 & 2301 & 2602 & 7795 & 10074 & 12254 & 14357 & 6837 & 9261 & 34627 & 12237 & 13294 & 13475 \\
\hline Waste Before Evap & $242 ! 1$ & 23623 & 25593 & 23270 & 24395 & 22442 & 21806 & 21454 & 21367 & 23118 & 25170 & 28985 & 31649 & 32863 & 36270 & 32167 & 29746 & 32691 & 33206 & 34778 & 36531 \\
\hline
\end{tabular}


WHC-SD-WM-ER-548 Rev. 0

Table C-2. Input Data from OWVP, Rev.21, Table 10 (in kiiogalions). (Sheet 2)

\begin{tabular}{|c|c|c|c|c|c|c|c|c|c|c|c|c|c|c|c|c|c|c|c|c|c|}
\hline & \multicolumn{21}{|c|}{$\overline{\text { Year }}$} \\
\hline \begin{tabular}{|l|} 
Waste Stream \\
\end{tabular} & 1995 & 1996 & 1997 & 1998 & 1999 & 2000 & 2001 & $20 \overline{2}$ & 2003 & 2004 & 2005 & 2006 & 2007 & 2008 & 2009 & 2010 & 2011 & 2012 & 2013 & 2014 & 2015 \\
\hline Evap WVR & 4950 & 2510 & 5650 & 2310 & 2660 & 1300 & 890 & 680 & 550 & 550 & 550 & 540 & 440 & 350 & 340 & 340 & 340 & 380 & 380 & 380 & 620 \\
\hline Cum Evap & 4950 & 7460 & 13110 & 15420 & 18080 & 19380 & 20270 & 20950 & 21500 & 22050 & 22600 & 23140 & 23580 & 23930 & 24270 & 24610 & 24950 & 25330 & 25710 & 26090 & 26710 \\
\hline Pretreatment Loss & & & & & & & & & & & 3430 & 6870 & 10600 & 10600 & 10600 & 10600 & 10600 & 10600 & 10600 & 10600 & 10600 \\
\hline Vit WVR & & & & & & & & & & & & & & & & 742 & 742 & 742 & 742 & 742 & 742 \\
\hline \begin{tabular}{|l} 
Losses \\
\end{tabular} & 4950 & 2510 & 5650 & 2310 & 2660 & 1300 & 890 & 680 & 550 & 550 & 3980 & 7410 & 11040 & 10950 & 10940 & \begin{tabular}{|l|l|}
11682 \\
\end{tabular} & 11682 & \begin{tabular}{|l|l|}
11722 \\
\end{tabular} & \begin{tabular}{|l|l}
11722 \\
\end{tabular} & 11722 & 11962 \\
\hline Net change & -3731 & 1852 & -1170 & 1017 & 775 & -393 & -226 & -142 & 43 & 1751 & -1378 & 385 & -966 & 1304 & 3417 & -4845 & -2421 & 2905 & 515 & 1572 & 1513 \\
\hline $\begin{array}{l}\text { End-of-Year } \\
\text { Inventory }\end{array}$ & 19261 & 21113 & 19943 & 20960 & 21735 & 21142 & 20916 & 20774 & 20817 & 22568 & 21190 & 21575 & 20609 & $\overline{21913}$ & 25330 & 20485 & 18064 & 20969 & 21484 & 23056 & 24569 \\
\hline
\end{tabular}




\section{WHC-SD-WM-ER-548 Rev. 0 \\ REFERENCES}

Johnson, M.E., 1996. Tank Waste Remediation System Baseline System Description, WHCEP-0856. Revision 1, Westinghouse Hanford Company. Richland, Washington.

Johnson, M.E., et a1.. 1994, Tank Waste Decision Analysis Report. WHC-EP-0167. Westinghouse Hanford Company. Richland. Washington.

Lee, A.K. . 1995. TWRS Baseline System Description, WHC-SD-WM-TI-657, Westinghouse Hanford Company. Richland. Washington.

Thurkow. T.J., R.L. Fritz, and G.A. Cole, 1995. A Risk Management Approach to DoubleShe77 Tank Waste Volume Versus Storage Capacity, WHC-SD-WM-ER-527, Revision 0. Westinghouse Hanford Company. Richland, Washington.

Strode. J.N. and G.M. Koreski, 1995. Operational Waste Volume Projection, WHC-SD-WMER-029. Revision 21. Westinghouse Hanford Company. Richland. Washington. 
WHC-SD-WM-ER-548 Rev. 0

This page intentionally left blank. 
WHC-SD-WM-ER-548 Rev. 0

APPENDIX D

TREATMENT OF RANDOM FAILURES

D-1 
WHC-SD-WM-ER-548 Rev. 0

This page intentionally left blank. 


\section{Treatment of Random Failures}

Several items in the simulation were treated with respect to random failures. The operation of the evaporator, the operation of pretreatment, the cross-site transfer system, and the occurrence of a DST leak were assigned a failure rate $(\lambda)$. It was assumed that failure rates were constant over some prescribed time interval. Therefore, the mean time to failure is given as $1 / \lambda$ and the probability of failure is exponential within the time interval.

In the simulation, failures were represented stochastically by failing a system randomly at the end of each quarter year the system is operational and if the

$$
r(0,1)+\left(1-e^{-\lambda \Delta t}\right)>1
$$

expression is true. Where $r(0,1)$ is a uniform deviate between zero and one. lambda is the failure rate, and Delta $t$ is one quarter year. For both the evaporator and cross-site transfer. both lambda and the outage time were introduced externally from the LHS to sample ranges of possible values. Those value ranges are given in the input variable distribution section (Appendix A).

The tank leaks were represented by assigning a leak rate and a positive leak rate slope that approximated the effect of aging. Both the leak rate and the aging slope were also introduced externally from the LHS. When a leak event occurred. one million gallons of capacity were removed from service for the corresponding waste type. 
WHC-SD-WM-ER-548 Rev. 0

This page intentionally left blank.

D-4 
WHC-SD-WM-ER-548 Rev. 0

APPENDIX E

TEST RESULTS

E-1 
WHC-SD-WM-ER-548 Rev. 0

This page intentionally left blank. 


\section{Test Results}

The SIMAN risk-based model has various results for each development phase or stage. Phase I results compare GPSS runs to SIMAN runs at a 90 percent confidence interva1. The GPSS confidence interval was determined with 30 runs while the SIMAN model used 500 runs. Phase II results present not only a subset of four off-normal conditions simulated but also range to 30 off-normal events. Volume versus capacity and event trees for these off-normal conditions are presented in the sections below.

Phase I (Figures 5-1, 5-2, 5-3, located in Section 5.0) captures differences in each simulation model for GPSS conversion into SIMAN language. Figure 5-1 represents aging waste. Due to the small number of input streams and no concentration of aging waste (i.e., no evaporator requirement), the GPSS and SIMAN results are very similar. Note that the GPSS run set results using 30 replications and the SIMAN run set results using 500 replications are almost indistinguishable for aging waste. But for complexed and noncomplexed runs, 500 replications are required for accurate statistics. In Figure 5-2 for instance, the SIMAN model captures failures in the evaporator. Volume only decreases when the evaporator is working and any missed campaign added to the next year's schedule. It is assumed that an evaporator campaign can handle up to $10,000 \mathrm{kgals}$ per year. Note that both GPSS and SIMAN indicate that noncomplexed waste tanks have enough spare capacity until the end of 2015. Then, former noncomplexed tanks return from the complexed waste reservoir and aid in the retrieval processes.

Phase II model analysis incorporated four off-normal operations. These offnormal operations presented another degree of difficulty. From evaporator downtime, the model incorporated vitrification and pretreatment operation failures, of $f$ setting waste volume schedules, chemical reductions, volume additions, capacity increases, and other reductions that could probabilistically occur simultaneously. on and off switches were developed to allow synthesis of Phase II results for comparison to Phase I results.

These two processes also have some maximum volume capacity limit imposed for rescheduling waste.

To analyze these four off-normal events a new methodology was devised. Aithough 500 run sets simulated the uncertainty of equipment failures, spurious correlations were possible. To minimize such correlations the Latin Hypercube Sampler (LHS) was introduced. The LHS minimized the number of correlations between variables while supplying 500 values per variable.

The four off-normal volume vs capacity results are presented in two forms. (Figure E-1) represents a graphical representation of the complexed waste model. 


$$
\text { WHC-SD-WM-ER-548 Rev. } 0
$$

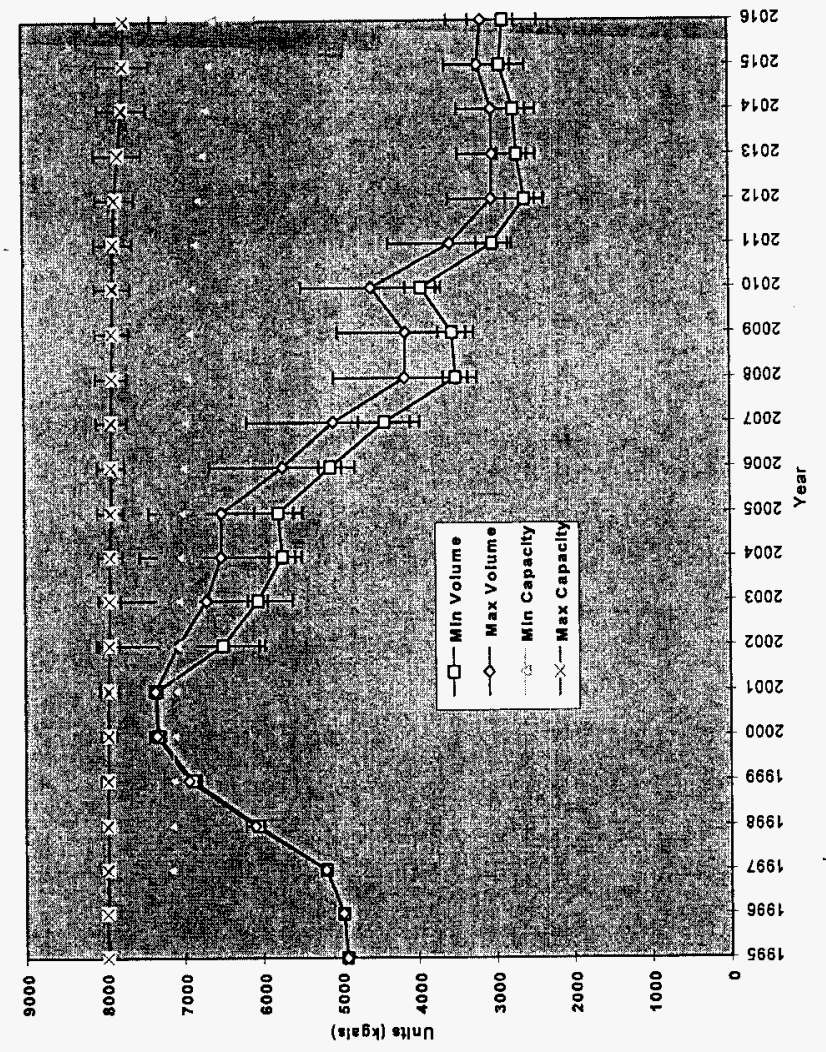

Figure E-1. Volume of Complexed Waste Versus Capacity. 
WHC-SD-WM-ER-548 Rev. 0

APPENDIX $F$

GENERAL DESCRIPTION OF LATIN HYPERCUBE SAMPLER (LHS) 
WHC-SD-WM-ER-548 Rev. 0

This page intentionally left blank. 
WHC-SD-WM-ER-548 ReV. 0

\section{F.1.0 INTRODUCTION}

This appendix gives an introduction to the use of Latin Hypercube Sampling (LHS) adapted from the LHS code manual written by Iman (1985) for the USNRC.

LHS is a type of stratified Monte Carlo sampling that is a popular and effective alternative to the response surface replacement approach. As originally described (Mckay et a1. 1979). L.HS operates in the following manner to generate a sample of size $n$ from the $k$ variables $X_{1} \ldots \ldots X_{k}$. The range of each variable is divided into $n$ nonoverlapping intervals on the basis of equal probability. One value from each interval is selected at random with respect to the probability density in the interval. The $n$ values thus obtained for $x_{1}$ are paired in a random manner with the $n$ values of $x_{2}$. These $n$ pairs are combined in a random manner with the $n$ values of $x_{3}$ to form $n$ triplets. and so on. until a set of $n k$-tuples is formed. This set of $k$-tuples is the LHS. Thus, for given values of $n$ and $k$, there exist $(n !) * *(k-1)$ possible interval combinations for a LHS.

Because of the random pairing of intervals in the mixing process, there exists the possibility of inducing undesired pair-wise correlations among some of the variables in a LHS. just as there is in Monte Carlo sampling. This is more likely to occur if $n$ is small. Such correlations can be avoided by modifying the LHS by restricting the $(n !)^{* *}(k-1)$ possible interval pairings through the use of a technique introduced by Iman and Conover (1982) and implemented by the computer program (Iman 1984) developed at Sandia National Laboratories. Restricting the pairing in this manner preserves the fundamental nature of LHS but replaces the random matching of intervals with a method that keeps all of the pair-wise rank correlations among the $k$ input values very close to zero, and thus ensures that no unwanted large pair-wise correlations will exist between input variables. Additionally. the restricted pairing technique in Iman and Conover (1982) can be used to induce correlation when desired.

In uncertainty analysis associated with LHS, it is desired to estimate the distribution function and the variance for the particular output variables $Y$ under consideration. Due to the probabilistic nature of LHS, it is possible to estimate these entities directly from the model output associated with the sample just as in simple Monte Carlo Sampling.

An evaluation of LHS applicability can be found from a comparison with other sampling techniques (Iman and Helton 1987). 


\section{F.2.0 LHS THEORY}

This section describes how to use the latest version of a computer program for the generation of multivariate samples either completely at random or by a constrained randomization (LHS). This program has been developed at Sandia National Laboratories and replaces the previous program described in Iman et a1.. (1980). Every attempt has been made to make the present program portable and user-friendiy while at the same time expanding the capability of the program to include additional sampling distributions. A complete listing of the computer code is given in the code manual (Iman 1984). The parameters needed by the program are described in Section F.3.0 and are followed by a more detailed description of the various distributions built into the program in Section 4.0 .

The situation addressed by the computer program is as follows. There is a variable of interest. $Y$. that is a function of other variables $X_{1}, X_{2}$. $X_{k}$. This function may be quite complicated, for example, a computer model. A question to be investigated is: How does $Y$ vary when the $X$ 's vary according to some assumed joint probability distribution? Related questions are: What is the expected value of $Y$ ? What is the 99th percentile of $Y$ ? and so forth.

A conventional approach to these questions can be found within the Monte Carlo program. By sampling repeatedly from the assumed joint probability density function of the $X s$ and evaluating $Y$ for each sample. the distribution of $Y$, its mean and percentiles can be estimated. This is one option provided by the program for generating the $X_{s}$. The program output, for example n Monte Carlo repetitions, is a set of $k$-dimensional vectors of input variables.

An alternative approach. which can yield more precise estimates, is to use a constrained sampling scheme. One such scheme, developed by McKay, Conover, and Beckman (1979), is LHS. LHS selects $n$ different values from each of $k$ variables $x_{1}$, $\ldots . X_{k}$ in the following manner. The range of each variable is divided into $n$ nonoverlapping intervals on the basis of equal probability. One value from each interval is selected at random with respect to the probability density in the interval. The $n$ values thus obtained for $x_{1}$ are paired in a random manner (equal and likely combinations) with the $n$ values of $x_{2}$. These $n$ pairs are combined in a random manner with the $n$ values of $x_{3}$ to form $n$ triplets, and so on. until $n$ k-tuplets are formed. This is LHS. It is convenient to think of L.HS, or a random sample of size $n$, as forming an $n \times k$ matrix of input where the ith row contains specific values of each of the $k$ input variables to be used on the ith run of the computer model.

The LHS technique has been applied to many different computer models since 1975. The results of an application of LHS to a large computer model can be found in Steck et al.. (1976). A more detailed description of LHS with application to sensitivity analysis techniques can be found in Iman et a1.. (1981a, 1981b). A tutorial on LHS may be found in Iman and Conover (1982b). A comparison of LHS with other techniques is given in Iman and Helton (1983). 


\section{WHC-SD-WM-ER-548 Rev. 0}

\section{F.3.0 EXAMPLE OF LHS}

To help clarify how intervals are determined in LHS, consider a simple example where it is desired to generate a LHS of size $n=5$ with two input variables. Assume that the first random variable $X_{1}$ has a normal distribution concentrated on the range from $A$ to $B$. In this program. the following interpretations (not subject to change by the user without modifying the code) are given to $A$ and $B$ for both the normal and lognormal distributions, namely

$$
P\left(X_{1} \leq A\right)=.001 \text { and } P\left(X_{1} \geq B\right)=.001 \text {. }
$$

where $P(E)$ denotes the probability of event $E$. That is. A is defined as the 001 quantile and $B$ is defined as the .999 quantile of the distribution of $X_{1}$. Thus. $P(A \leq$ $\left.X_{1} \leq B\right)=.998$. so both the normal and lognormal distributions are truncated slightly in the program. That is, the sampling procedure excludes values outside the interval $[A, B]$. These definitions of $A$ and $B$ imply that the mean of the normal distribution is given by $\mu=(A+B) / 2$ and since for a standardized normal variable z.

$$
P(Z \leq-3.09)=.001
$$

it follows that the standard deviation of the desired truncated normal distribution is given (to a close approximation) by

$$
\sigma=(B-\mu) / 3.09=(B-A) / 6.18 \text {. }
$$

With the parameters $\mu$ and $\sigma$ thus defined. the endpoints of the intervals are easily determined. The intervals for $n=5$ are illustrated in Figure $F-1$ in terms of both the density function and the more easily used cumulative distribution function (cdf). If the distribution were not truncated, then the intervals in Figure $\mathrm{F}-1$ would satisfy

$$
\begin{gathered}
P\left(A \leq X_{1} \leq C\right)=P\left(F \leq X_{1} \leq B\right)=.199 \\
\approx P\left(C \leq X_{1} \leq D\right)=P\left(D \leq X_{1} \leq E\right)=P\left(E \leq X_{1} \leq F\right)=.2 .
\end{gathered}
$$

Accounting for truncation required dividing these probabilities by .998. Thus, for all practical purposes, the five intervals correspond to 20 percent probability.

It shall be assumed in this example that the second random variable, $x_{2}$. has a uniform distribution on the interval from $G$ to $H$. The corresponding intervals used in the LHS for $X_{2}$ are given in Figure F-2 in terms of both the density function and the cdf. 


\section{WHC-SD-WM-ER-548 Rev. 0}

The next step in obtaining the LHS is to pick specific values of $x_{1}$ and $x_{2}$ in each of the five respective intervals. This selection should be done in a random manner with respect to the density in each interval; that is, the selection should reflect the height of the density across the intervar. For example, in the (A,C) interval for $X_{1}$, values close to $C$ will have a higher probability of selection than will those values close to $A$. Next, the selected values of $X_{1}$ and $X_{2}$ are paired to form the required five input vectors. In the original concept of LHS as out7ined in Mckay, Conover, and Beckman (1979), the pairing was done by associating a random permutation of the first $n$ integers with each input variable. For purposes of illustration. in the resent example consider two random permutations of the integers (a). 2, 3. 4, 5) as follows:

Permutation Set No. 1: (3, 1, 5, 2, 4)

Permutation Set No. 2: (2, 4, 1, 3, 5) 

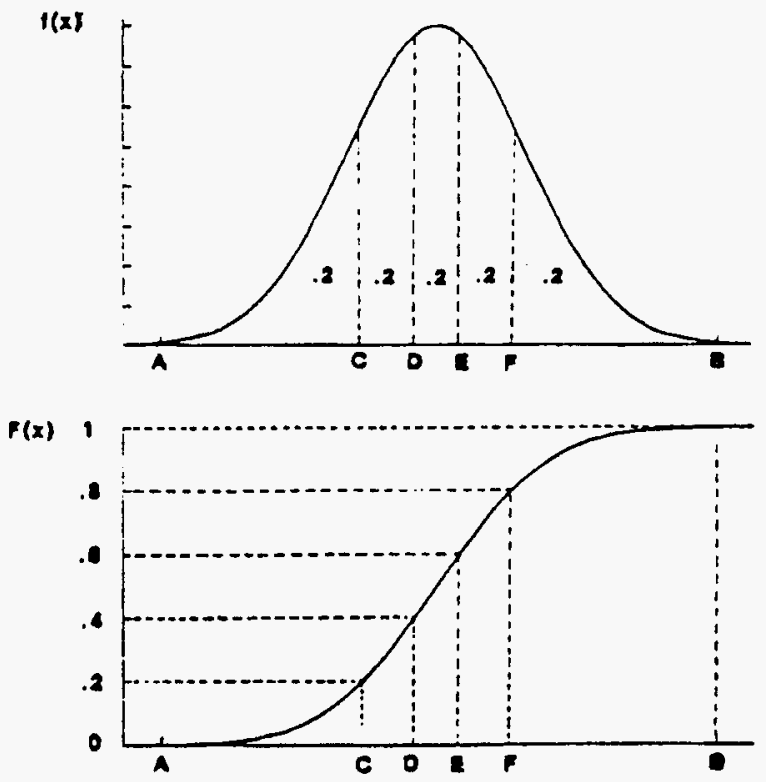

Figure F-1. Intervals Used with a LHS of Size $n=5$ in Terms of the Density Function and Cumulative Distribution

Function for a Normal Random Variable. 

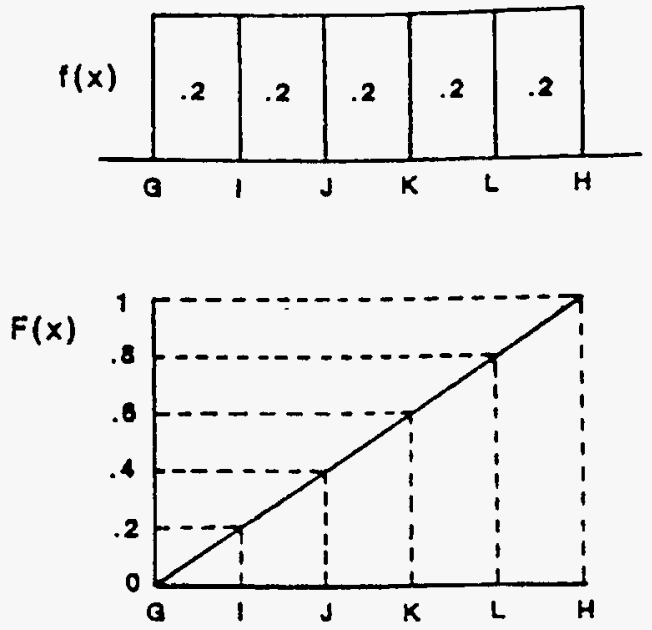

Figure F-2. Intervals Used with a LHS of Since $n=5$ in Terms of the Density Function and Cumulative Distribution Function for a Uniform Random Variable.

By using the respective position within these permutation sets as interval numbers for $X_{1}$ (Set 1 ) and $x_{2}$ (Set 2). the following pairing of intervals would be formed.

Interval No. Interval No.

Computer Run No. Used for $X_{1}$ Used for $X_{2}$

$\begin{array}{lll}1 & 3 & 2 \\ 2 & 1 & 4 \\ 3 & 5 & 1 \\ 4 & 2 & 3 \\ 5 & 4 & 5\end{array}$


Thus, on computer run number 1 , the input vector is formed by selecting the specific value of $X_{1}$ from interval number 3 ( $D$ to $E$ ) and pairing this value with the specific value of $x_{2}$ selected from interval number 2 ( $I$ to $\mathrm{J}$ ), etc. Once the specific values of each variable are obtained to form the five input vectors, a two-dimensional representation of the LHS can be made, such as given in Figure $F-3$.

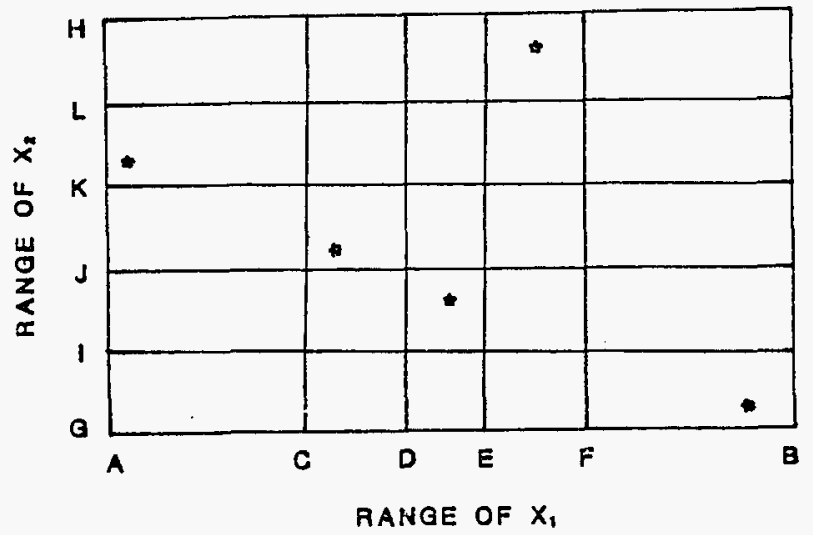

Figure F-3. A Two-Dimensional Representation of One Possible LHS of Size 5 Using $X_{1}$ and $X_{2}$.

Note in Figure $F-3$ that all of the intervals for $X_{1}$ have been sampled and the same is true of $x_{2}$. In general. a set of $n$ LHS points in $k$-dimensional Euclidean space contains one point in each of the intervals for each of the k variables.

\section{F.4.0 OBTAINING SPECIFIC VALUES}

To illustrate how the specific values of a variable are obtained in LHS. consider the following example. Suppose it is desired to obtain a LHS of size $n=5$ from a norilal distribution on the ran that these two limits are taken to represent the lower and upper 001 quantiles, respectively. Therefore, the random variable has a mean of five and a variance of 2.613 as indicated in Figure F-4. These points, together with the density characteristics of the normal distribution, allow for the definition of the equal probability interval endpoints. These endpoints are shown in Figure F-4 in terms of a density function. The next step is to randomy select an observation within each of the intervals. This selection is not done uniformly within the 
intervals shown in Figure $F-4$, but rather it is done relative to the distribution being sampled (in this case, the normal distribution). This means that the sampling is done uniformly on the vertical axis of the cof as shown in Figure F-4.

Therefore, to get the specific values, $n=5$ randomly selected uniform $(0,1)$ numbers (Urn, $-i=1,2,3,4,: r)$ ) are obtained to serve as probability levels. These probabilities are then scaled by

$$
P_{m}=U_{m}(.2)+(m-1)(.2) \quad m=1,2,3,4,5
$$

This ensures that exactly one probability, $P_{\text {n }}$ will fall within each of the five intervals $(0, .2) .(.2, .4),(.4, .6),(.6, .8)$ and $(.8,1)$. The values $P$ are used with the inverse normal distribution function to produce the specific values to be used in the LHS. Note that exactly one observation is taken from each interval shown in Figure F-4. The entire process is shown in Table F-1. Figure F-4 makes it clear that when obtaining a LHS, it is easier to work with the cdf for each variable. This is the approach used in the computer program, rather than defining the endpoints of the intervals on the x-axis.

Figure F-4 shows how one input variable having a normal distribution is sampled with LHS. This procedure is repeated for each input variable, each time working with the corresponding cumulative distribution function. If a random sample is desired. then it is not necessary to divide the vertical axis into $n$ intervals of equal width. Rather, $n$ random numbers between 0 and 1 are obtained and each is mapped through the inverse distribution function to obtain the specific values. The final step in the sampling process involves pairing the selected values. 
WHC-SD-WM-ER-548 Rev. 0
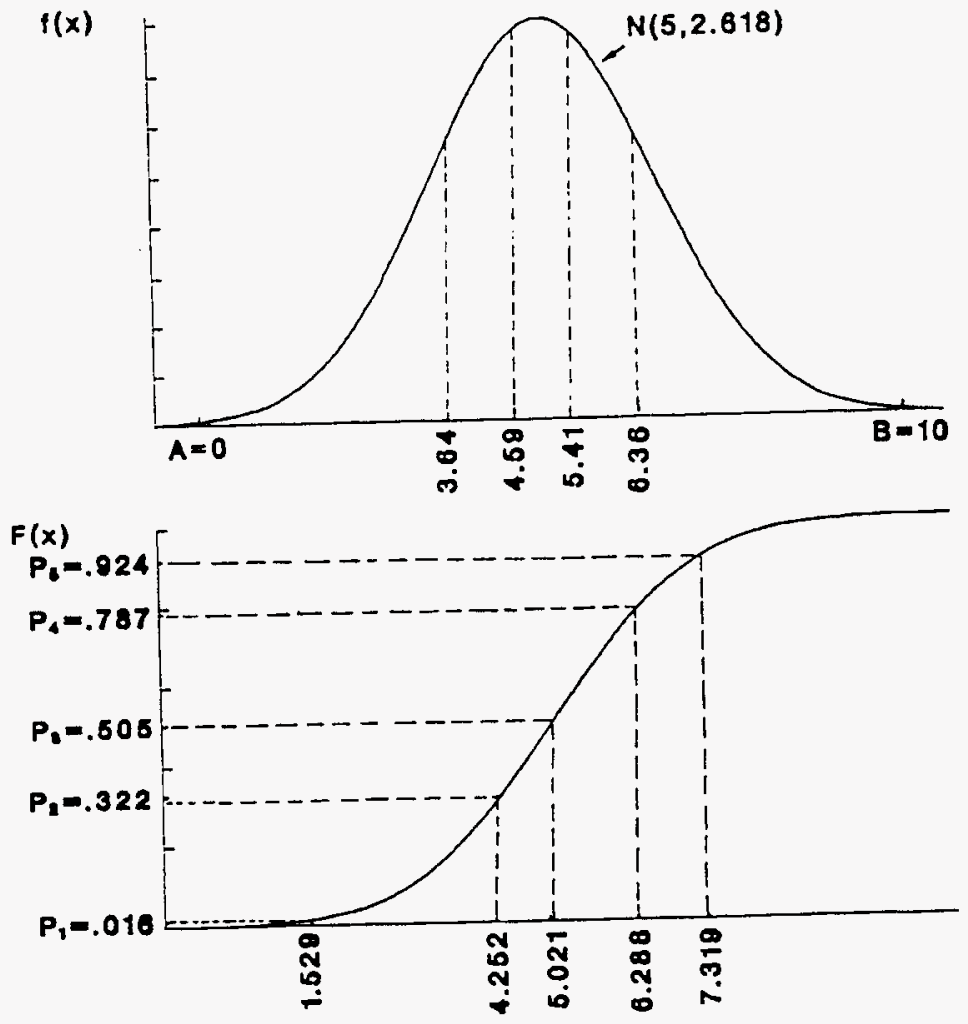

Figure F-4. Interval Endpoints Used with a LHS of Size 5 (top) and Specific Values of $X$ Selected Through the Inverse of the Distribution Function (bottom). 
Table F-1. One Possible Selection of Values for a LHS of Size 5 from a Normal Distribution on the Interval $(0.10)$.

\begin{tabular}{|c|c|c|c|c|}
\hline $\begin{array}{c}\text { Interval } \\
\text { Number } \\
m\end{array}$ & $\begin{array}{c}\text { Uniform }(0.1) \\
\text { Random No. } \\
U_{\mathrm{m}}\end{array}$ & $\begin{array}{c}\text { Scaled } \\
\text { Probabilities with } \\
\text { the Interval } P_{m} \text { - } \\
U_{m}(.2)+ \\
(m-1)(.2) \\
\end{array}$ & $\begin{array}{l}\text { Corresponding } \\
\text { Standard Normal } \\
\text { Value (z-score) } \\
\text { From the Inverse } \\
\text { Distribution }\end{array}$ & $\begin{array}{c}\text { Corresponding } \\
\mathrm{N}(5,2.618) \\
\text { Observation } \\
\text { Within the } \\
\text { Intervals } \\
\end{array}$ \\
\hline 1 & 0.12713 & 0.016 & -2.144 & 1.529 \\
\hline 2 & 0.57689 & 0.322 & -0.462 & 4.252 \\
\hline 3 & 0.03652 & 0.505 & 0.013 & 5.021 \\
\hline 4 & 0.29372 & 0.787 & 0.796 & 6.288 \\
\hline 5 & 0.39332 & 0.924 & 1.433 & 7.319 \\
\hline
\end{tabular}

It should be noted that even though two variables are sampled independently and paired randomly, the sample correlation coefficient of the $n$ pairs of variables in either a random sample or a LHS wi11, in genera?, not equal zero, due to sampling fluctuations. In order to obtain a sample in which the sample correlations more nearly match the assumed. or intended. correlations. Iman and Conover (1982a) proposed a method for restricting the method in which the variables are paired. The effect of this restriction on the statistical properties of the estimated distribution of $Y$, its mean, and percentiles is not known but is felt to be small. The pairing of variables in the program can be done either randomly or by the restriction procedure through use of an input parameter. which is explained in the next section.

Additionally, the restricted pairing procedure of Iman and Conover (1982a) can be used to induce a user-specified correlation among selected input variables through use of another input parameter explained in the next section. However, it should be pointed out that such induced correlations are based on the nonparametric technique known as rank correlation. Such a measure is used since it remains meaningful in the presence of non-normal distributions on the input variables.

As a final note, if a correlation structure is not specified by the user. then the program computes a measure for detecting large pair-wise correlations. This measure is known as the variance inflation factor (VIF) and is defined as the largest element on the diagonal of the inverse of the correlation matrix. As the VIF gets larger than one. there may be some undesirably large pair-wise correlations present. Marquardt and Snee (1975) deal with some very large VIFs (> $2 \times 10^{6}$ ) and provide a very readable explanation on reasonable sizes of VIFS. Marquardt (1970) indicates that there can be serious collinearity (i.e.. large pair-wise correlations present) for VIF $>10$. Thus, there is certainly no problem as long as the VIF is close to one. The VIF appears as part of the computer printout when the user requests the correlation matrix to be printed, given that no correlation structure has been specified by the user. 


\section{F.5.0 INPUT PARAMETERS}

The LHS program requires certain parameters to be defined in order to generate one or more LHS or random samples. The program recognizes 17 keywords (no abbreviations allowed). which dictate the characteristics of the generated sample(s) such as type of sample (LHS or random), sample size, number of samples desired. correlation structure on input variables, and type of distribution specified on each variable. Other keywords are used to control the output from the printer. If the keyword requires accompanying numerical values, these values are input using list-directed read statements. In all cases, the generated sample( $\$$ ) are automatically written on an output file in unformatted binary and it is up to the user to take the steps necessary to save the file. The only restriction on the keywords is that there can be no leading blanks and at least one blank must follow each keyword.

There are a number of internal checks built into the program to ensure that the input parameters have been correctly specified. In the event an improper specification is detected, an appropriate message is printed and the execution of the program is terminated.

The role of each keyword wi1l now be explained. For purposes of illustration, Table F-2 gives an example setup that uses 16 of the 17 keywords to generate two random samples of size 20 each from 9 input variables, some of which are correlated with one another. 


$$
\begin{aligned}
& \text { WHC-SD-WM-ER-548 Rev. } 0 \\
& \text { Table F-2. Parameter Setup for Generating Two } \\
& \text { Random Samples of Size } 20 \text { Each. }
\end{aligned}
$$

1. TITLE - SETUP FOR GENERATION OF A RANDOM SAMPLE

2. RANOOM SAMPLE

3. NOBS 20

4. NREPS 2

5. RANDOM SEED - 898079140

6. NORMAL

OPTIONAL FIELD FOR NAMING INPUT VARIABLE 1

7. $12 \quad 56$

8. LOGNORMAL

9. .012 .13

10. UNIFORM

11. 13

12. LOGUNIFORM

13. $6.0 \mathrm{E} 7$ 8.1E10

14. UNIFORM*

15.3

16. LOGUNIFORM* 569

17. $5 \begin{array}{llllll}5 & 3 & 3 & 4 & 4 & 6\end{array}$

18. TRIANGULAR

OPTIONAL FIELD FOR NAMING INPUT VARIABLE 2

OPTIONAL FIELD FOR NAMING INPUT VARIABLE 3

19. $10 \quad 15 \quad 30$

20. BETA

21. $\begin{array}{llll}10 & 45 & .5 & 1.5\end{array}$

22. USER DISTRIBUTION OPTIONAL FIELD FOR NAMING INPUT VARIABLE 9

23. 4

24. $0 \quad .2$

25. $1 \quad .3$

26. 2.4

27. 3.1

28. CORRELATION MATRIX

$\begin{array}{lllllllllll}29 . & 3 & 1 & 2 & .8 & 1 & 5 & .7 & 2 & 5 & .6\end{array}$

30. OUTPUT CORR HIST DATA

OPTIONAL FIELD FOR NAMING INPUT VARIABLE 4

OPTIONAL FIELD FOR NAMING INPUT VARIABLE 5 $\begin{array}{llll}1 & 2 & 3 & 4\end{array}$

OPTIONAL FIELD FOR NAMING INPUT VARIABLE 6 $\begin{array}{llllll}5000 & 5500 & 6000 & 6500 & 7000 & 7500\end{array}$ OPTIONAL FIELD FOR NAMING INPUT VARIABLE 7

OPTIONAL FIELD FOR NAMING INPUT VARIABLE 8

30. 
TITLE

This keyword can be followed with alphanumeric data to help describe the application of the sample (see line 1 of Table F-2). This information will be printed as a one-line header on each page of the output. This keyword is optional. If it is omitted, a blank header is generated at the top of each page.

RANDOM SAMPLE

If this keyword is present, a random sample(s) is generated. If it is omitted. a L.HS(s) is generated.

$\star \star \star$ This keyword is required $* \star * *$

This keyword must be followed by a positive integer that specifies the desired sample size. The maximum number of observations, currentiy 1,000, is easily changed (see the discussion elsewhere in this report).

NREPS

This keyword can be used to generate multiple samples. It is optiona 1, but when present. it must be followed by a positive integer to specify the desired number of samples (each of size NOBS). If it is omitted, one sample is generated. If NREPS is followed by the positive integer $m$. then $m$ complete samples (each of size NOBS) will be written back to back on the output file.

RANDOM SEED

$\star * *$ This kevword is required $* * *$

This keyword must be followed by an integer within the machine's range. For example, within plus or minus $2^{31}-1$ on the VAX 11/780. within plus or minus $2^{48}$ - 1 on the CDC 7600, and within plus or minus $2^{63}$ - 1 on the CRAY 1 . This number is used as a starting point for the random number generator and is printed at the beginning of each sample. If NREPS specifies a number greater than 1 , the current value of the random seed is retrieved at the start of the generation of each new sample. The new value is printed at the beginning of the new sample so that any one desired sample can be regenerated by rerunning the program with the new seed and with the NREPS parameter omitted (or having NREPS 1).

\section{CORRELATION MATRIX}

This keyword is used when it is desired to induce a rank correlation structure among the input variables using the restricted pairing technique of Iman and Conover (1982a). It should be followed by one or more lines providing the desired rank correlations among those pairs of input variables having a rank correlation other than zero. The first value to be supplied is the number of pairwise rank correlations, $\mathrm{m}$. followed by m ordered triples containing the numbers of the variables being correlated along with the required rank correlation. Currently. the number of pairwise rank correlations is limited to 50. For example, line 29 of Table F-2 first indicates that three pairs of 
variables are to be correlated. The next information indicates that variables 1 and 2 are to have a rank correlation of .8. then variables 1 and 5 are to have a rank correlation of .7, and finally variables 2 and 5 are to have a rank correlation of .6. If this keyword is omitted, all pairwise correlations are assumed to be zero.

The user should note that the restricted pairing technique of Iman and Conover requires $n>k$. That is, the technique can only be applied directly if $n>k$ : otherwise. an error message is printed. For the example in Table $F-2, n=20$ and $k=9$. One possibility for working around this restriction is to use the sampling technique in a piecewise fashion on a subset of the k variables where the number of variables used in each subset is less than $n$. The resulting subsets are then pieced together to form the $n \times k$ input matrix. Such a piecewise approach would ensure the desired correlations among variabies within subsets. but there could exist undesired correlation between variables

belonging to different subsets. In a case such as this, as well as in general, the resulting rank correlation matrix should be examined very carefully to make sure it satisfies the user's requirements. Additionally, in the case that the user does not specify a correlation matrix and does not have $n>k$, the program will generate the desired sample random mixing rather than restricted pairing. Since this approach brings up the possibility of unwanted correlations, the resulting correlation matrix should again be examined very carefully.

As a final note, if the input correlation structure is such that the rank correlation matrix is not a positive definition matrix, an iterative scheme (Iman and Davenport 1982) built into the program will attempt to adjust the input rank correlation matrix to make it positive definite. In this case. a message is printed out along with the adjusted matrix indicating that an adjustment has been made and requesting the user to examine the adjusted matrix to see if it still satisfies the correlation requirements.

\section{RANDOM PAIRING}

Use of this keyword allows the sampled values to be paired randomly. If this keyword does not appear. then the restricted pairing technique of Iman and Conover (1982a) is used subject to the restrictions mentioned under the keyword CORRELATION MATRIX. In the event the user mistakenly includes both the keywords RANDOM PAIRING and CORRELATION MATRIX in the same run, the program will continue to execute; however, the former keyword is ignored with a message to that effect printed after the correlation matrix.

\section{OUTPUT}

This keyword is followed by one or more of three additional keywords. These additional keywords can appear in any order (separated by blanks). Their purpose is to control the amount of printed output. These keywords function as follows:

CORR - Both the raw and rank correlation matrices associated with the actual sample generated are printed. 
HIST - Histograms are generated for each variable in the sample based on the actual values of each variable in the sample.

DATA - If this option is specified, each complete sample ( $n$ observations on $k$ variables) will be listed, followed by a complete listing of the ranks of each variable. Use of this option makes the individual sample input vectors available to the user.

The remaining keywords (at least one of which is required) allow the user to specify the distribution and corresponding parameters for each of the variables in the sample. Eight distributions providing a great deal of flexibility are supplied by the computer program. However. use of a ninth keyword allows for a user-supplied subroutine to be called in order to generate other types of distributions. This subroutine can also be used to obtain samples from empirical data by using the corresponding empirical distribution function. Such a user-supplied subroutine can easily be coded so that it can be called more than once in order to generate different distributions for different variables. For each of the keywords given below additional information describing the variable can be placed as a comment immediately after the trailing blank at the end of the keyword (see the examples on lines $6,8,10,12,14,16,18,20$, and 22 of Table F-2). Such information becomes part of the computer printout and is useful for reference. Each keyword must be followed by at least one additional line of information parameters of the distribution. The only possible exception is the keyword USER DISTRIBUTION where additional information is user-dependent. The number of times these keywords can be repeated is limited only by the dimensions in the program. The program is currently dimensioned to allow for 50 variables but is easily modified.

NORMAL

The second line of information associated with this keyword supplies, in order. the .001 quantile and .999 quantile of the desired normal distribution. See line 7 of Table F-2 where these quantiles are respectively specified as 12 and 56.

\section{LOGNORMAL}

The two parameters specified on the second line have the restriction that both must be positive. Again, these two parameters are defined as the .001 quantile and the .999 quantile. See line 9 of Table F-2 where these quantiles are specified as .01 and 2.13 respectively.

\section{UNIFORM}

The second line of information provides, in order, the lower and upper endpoints of the interval that is to be sampled uniformly. See line 11 of Table F-2 where a uniform distribution is defined on the interval from 1 to 3 . 
WHC-SD-WM-ER-548 Rev. 0

\section{LOGUNIFORM}

This distribution allows the variable to be sampled uniformly on the logarithms base 10 of the two positive parameters supplied on the second line of information. For example. on line 13 of Table F-2. the values $6.0 \mathrm{E} 7$ and $8.1 \mathrm{E} 10$ are specified. The first step in the program is to find the base 10 logarithms of each of these values. These values are respectively 7.78 and 10.91 . Next, a uniform distribution is generated on the interval 7.78 to 10.91 . The last step is to find the antilogarithms of each of the latter values, i.e., $10^{x}$. This scheme allows "uniform" sampling of variables on a logarithmic scale.

\section{UNIFORM*}

Use of this keyword allows for the samples from uniform distributions to be modified by changing the frequency with which uniform sampling is done within subintervals of the range of the variable. Thus. at least one additional line of information is required to allow different subintervals of a given interval to be sampled with frequencies other than what a strictly uniform distribution would provide. The first bit of information indicates the number of subintervals $\mathrm{m}$. followed by $\mathrm{m}$ values indicating the frequency of sampling within each subinterval. Currently. the maximum number of subintervals permitted is 50. The sum of these frequencies must be equal to NOBS and each frequency must be greater than or equal to zero. The last information provides the endpoints of the subintervals in increasing order. For example, on line 15 of Table F-2. rather than having 20 observations obtained uniform $7 y$ on the interval from 1 to 4 , the first number indicates that three subintervals are to be used. Next, the frequencies of sampling for these intervals are to be 5,6 . and 9. (Note that, in general, the sum of these frequencies is NOBS.) Finally, the endpoints of the subintervals are 1 and 2,2 and 3 , and 3 and 4. Thus, five observations are sampled according to a uniform distribution on the interva? from 1 to 2. six observations are sampled according to a uniform distribution on the interval from 2 to 3 , and finally, nine observations are sampled according to a uniform distribution on the interval from 3 to 4 .

\section{LOGUNIFORM*}

This keyword applies to the loguniform distribution in exactly the same way as UNIFORM* does to the uniform distribution.

\section{TRIANGULAR}

This keyword requires an additional line of information containing three values, $a, b$. and $c$. The value $b$ is the $x$-coordinate of the apex of the triangular distribution while a and $c$ are the endpoints of the range. The program allows for $a<b<c$ or $a=b<c$ or $a<b=c$. In the case of $a=b$. the triangular distribution could be generated with the BETA keyword and $p=1$ and $q=2$. Also. for $b=C$. the triangular distribution can be generated with $p=2$ and $q=1$ from the beta distribution. Properties of the triangular distribution are given in the next section. 


\section{WHC-SD-WM-ER-548 Rev. 0}

The second line of information accompanying this keyword contains two values $A$ and $B$ specifying the endpoints of the distribution followed by two shape parameters $p$ and $q$. The shape parameters are described in detail in the code manual (Iman 1984) along with figures illustrating the effect of different choices of $p$ and $q$.

USER DISTRIBUTION

This keyword allows the user to modify a subroutine provided in the code manual (Iman 1984) one or more times in order to generate samples from distributions other than those supplied by the program. Three examples are given in Section 4 of the code manual (Iman 1984) to illustrate multiple uses of this option.

\section{F.6.0 ADDITIONAL INFORMATION ON DISTRIBUTIONS SUPPLIED BY THE COMPUTER PROGRAM}

In the manual for the LHS code (Iman 1984), a more detailed discussion is provided on each of the distributions that are built into the computer program. 
WHC-SD-WM-ER-548 Rev. 0

\section{REFERENCES}

Iman. R.L. and J.C. Helton. 1987. A Comparison of Uncertainty and Sensitivity Analysis Techniques for Computer Models. In preparation.

Iman. Ronald L. and Michael Shortencarier, 1984, A FORTRAN 77 Program and User's Guide for the Generation of Latin Hypercube and Random Samples for Use with Computer Models", NUREG/CR-3624. Sandia National Laboratories.

Iman. R.L. and J.C. Helton. 1983. A Comparison of Uncertainty and Sensitivity Analysis Techniques for Computer Models. In preparation.

Iman. R.L. and W.J. Conover, 1982a. A Distribution-Free Approach to Inducing Rank Correlation Among Input Variables. Communication in Statistics. B11(3), pg. 311-334.

Iman. R.L. and W.J. Conover, 1982b. Sensitivity Analysis Technicques: Self-Teaching Curriculum. Nuclear Regulatory Commission Report, NUREG/CR-2350, Technical Report SAND81-1978. Sandia National Laboratories. Albuquerque, New Mexico

Iman, R.L. and J.M. Davenport, 1982. An Iterative Algorithm to Produce a Positive Definite Correlation Matrix from an "Approximate Correlation Matrix" (With a Program User's Guide), Technical Report SAND81-1376. Sandia National Laboratories. Albuquerque, New Mexico.

Iman, R.L., J.C. Helton, and J.E. Campbe17, 1981a, An Approach to Sensitivity Analysis of Computer Models. Part 1. Introduction. Input Variable Selection and Preliminary Variable Assessment, Journal of Quality Technology, 13(3), pg. 174183.

Iman, R.L.. J.C. Helton, and J.E. Campbel1, 1981b. An Approach to Sensitivity Analysis of Computer Models. Part 2, Ranking of Input Variables, Response Surface Validation. Distribution Effect and Technique Synopsis. Journal of Quality Technology, 13(4). pg. 232-240.

Iman, R.L.. J.M. Davenport, and D.K. Zeigler, 1980, Latin Hypercube Sampling (Program User's Guide). Technical Report 5AND79-1473. Sandia National Laboratories. Albuquerque. New Mexico.

McKay, M. O., W.J. Conover, and R.J. Beckman, 1979, A Comparison of Three Methods for Selecting Values of Input Variables in the Analysis of Output from a Computer Code. Technometrics. 21, pg. 239-245

Marquardt. D.W. and R.D. Snee. 1975. Ridge Regression in Practice, The American Statistician, 29(1), pg. 3-20.

Marquardt. D.W. . 1970. Generalized Inverses, Ridge Regression, Biased Linear Estimation, and Nonlinear Estimation. Technometrics. 12(3). pg. 591-612. 


\section{WHC-SD-WM-ER-548 Rev. 0 \\ REFERENCES (cont'd)}

Steck, G.P., R.L. Iman, and D.A. Dahlgren, 1976. Probabilistic Analys is of LOCA, Annual Report for FY1976. Technical Report SAND76-0535 (NUREG 766513). Sandia National Laboratories. Albuquerque. New Mexico. 
WHC-SD-WM-ER-548 Rev. 0

This page intentionally left blank. 
WHC-SD-WM-ER-548 Rev. 0

APPENDIX G

GENERAL DESCRIPTION OF SIMAN

G-1 
WHC-SD-WM-ER-548 Rev. 0

This page intentionally left blank. 


\section{Genera1 Description of SIMAN}

The risk-based model was developed using the SIMAN (Simulation Analysis) discrete event simulation language from which process and/or event-oriented models can be built. The SIMAN language is coded in two separate files - - the experiment file and the model file. The experiment file contains the variable and logic-element declarations with their default values, if any. The model file contains the logic structures directing the flow of abstract "entities. " which control the occurrence of physical events having associated time durations. The model is constructed in sets of command-lines called blocks that can branch entities, assign values, seize resources, and delay entities based on process durations and logic.

SIMAN originated in the manufacturing field where discrete operations are performed on discrete parts or pieces moving through a complex assembly system. Such a system is accurately represented by discrete changes in the processing state. Within TWRS, both discrete and continuous processes occur, yet transfers or waste additions are practically formalized as a number of discrete transfer or processing events.

SIMAN was developed by Dennis Pegden in 1982 and is developed, maintained, and distributed by Systems Modeling Corporation in Sewickley. Pennsylvania. 
WHC-SD-WM-ER-548 Rev. 0

This page intentionally left blank. 
WHC-SD-WM-ER-548 Rev. 0

APPENDIX H

GENERAL DESCRIPTION OF RANKING SYSTEM 
WHC-SD-WM-ER-548 Rev. 0

This page intentionally left blank. 


\section{General Description of Ranking System}

An expert system was used previously to rank the importance of the output variables from a complex computer model for which the input samples had been created by the Latin Hypercube Sample (Zimmerman 1990 and Russell 1988). The process results were represented in hierarchical trees with the more important variables at the top of the trees.

When the process was fully understood it was found that the expert system code being used could process only 30 independent variables (Thomas and Hapgood. 1989). A Fortran code was then written to duplicate the results of the expert system. A flow chart depicting the working of this code, named MAXWELL, follows, and a listing is given at the end of this appendix.

As indicated in Section 1.3.4 the new code. MAXWELL. was verified by exactly matching the results of a 16 variable run set with the results from the commercial code used by Zimmerman (1990). 
WHC-SD-WM-ER-548, Rev. 0

Figure H-1. Top Level Flow Chart for Program Maxwell

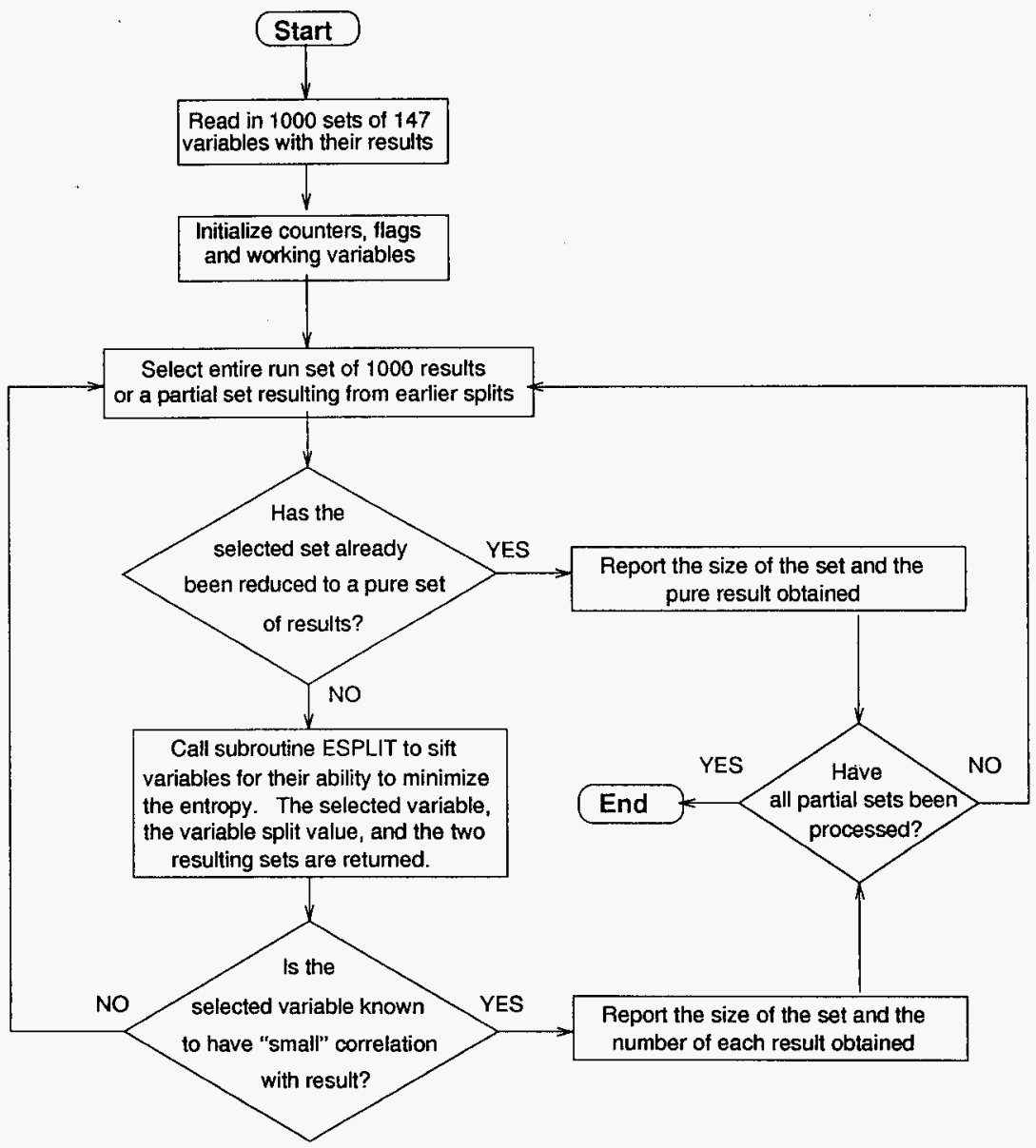




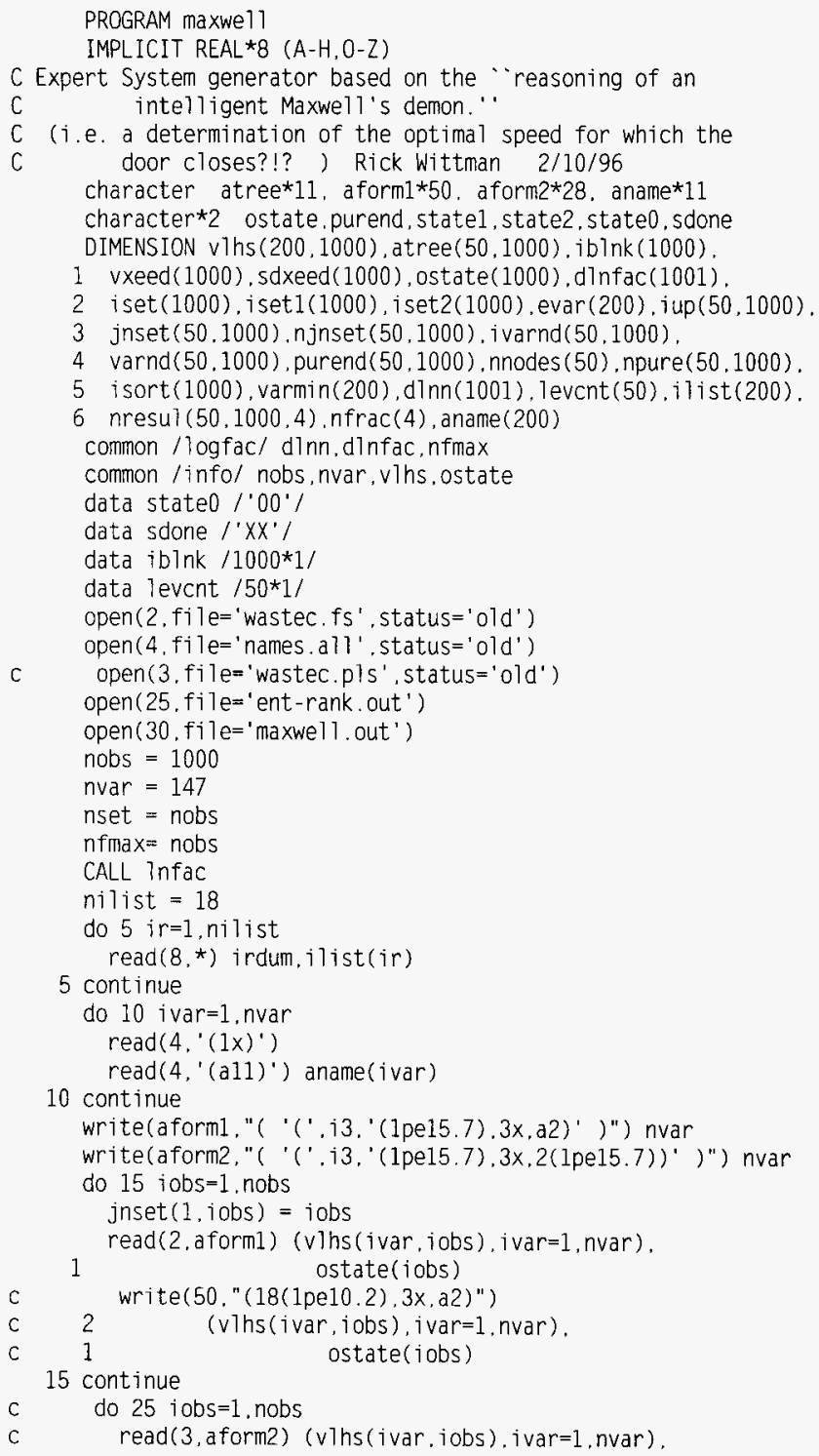




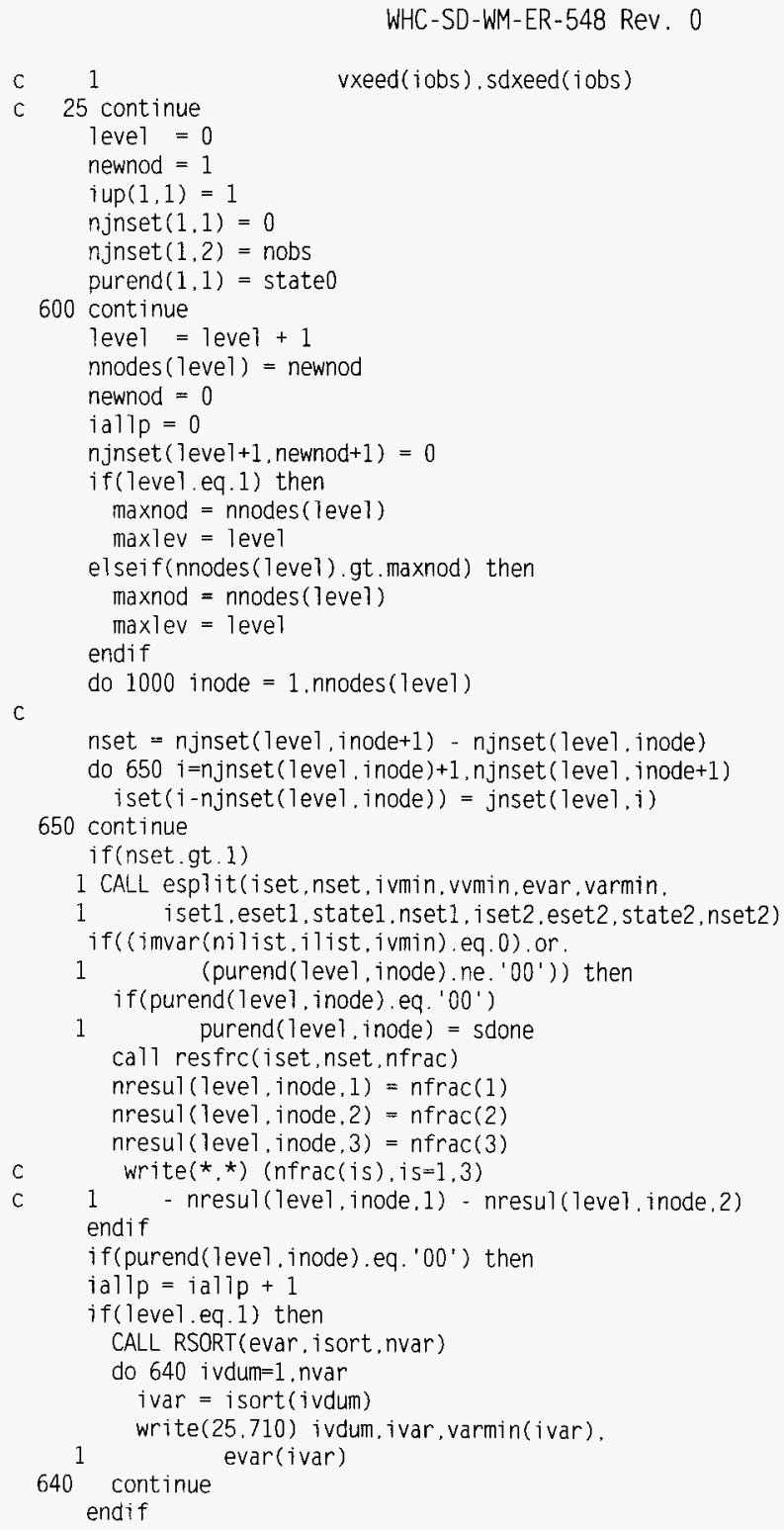


$\begin{array}{ll}\text { ivarnd (level, inode) } & =\text { ivmin } \\ \text { varnd (level, inode) } & =\text { vvmin }\end{array}$

newnod $=$ newnod +1

i up ( leve $1+1$, newnod $)=$ inode

purend (level +1 , newnod) = statel

njnset $($ leve $1+1$, newnod +1$)=\operatorname{njnset}($ leve $1+1$, newnod $)+$ nset 1

do $670 i=$ junset ( leve $1+1$, newnod $)+1$, njnset (level +1 , newnod +1 )

jnset $(1$ eve $1+1, i)=i \operatorname{set} 1(i-\operatorname{njnset}(1$ eve $1+1$, newnod $))$

670 continue

newnod $=$ newnod +1

iup (level +1 , newnod $)$ = inode

purend $($ level +1 , newnod $)=$ state 2

njnset $($ level +1 , newnod +1$)=\operatorname{njnset}(1$ eve $1+1$, newnod $)+$ nset 2

do $680 i=n j n s e t(1$ eve $1+1$, newnod +1 , njnset (level +1 . newnod +1 )

680 continue

jnset $($ leve $1+1, i)=i \operatorname{set} 2(i-n j n s e t(1$ eve $1+1$, newnod $)$ )

else

newnod $=$ newnod +1

iup $(1$ eve $1+1$, newnod $)=$ inode

purend $(1$ evel +1 , newnod $)=$ purend $(1$ eve 1 , inode $)$

njnset (level +1 , newnod +1$)=\operatorname{njnset}(1$ eve $1+1$, newnod $)+$ nset

do $690 i=$ njnset $(1$ eve $1+1$, newnod $)+1$, njnset ( 1 eve $1+1$, newnod +1 )

jnset $($ leve $\rceil+1, i)=i \operatorname{set}(i-$ njnset $(1$ eve $1+1$, newnod $)$ )

690 continue

npure (level, inode $)=$ nset

endif

1000 continue

if (iallp.ne.0) then

goto 600

endif

nlevel $=$ level

c Poor man's Tree Output

do 1400 leve $=$ nlevel $, 1,-1$

inode $=0$

do $1400 i=1$, maxnod

if(iblnk(i).eq. 1) then

inode $=$ inode +1

if (purend( level. inode). ne.state0) then

write(atree (level, $2 \star i-1), 705$ )

write(atree( level, 2*i),720)

1 purend (level, inode), npure (level, inode)

c 2 (nresul( 1evel:inode, is), is=1,3)

c 1 purend (level, inode). npure (level, inode)

if ( (purend (level, inode) . eq atree (level $+1.2 * i)(5: 6)$ )

1 and. (level ne.nlevel))

2 write(atree (level $+1,2 * i) .705)$

else

write(atree(level, $2 * i-1), 730$ ) ivarnd(level,inode)

write(atree (level,2*i),740) varnd(level, inode) 


\section{WHC-SD-WM-ER-548 Rev. 0}

endif

if ( (iup (level, inode). eq. iuplast). and. (inode.gt.1)) then iblnk $(i)=0$

endif

iuplast $=$ iup( level, inode)

else

write (atree ( level, $\left.2 \star_{i}-1\right), 705$ )

write(atree (level, $2 \star i$ ) , 705)

endif

1400 continue

do 1500 level=nlevel $, 2,-1$

$i$ find $=0$

do $1500 i=2 \star^{*} \operatorname{maxnod}, 1,-1$

if (ifnd.eq.1) then

if( atree(level,i).eq.' ' ) then

write(atree(level, i) , 750)

else

ifnd $=0$

endif

endif

if( (atree(level,i).ne.' '). and.

1 (atree (1evel-1,i).eq.' ') ) ifnd $=1$

1500 continue

do $2000 i=1$, maxnod

write $\left(30,{ }^{\prime}(50 a 11) '\right)$ (atree (1eve 1.2*i-1). level=1, nlevel)

write(30. '(50a11)') (atree( level.2*i), level=1, nlevel)

2000 continue

write $(*, 760)$

1 aname (ivarnd $(1,1)$ ). $\operatorname{varnd}(1,1)$

do 3000 in $2=1,2$

if(ivarnd (2, levent(2)). ne.0) then

write $(*, 760)$

1 aname(ivarnd(2, 1evcnt (2))), varnd(2, levcnt(2))

else

write $(* .725)$ (nresul (2. 1event(2), is), is $=1,3)$

write(*.' (4x, "nu11")')

endif

levent (2) $=$ levent (2) +1

if (ivarnd (2, levent (2)-1) ne. 0) then

do 2990 in $3=1.2$

if (ivarnd (3, levent(3)). ne.0) then

write $(*, 760)$

1 aname(ivarnd(3, levcnt(3))), varnd(3, levcnt(3))

else

write(*.725) (nresul (3, levcnt(3), is), is $=1,3)$

write(*, ' (4x, "nul1")')

endif

levent (3) $=$ levent $(3)+1$

if (ivarnd ( 3, levcnt ( 3$)-1$ ). ne. 0 ) then

do 2980 in $4=1,2$

if (ivarnd(4, levent (4)) ne. 0 ) then 
WHC-SD-WM-ER-548 Rev. 0

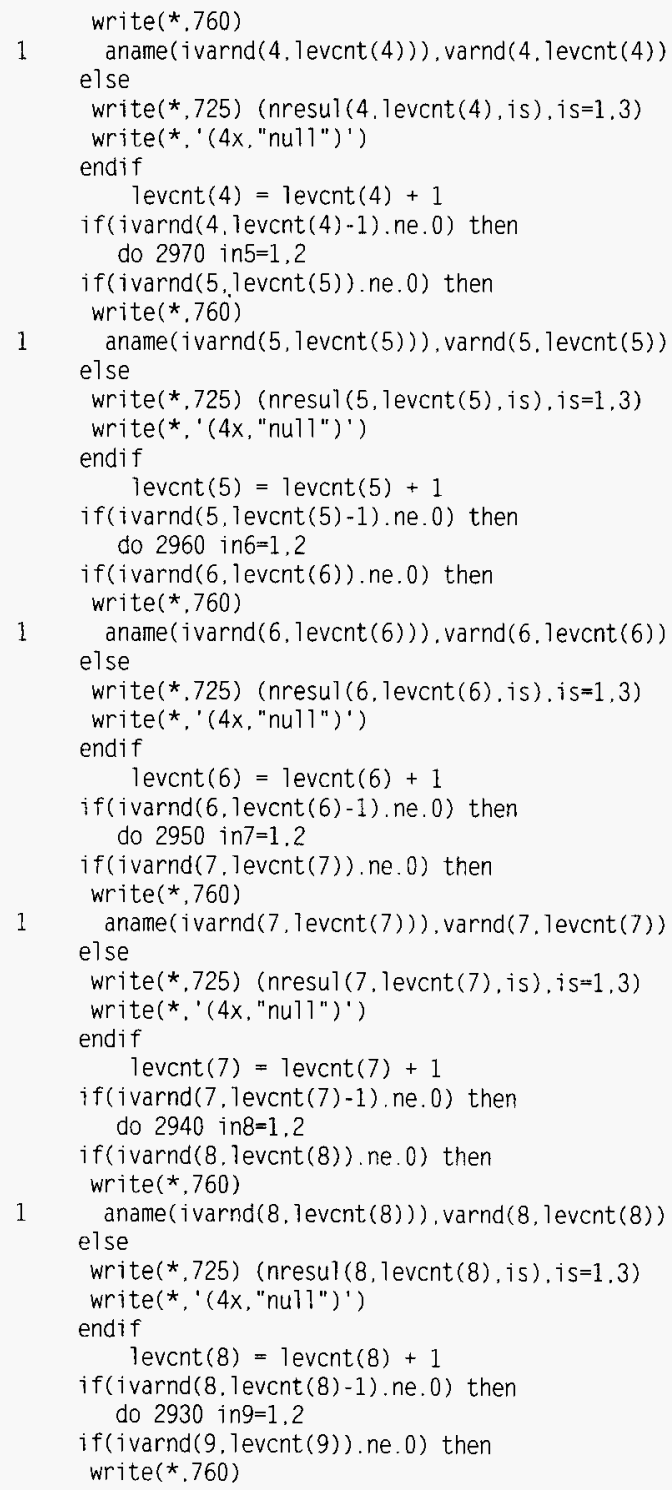




\section{WHC-SD-WM-ER-548 Rev. 0}

1 aname (ivarnd $(9$, levent $(9))$ ), $\operatorname{varnd}(9$, levent $(9)$ )

else

write $(\star .725)$ (nresul $(9$. levent (9), is), is $=1,3$ )

write ${ }^{*}, '(4 x$, "nul1")')

endif

levent $(9)=1$ event $(9)+1$

if (ivarnd (9. levent (9)-1) ne. 0 ) then do 2920 in $10=1.2$

if (ivarnd(10, levcnt (10)). ne.0) then

write $(*, 760)$

1 aname (ivarnd $(10,1$ evcnt (10))), varnd(10, levcnt(10))

else

write $\left.{ }^{*}, 725\right)$ (nresul $(10$, levent $(10)$, is $)$, is $\left.=1,3\right)$

write (*, '(4x, "nu11")')

endif

levent $(10)=\operatorname{levent}(10)+1$

if (ivarnd $(10$, levent $(10)-1)$, ne. 0$)$ then do 2910 in $11=1,2$

if (ivarnd(11, levcnt(11)). ne.0) then

write $(* .760)$

1 aname (ivarnd(11, levcnt(11))), varnd(11, levcnt(11))

else

write $(*, 725)$ (nresul (11, 1event(11), is), is $=1,3$ )

writes*, ' $(4 x$, "nut7")')

endif

levent $(11)=1 \operatorname{evcnt}(11)+1$

if (ivarnd (11, levent (11)-1) ne. 0) then

do 2900 in $12=1.2$

if (ivarnd(12, levcnt (12)). ne.0) then

write $(*, 760)$

1 aname (ivarnd (12. levent(12))), varnd(12, levent(12))

else

write $\left.{ }^{*}, 725\right)$ (nresul (12, levent (12), is), is $=1,3$ )

write ${ }^{*}, '(4 x$, "nul7")')

endif

levent (12) = levent (12) +1

if (ivarnd(12. levent (12)-1) ne. 0) then do 2890 in $13=1.2$

if (ivarnd(13, levent(13)) . ne.0) then

write $(*, 760)$

1 aname (ivarnd(13, levcnt(13))), varnd(13, levcnt(13))

else

write $(*, 725)$ (nresul $(13$, levant $(13)$, is), is $=1,3$ )

write ${ }^{*}, '(4 x$, "rul1")')

endif

levcnt $(13)=1 \operatorname{evcnt}(13)+1$

if (ivarnd(13. levant (13)-1). ne. 0) then do 2880 in $14=1.2$ 


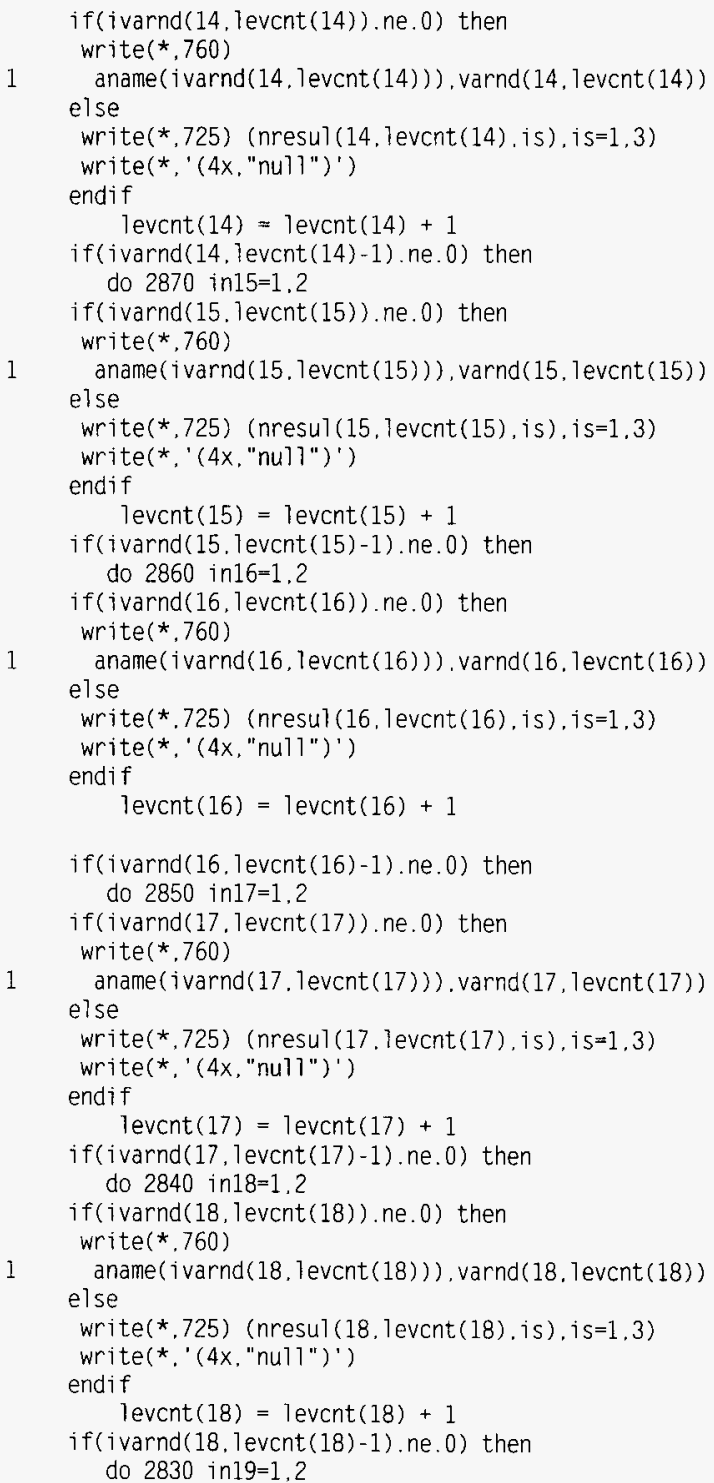




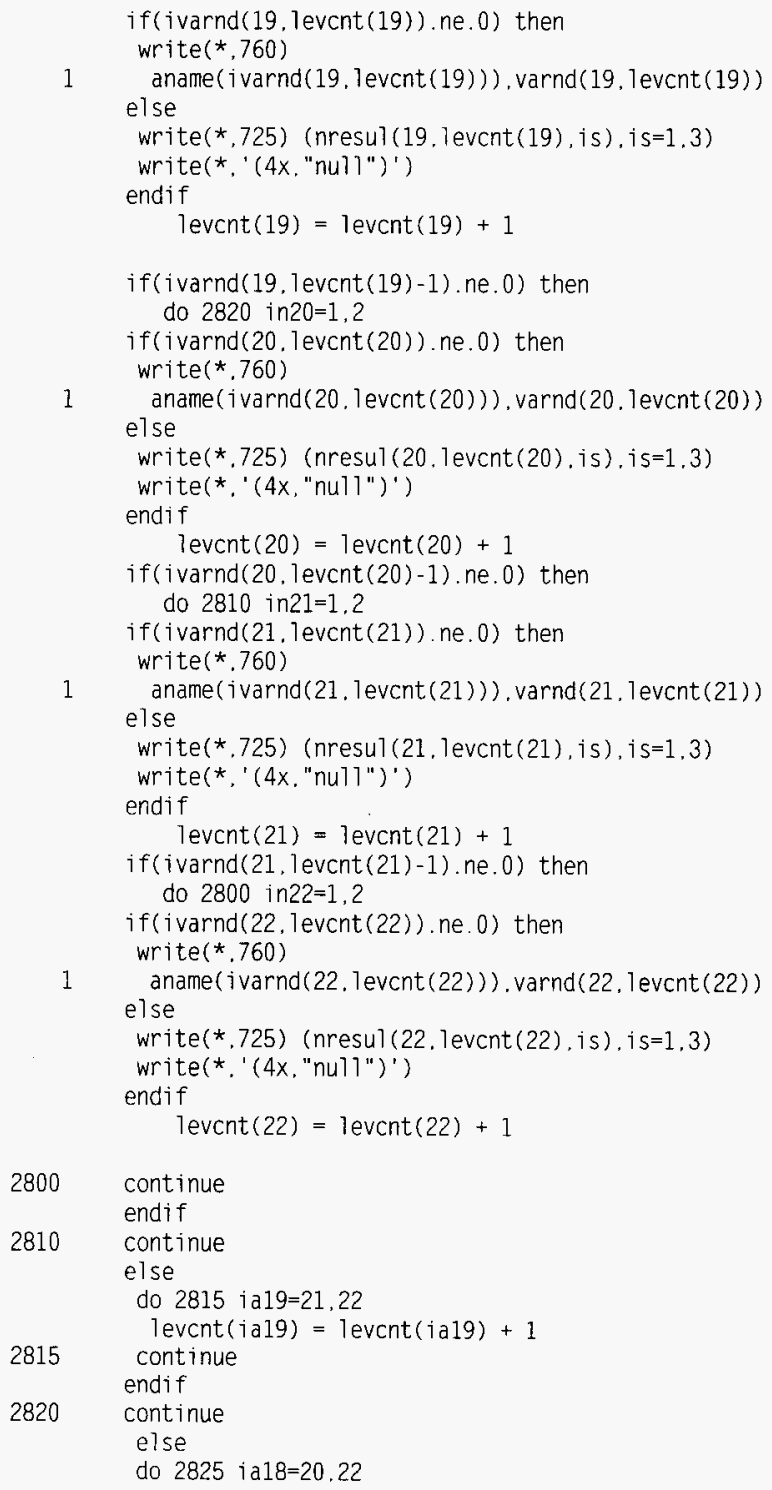




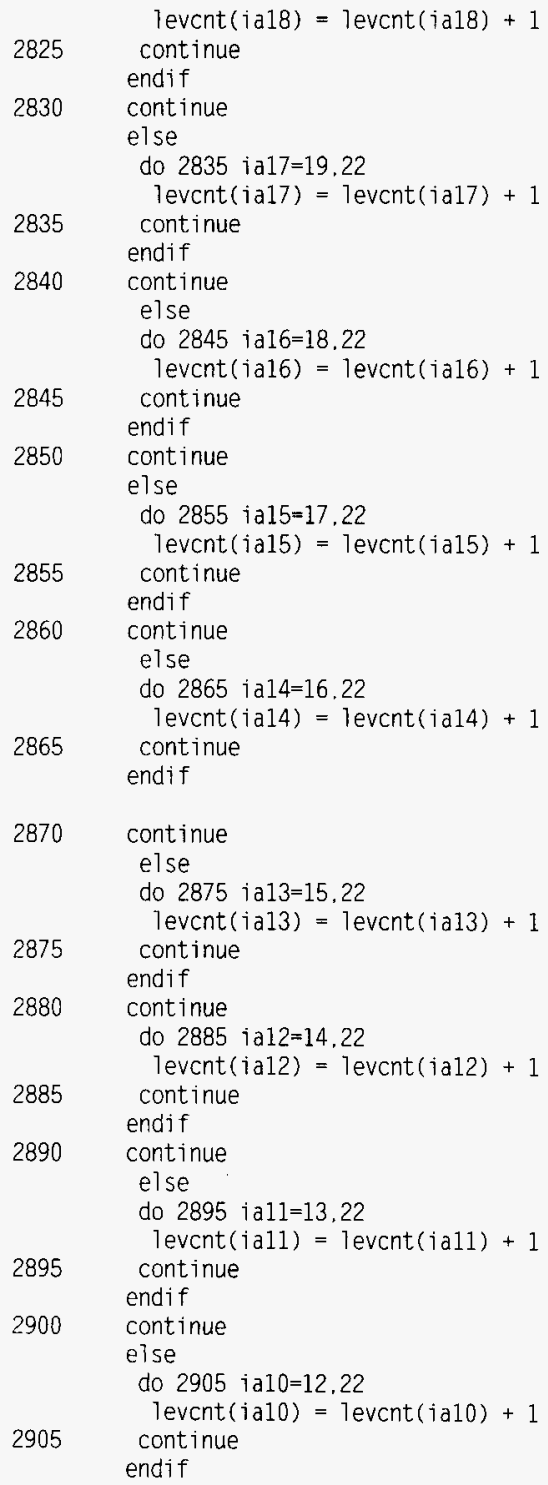


WHC-SD-WM-ER-548 Rev. 0

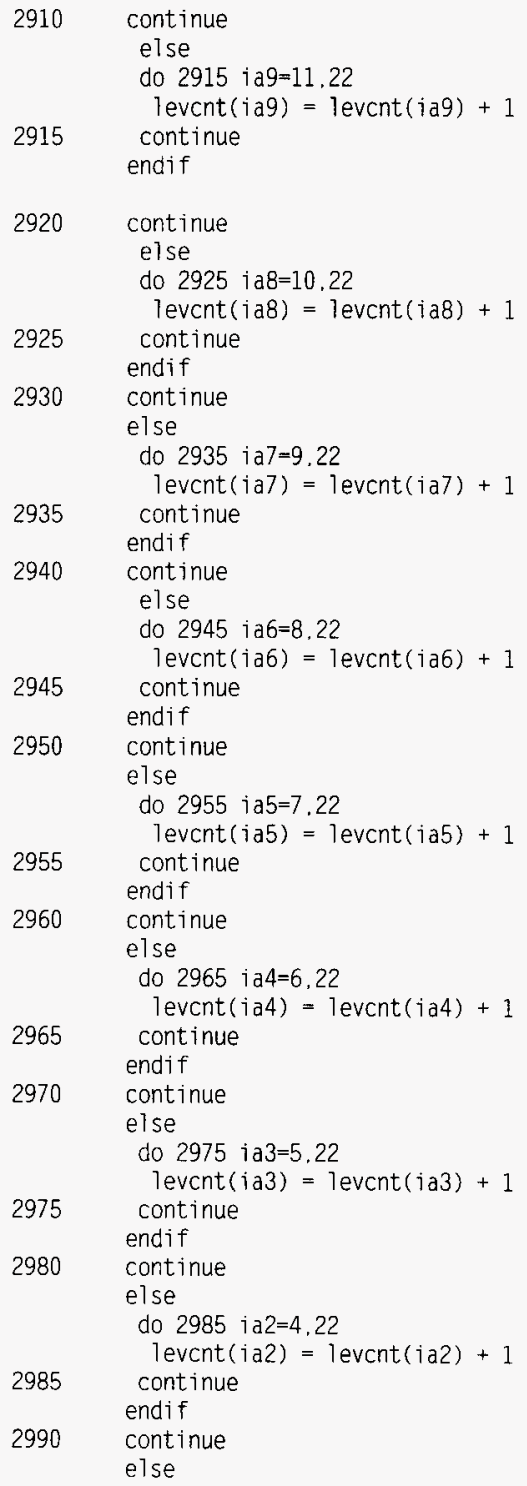


WHC-SD-WM-ER-548 Rev. 0

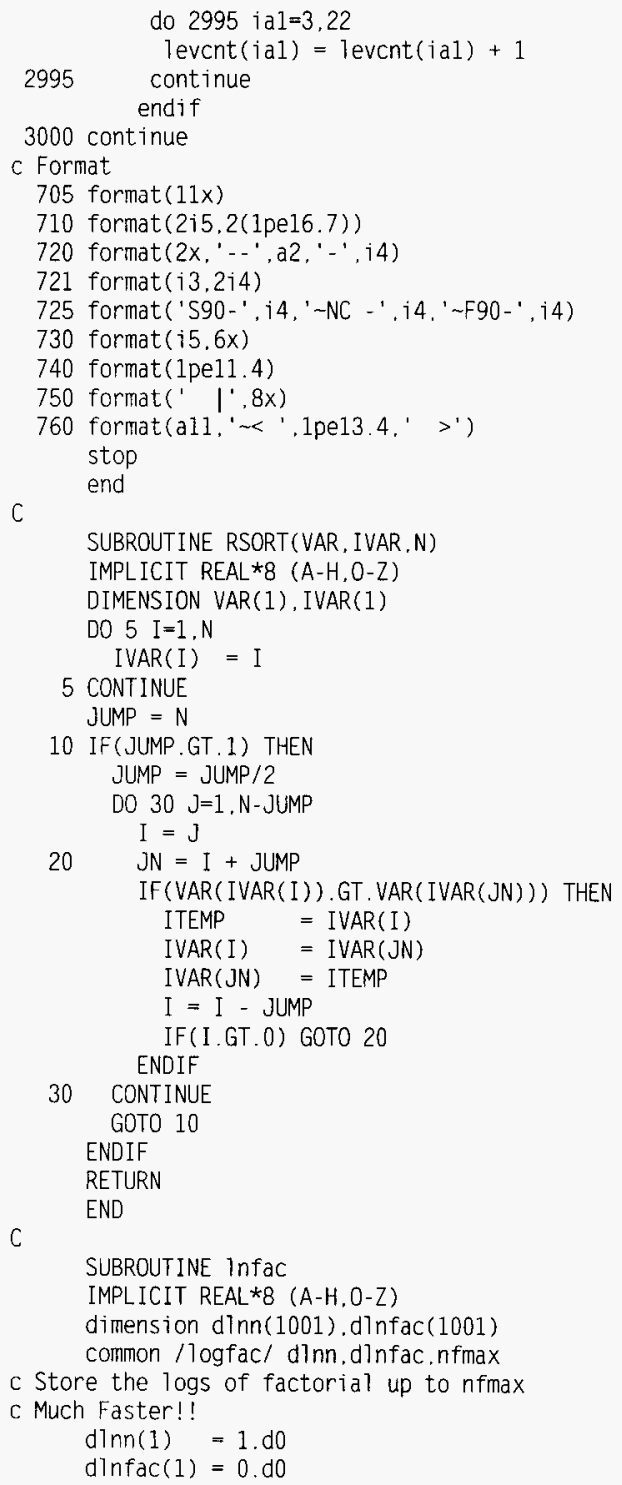


do $10 i=1, n f \max$

$$
\begin{aligned}
& \operatorname{dlnn}(i+1)=\operatorname{dlog}(\operatorname{dfloat}(i)) \\
& \operatorname{dlnfac}(i+1)=\operatorname{dlnfac}(i)+\operatorname{dlnn}(i+1)
\end{aligned}
$$

10 continue

return

end

C

FUNCTION imvar( $n$, ilist, jvar)

integer imvar

dimension ilist(1)

imvar $=0$

do 10 jlook=1, n

if( ivar.eq.ilist (ilook) ) imvar $=1$

10 continue

return

end

C

FUNCTION d7fac(n)

IMPLICIT REAL*8 (A-H, O-Z)

real*8 d 1 fac

dimension dinn(1001), dinfac(1001)

common /logfac/ dlnn, dlnfac.nfmax

$\mathrm{dlfac}=\operatorname{dinfac}(n+1)$

return

C

end

FUNCTION $\operatorname{dln}(n)$

IMPLICIT REAL $\star 8(A-H, 0-Z)$

real*8 d $7 n$

dimension dlnn(1001), dlnfac(1001)

common /logfac/ dlnn, dlnfac, nfmax

$d ? n=d l n n(n+1)$

return

end

C

FUNCTION entp2(n1,n2)

IMPLICIT REAL*8 (A-H.O-Z)

rea $7 * 8$ entp2

$n=n 1+n 2$

$C$ compute entropy $x$ population

entp2 = dlfac (n)-d1fac (n1)-d1 fac (n2)

return

end

FUNCTION entp4(n1,n2,n3,n4)

IMPLICIT REAL *8 (A-H, O-Z)

rea $7 * 8$ entp4

$n=n 1+n 2+n 3+n 4$

$c$ compute entropy $x$ population

c entp4 $=\operatorname{dlfac}(n)-d 1 f a c(n 1)-d 1 f a c(n 2)-$

c 1 dlfac $(n 3)-d 1 f a c(n 4)$ 


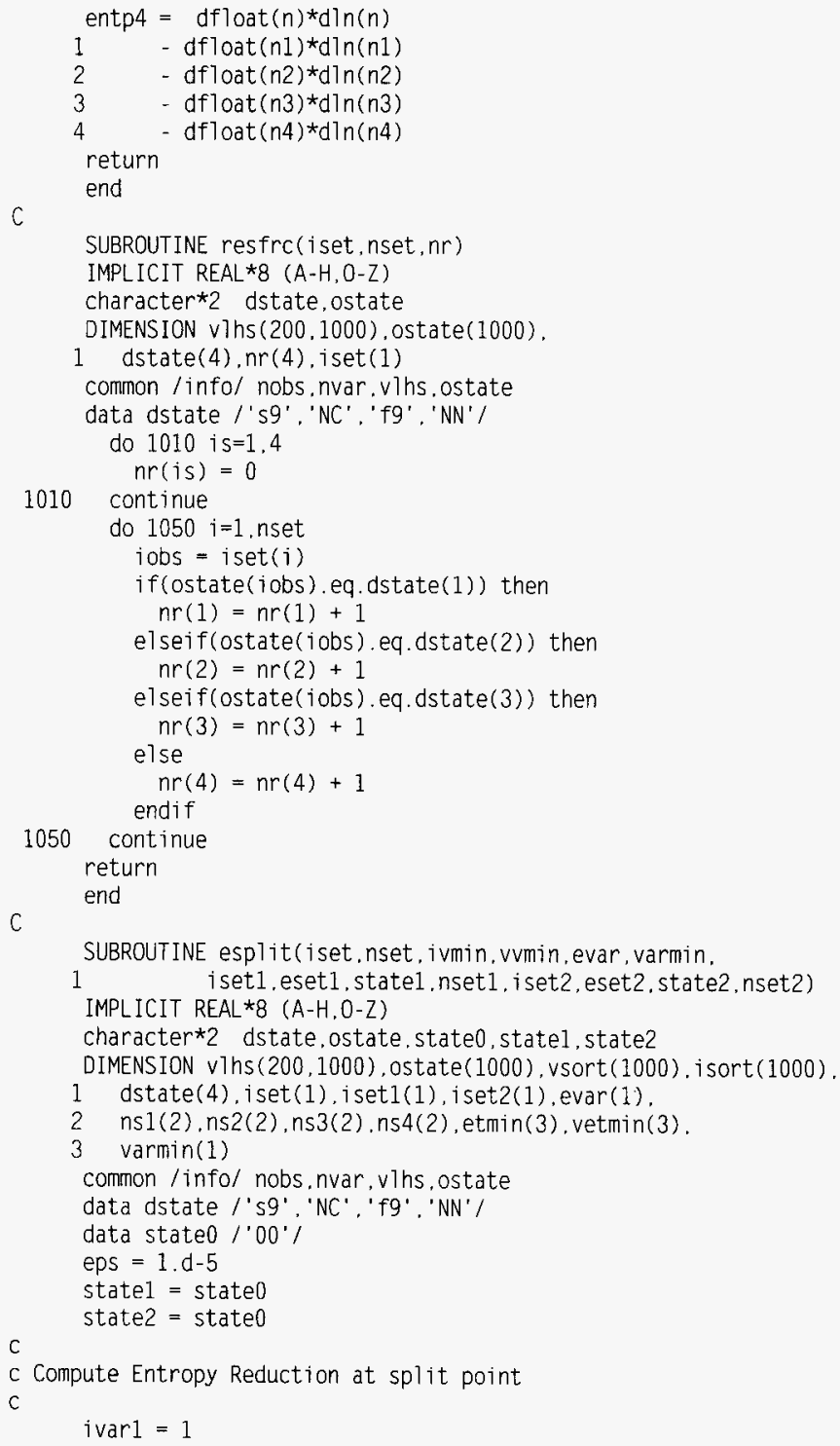


WHC-SD-WM-ER-548 Rev. 0

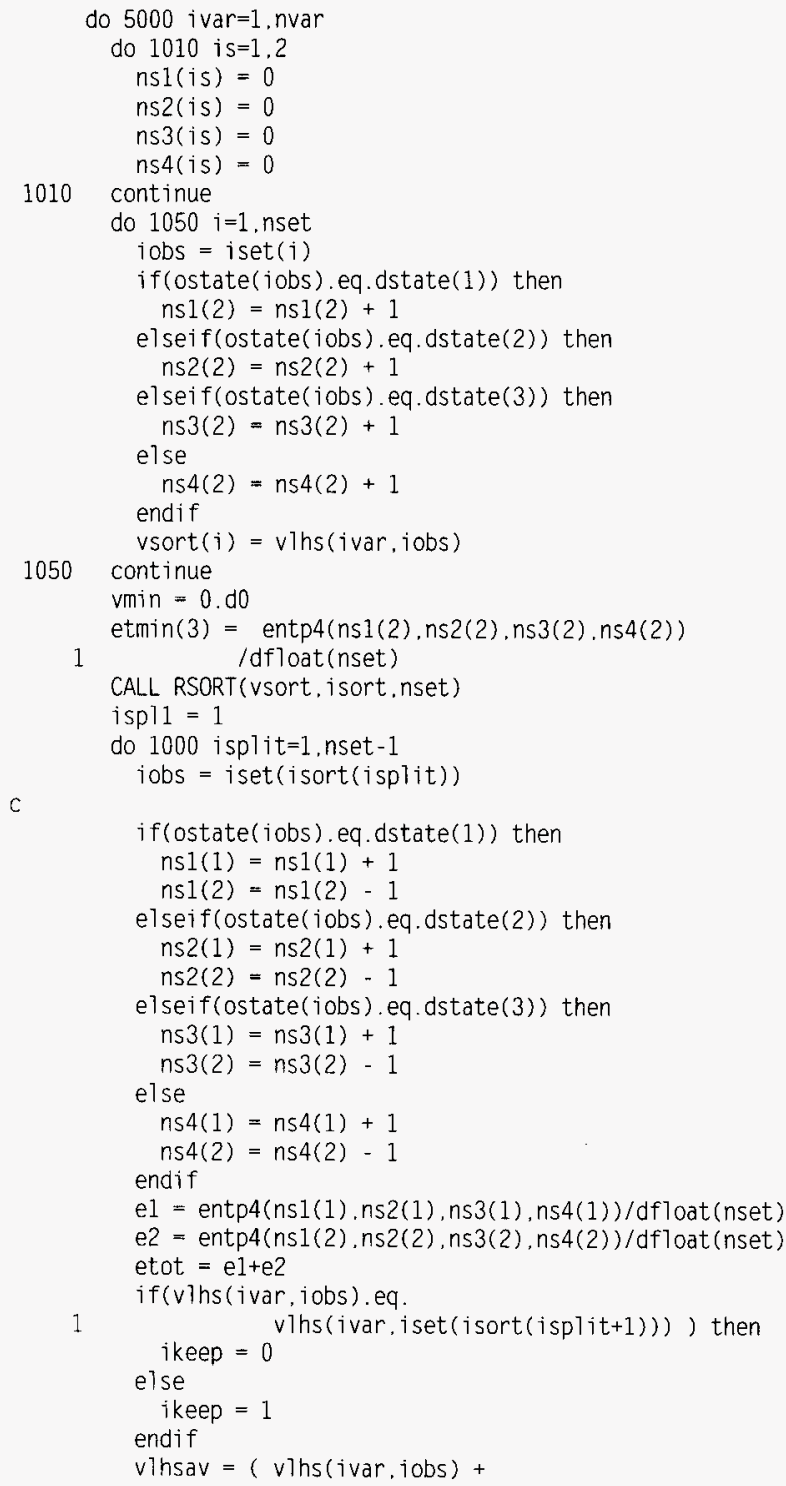




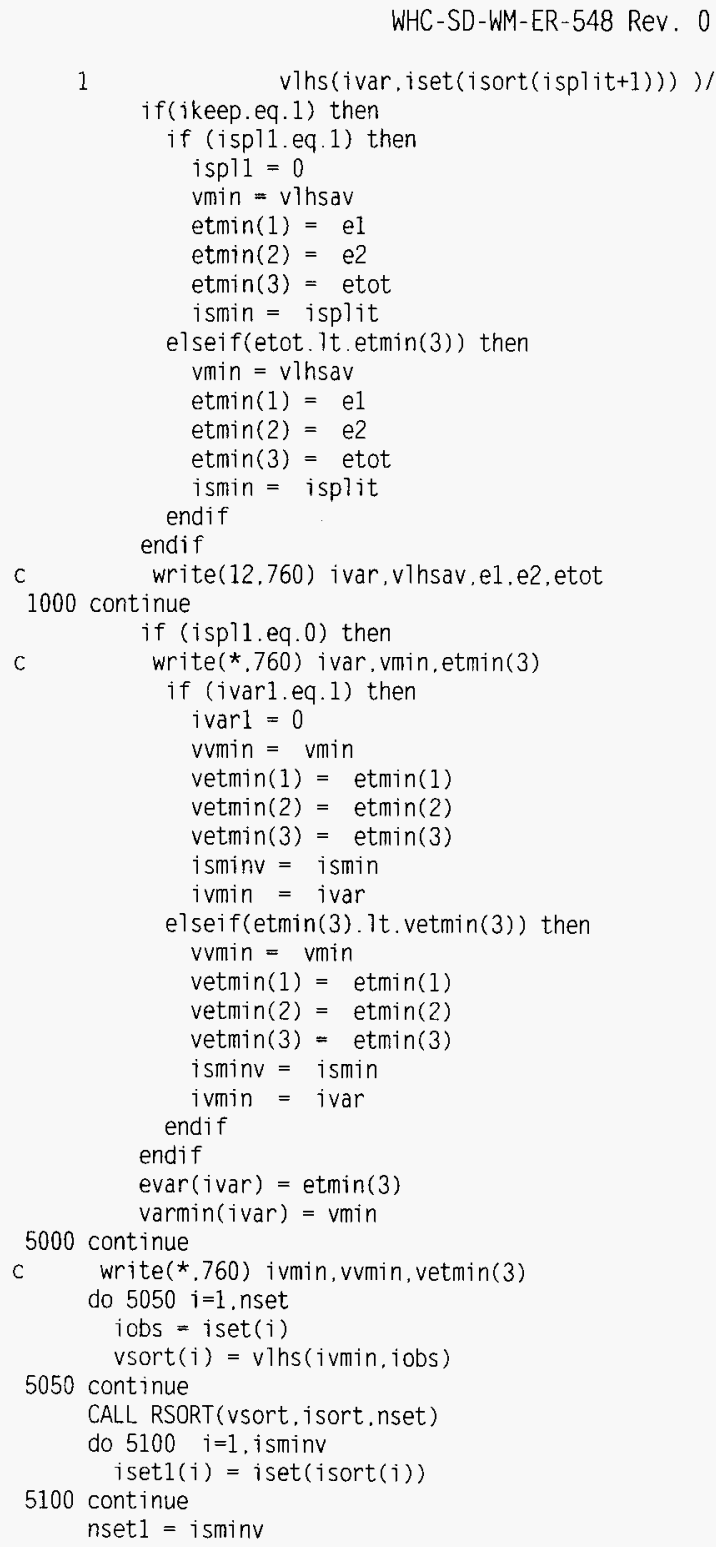


WHC-SD-WM-ER-548 Rev. 0

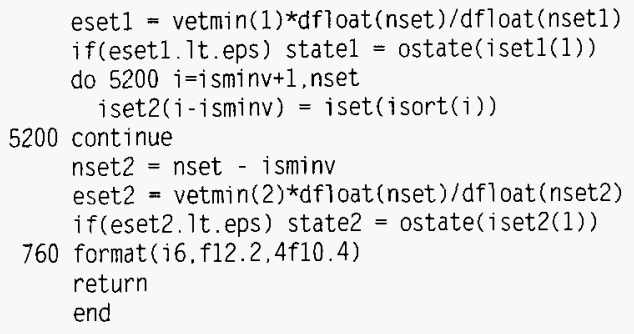




\section{WHC-SD-WM-ER-548 Rev. 0 \\ REFERENCES}

Thomas, W. and Wi11 Hapgood, 1989. 1st Class Expert Systems, Inc. Manua?. 
WHC-SD-WM-ER-548 Rev. 0

This page intentionally left blank. 


\section{DISTRIBUTION SHEET}

\begin{tabular}{|c|c|c|c|c|c|}
\hline \multirow{2}{*}{$\begin{array}{l}\text { To } \\
\text { Distribution }\end{array}$} & \multirow{2}{*}{\multicolumn{3}{|c|}{$\begin{array}{l}\text { From } \\
\text { TWRS Technical Integration }\end{array}$}} & \multicolumn{2}{|l|}{ Page 1 of 1} \\
\hline & & & & \multicolumn{2}{|c|}{ Date $09 / 27 / 96$} \\
\hline \multirow{2}{*}{\multicolumn{4}{|c|}{$\begin{array}{l}\text { Project Title/Work Order } \\
\text { Sensitivity Analysis } \\
\text { Shell Tank System and }\end{array}$}} & \multicolumn{2}{|c|}{ EDT No. 615723} \\
\hline & & & & \multicolumn{2}{|l|}{ ECN No. } \\
\hline \multicolumn{2}{|l|}{ Name } & $\begin{array}{l}\text { Text } \\
\text { With All } \\
\text { Attach. }\end{array}$ & Text Only & $\begin{array}{l}\text { Attach./ } \\
\text { Appendix } \\
\text { Only }\end{array}$ & $\begin{array}{c}\text { EDT/ECN } \\
\text { Only }\end{array}$ \\
\hline $\begin{array}{l}\text { N. G. Awadalla } \\
\text { W. B. Barton } \\
\text { J. F. Best } \\
\text { D. J. Francis } \\
\text { J. W. Haies (3 copies) } \\
\text { G. Jansen } \\
\text { C. E. Jensen } \\
\text { B. J. Knutson (5 copies) } \\
\text { H. J. Stafford, Jr. } \\
\text { H. J. Wacek } \\
\text { R. S. Wittman } \\
\text { B. D. Zimmerman }\end{array}$ & $\begin{array}{l}H 6-35 \\
R 2-11 \\
H 6-35 \\
H 6-51 \\
B 1-17 \\
H 6-35 \\
R 1-55 \\
H 6-35 \\
S 7-53 \\
S 7-54 \\
H 6-35 \\
H 6-35\end{array}$ & $\begin{array}{l}x \\
x \\
x \\
x \\
x \\
x \\
x \\
x \\
x \\
x \\
x \\
x\end{array}$ & & & \\
\hline Central Files & A3-88 & $x$ & & & \\
\hline
\end{tabular}

